Portland State University

PDXScholar

Spring 1-1-2012

\title{
Engaging Community Food Systems through Learning Garden Programs: Oregon Food Bank's Seed to Supper Program
}

Denissia Elizabeth Withers

Portland State University

Follow this and additional works at: https://pdxscholar.library.pdx.edu/open_access_etds

Part of the Agriculture Commons, Educational Leadership Commons, and the Educational Methods Commons

Let us know how access to this document benefits you.

\section{Recommended Citation}

Withers, Denissia Elizabeth, "Engaging Community Food Systems through Learning Garden Programs: Oregon Food Bank's Seed to Supper Program" (2012). Dissertations and Theses. Paper 609.

https://doi.org/10.15760/etd.609

This Thesis is brought to you for free and open access. It has been accepted for inclusion in Dissertations and Theses by an authorized administrator of PDXScholar. Please contact us if we can make this document more accessible: pdxscholar@pdx.edu. 
Engaging Community Food Systems through Learning Garden Programs: Oregon

Food Bank's Seed to Supper Program

by

Denissia E. Withers

A thesis submitted in partial fulfillment of the

requirements for the degree of

\section{Masters of Arts}

in

Education: Policy, Foundation and Administration

Thesis Committee:

Heather Burns, Chair

Andrew Job

Lisa H. Weasel

Portland State University

2012 


\begin{abstract}
The purpose of this study was to discover whether learning garden programs increase access to locally grown foods and successfully empower and include food insecure populations. This study examined the Oregon Food Bank's Seed to Supper program which situates garden-based learning in food insecure communities. Through a mixed-methods community-based research process, this study found that community building, learner empowerment and sustainability leadership in placebased learning garden programs increased access to locally grown foods for food insecure populations. When food insecure populations participated in these learning garden programs they often engaged in practices described in the literature as the "web of inclusion" (Helgesen, 1995). When food insecure populations were engaged in these practices, participation in food democracy and food justice increased. Additionally, participation in learning gardens led to sustainability leadership and increased access to food literacy, which led to greater community health and engaged, local community food systems.
\end{abstract}




\section{ACKNOWLEDGEMENTS}

My gratitude goes out to all my family and friends for helping me through the thesis process. I learned how much patience and faith my closest friends, colleagues and family possess, especially my partner, Ray, who deserves special credit for his dutiful and insightful editing.

My mentor, Dr. Lisa H. Weasel, was vital to the research process of this project and helped further my understanding of community-based research and the relationship building needed to see this project through. I will always be grateful for the opportunity to assist her with the Food, Democracy and Sustainability Capstone at several of the research sites. From this opportunity, I learned the fundamentals of community-based learning and the theoretical foundations of food democracy.

It was my adviser Dr. Heather Burns and the Leadership for Sustainability (LSE) course of study that led me to many discoveries about sustainable leadership and spiritual leadership in education. We bonded and created a synergistic partnership that deepened during the process of organizing and preparing my thesis. I am forever grateful for her inspiration, persistence and patience.

I also want to acknowledge Andrew Job for the optimism and sensitivity that he brought to the learning environment and core LSE School of Education courses. I had several epiphanies in his classes that were stimulated by the lectures, readings and the papers; these enhanced my experience and ultimately this paper.

I thank the Seed to Supper participants for taking the time to be interviewed and participate in the survey process. Additionally, I thank the instructors, 
community leaders and research site coordinators for their amazing work addressing food security through learning gardens and other social justice work. And most important, to the community partner, Oregon Food Bank and its program coordinators who assisted in the research process including Rebeca Siplak, Ginny Sorensen and Ali Abbors-thank you all for the community partnership we formed and the work we continue to do.

Many of the LSE cohort listened to me talk about my project and I appreciated the warm collegial atmosphere of the program and the generosity of all those who listened and helped along the way. My deepest gratitude to the following individuals: Dr. Hunter Shobe, Tanya Cheeke, Melissa Pirie, Jon Brown, Jemila Hart, Owen Dailey, Marlene Howell, Lisa Durden, Teri Stoeber, Andres Guzman and the McNair Scholars program staff Dr. Toeutu Faaleava and Jolina Kwong. 


\section{TABLE OF CONTENTS}

$\begin{array}{lll}\text { ABSTRACT } & \text { i }\end{array}$

ACKNOWLEDGEMENTS

LIST OF TABLES viii

LIST OF FIGURES Ix

Chapter 1: Introduction 1

Learning Garden Scene 1: Brookplace: A Growing Learning Garden Community 1 Historic Patterns that have Influenced Food Insecurity and the Rise of Food Banks and Learning Gardens 3

What is Food Insecurity? 3

Agricultural, Economic, and Political Patterns of the Mid-to-Late 20 ${ }^{\text {th }}$ Century 5

1980s-2000s - The Emphasis on Economic Reform Impacts Food $\begin{array}{ll}\text { Security } & 7\end{array}$

The Rise of the Counterculture and its Impact on Food Security 8 The Food Movement of the 2000s: Food Justice, Learning Gardens and Community Food Systems

Rise of Food Banks and Learning Gardens $\quad 11$

Why Study Learning Gardens? 12

The Local Food Movement in the Portland Area: Background for study 14

Oregon Food Bank's Seed to Supper Program 16

Research Questions and Importance of Study 18

Community Based Research 19

$\begin{array}{ll}\text { Overview of Chapters } & 19\end{array}$

$\begin{array}{ll}\text { Chapter 2: Literature Review } & 21\end{array}$

Learning Garden Scene 2: Forest Hills a historic community garden 21

Overview to Literature Review $\quad 21$

Historical Framework for Learning Gardens:

What is a Learning Garden? 23

The goals of Sustainability Education $\quad 25$

Learning Garden Pedagogy 26

Experiential Learning Theory and the Garden $\quad 27$

Place-based Learning in the Garden 30

Food Literacy in Garden-based Learning: A Link to Food Security 32

Ecoliteracy: Concepts of Sustainability in the Garden $\quad 35$

Community Food Security and Food Democracy \& Food Justice 37

$\begin{array}{ll}\text { Conclusion } & 41\end{array}$ 
Learning Garden Scene 3: Interview at Bell Tower Community Center:

Linking up with Community-based Research

Research Study Background and Development of the Community Partner $\quad 45$

Research Questions

Research Design and Rationale: Community-Based Research

Using Mixed Methods

Research Sites

Research Participants $\quad 54$

Data Collection $\quad 58$

Quantitative: Survey Design and Implementation 59

Design \& Sample Questions $\quad 59$

Survey Implementation $\quad 61$

Qualitative: Interview Design and Process 62

Interview Design: The Questions 62

Interview Implementation: Framing the Interviews 64

Participant and Nonparticipant Observation, Notetaking, Journaling and photographic Fieldwork 67

Data Analysis

Qualitative Data $\quad 70$

$\begin{array}{ll}\text { Quantitative Data } & 71\end{array}$

Validity

73

Limitations

74

The Positionality of the Researcher $\quad 75$

Significance \& Conclusion

Chapter 4: Results

Learning Garden Scene 4: A Senior Center with a Focus on

Fresh Locally-grown Foods

$\begin{array}{ll}\text { Introduction to Chapter } 4 & 78\end{array}$

Overview to Research Question $1 \quad 79$

Survey Results: Increased Access to Fresh and Local Foods $\quad 79$

Interview Responses: Increased Access to Fresh and Local Foods 81

Observations and Comments from Researcher Fieldwork

Notes and Photos: Access to Fresh and Local Foods

82

Community Building Leads to Greater Sense of Food Literacy

and Access to Local and Fresh Food

84

Overview to Research Question 2

Place-based Learning and Learner Empowerment:

Foundations of the Seed to Supper Program 92

Place Based Learning $\quad 92$

Learner Empowerment: Building on Success 99 
Overview to Research Question $3 \quad 104$

Barriers to Food Security 105

Cost and Availability of Fruits and Vegetables $\quad 105$

Access to Garden Space $\quad 111$

$\begin{array}{ll}\text { Transportation } & 115\end{array}$

Economic Hardship 119

Overview to Question $4 \quad 123$

Food Literacy 123

Participant Profile: Food Literacy 129

$\begin{array}{ll}\text { Self-Reliance } & 130\end{array}$

Participant Profile: Self-Reliance 133

$\begin{array}{ll}\text { Social Capital } & 134\end{array}$

Perspective of an Engaged Community Food System 134

Site Profile: Lakeview Correctional Facility Learning Garden Project 136

Conclusion

Chapter 5: Discussion, Implications for Practice \& Conclusion 138

Learning Garden Scene 5: Community-Based Learning and Food Democracy 138

Web of Inclusion, Integrated Partnerships and Sustainable Leadership $\quad 140$

Implications, Best Practices and Policy Change 148

1) Programmatic Best Practices for Educators, Including Site Coordinators and

Community Activists

$\begin{array}{lr}\text { Community Building } & 149\end{array}$

Best Practices for Community Building Through Internal Partnerships 149

Experiential Learning: Recommendations 149

Learner Empowerment and Food Literacy in the Garden Education

Curriculum: Recommendations 151

Instructor Training for Enhancing

Learner Empowerment: Recommendations

152

Best Practices for Community Building Through External Partnerships 154

Networking and Community Development: Recommendations 154

Mentorship for Sustainable Leadership: Recommendation $\quad 155$

Best Practices for Encouraging Sustainable Leadership $\quad 157$

Community Education $\quad 158$

Community Events $\quad 159$

1) Programmatic Best Practices for Educators, Including Site Coordinators and

Community Activists $\quad 161$

$\begin{array}{ll}\text { Place-based Learning } & 161\end{array}$

Recommendations for Implementation 163

2) Barriers and Policy Recommendations for Community Leaders and the Public

$\begin{array}{ll}\text { Service Sector } & 167\end{array}$

$\begin{array}{lr}\text { Cost } & 168\end{array}$ 
Recommendations for Policy Change to Reduce the Cost Barriers

- Local (City, County and State) Levels

Recommendations for Policy Change to Increase Access to

Fresh Foods - Federal level

Recommendations for Policy Change for Expansion of

Available Garden Space

173

Transportation

Best Practices and Recommendations for Overcoming

Transportation Barriers

174

Economic Hardship

Citizenship: Pathways to Food Democracy and Food Justice

Implications for Activism: Action and Participation

Benefits of Community-Based Learning

181

Conclusion

182

REFERENCES

APPENDICES

A. OREGON FOOD BANK LEARNING GARDEN SURVEY 


\section{LIST OF TABLES}

1. Seed to Supper Sites for Survey and Fieldwork 53

2. Survey Sites only 54

3. Interview Participant Information - Group 1: Seed to Supper Participants 57

4. Interview Participant Information - Group 2: Seed to Supper Instructors 58

5. Interview Participant Information - Group 3: Community Members and Leaders $\quad 58$

6. Research Questions and Examples of Survey Questions 60

7. Sample Seed to Supper Participant Interview Questions Linked to Research Questions

8. Community Members/Leaders and Seed to Supper Instructors Interview Questions

9. Selected Comments from Seed to Supper Participants related to Question $1 \quad 82$

10. Selected Survey Comments about Classes Survey Question 15

11. Selected Seed to Supper Interviewee Comments about Community 87

12. Community Members and Leaders-Group 3 Comments about Value of Community Building

13. Responses from Seed to Supper Instructors on the Effectiveness of Program

14. Comments from Community Member on Place-based Learning

15. Selected Comments from Seed to Supper Participants on Learner Empowerment

16. Comments from Community Members and Leaders about Learner Empowerment

17. Aspects that Influence Purchase of Fruits and Vegetables

18. The Impact of Cost and the Importance of Fresh Fruits and Vegetables

19. Comments about Container Gardening and Comments about Access to Garden Space

20. Selected Comments from Seed to Supper Participants Interviews Related to Transportation

21. The Impact of Limited Transportation Options on Food Insecure Communities 


\section{LIST OF FIGURES}

1. Demographics for Oregon Food Bank Seed to Supper Survey Respondents

2. Example of Survey Questions with Statistical Analysis 72

3. Seed to Supper Survey Question $1 \quad 80$

4. Seed to Supper Survey Question 2

5. Seed to Supper Survey Question $7 \quad 80$

6. Abundant Garden Bed 83

7. Photo of Garden Signage I 98

8. Photo of Garden Signage II 99

9. Survey Comments about Learner Empowerment 100

10. Barriers to Obtaining Fruits and Vegetables or Growing Your Own 106

11. Survey Results for Additional Items Needed to Grow a Garden 107

12. Frequency of Consumption of Fruits and Vegetables 108

13. Multnomah County Ecoroof Community Garden 114

14. City Hall Community Garden $\quad 115$

15. Seed to Supper Participant Shopping Patterns 117

16. Participants Agree They Have Enough Experience to Grow Some Fruits and Vegetables

17. High Percentages of Seed to Supper Participants have Grown Food Within Two Years 


\section{Chapter 1: Introduction}

\section{Learning Garden Scene 1: Brookplace: A Growing Learning Garden Community}

It was the first annual health fair day at Brookplace Housing Complex in the Portland, Oregon area. The late summer sun shone on the bountiful garden beds as people gathered in groups around the information tables hosted by healthcare professionals talking about food, household safety, and other health-related topics. The barbeque filled the air with the smell of turkey burgers as the fair goers stood in line for free fresh blueberry smoothies.

The Brookplace public housing complex is a bustling, vibrant community and their learning garden is often at the center of this community/neighborhood. The members of the Brookplace community are considered food insecure due to lowincome levels and the distances they live from affordable local fresh food. However, Brookplace is different from other housing complexes. Members of this community have initiated a learning garden where gardening classes and potlucks take place. Thirty of the residents grow fresh produce in this garden and build relationships with their neighbors while working together.

Because of its vibrant community garden, Brookplace is an example of a community working toward a sustainable community food system. Sustainable food systems embrace the values of the sustainability movement by honoring the viability of the natural environment for future generations. Sustainable food systems provide more access to resources used to produce, process, distribute and consume food. Additionally, sustainable food systems empower people within 
social, political and economic contexts (Center for Agroecology \& Sustainable Food Systems, 2010). Brookplace shows the potential of learning gardens to promote sustainability, community and empowerment for residents. The Oregon Food Bank's Seed to Supper learning garden program has been a catalyst and resource for sustainable change at the Brookplace gardens for its members through its goals to create community food security, increase self-reliance and improve nutrition through food security. The Seed to Supper program is building sustainable community food systems through learning garden workshops, gardening classes and nutritious use of locally grown foods and thus helps communities and neighborhoods make a difference for its members' food security. The purpose of this study was to discover whether and how learning garden programs such as the Seed to Supper increase participants' access to locally grown food and successfully include and empower food insecure people and their communities.

\section{Historic Patterns that have Influenced Food Insecurity and the Rise of Food Banks and Learning Gardens}

This chapter explains and defines the background and history of food insecurity and the response from food banks to create local solutions to food insecurity. There are many political and economic patterns that have influenced food insecurity in the United States. The history of recent food insecurity provides context for Oregon Food Bank's Seed to Supper learning garden program. This chapter begins with an overview of the political and economic underpinnings of learning gardens within the constructs of globalization and the corporatization of food systems—locally, nationally and globally—as well as the role of food banks and 
learning gardens within this political system. Historic patterns which have influenced food insecurity and the rise of food banks in the latter $20^{\text {th }}$ century provide a perspective for this study.

After examining this historical context, this chapter describes what the local food movement in Portland, Oregon has done to address food insecurity and then specifically introduces Oregon Food Bank's Learning garden program-Seed to Supper. The chapter concludes with a review of the research questions explored in this study.

What is Food Insecurity?

By examining food insecurity we can better understand the context for sustainable community food systems in today's large-scale globalized corporate food systems. This study examines food insecurity in the United States, and how learning gardens impact local food systems in the Portland, Oregon region. Food security and access to locally-grown foods have become increasingly difficult for millions of people in the United States. Food security has been defined as the ability for communities of people to have monetary and physical access to healthy and culturally appropriate foods (Hawken, 2007; Winne, 2008). Food security ensures that all people have consistent access to healthy and culturally appropriate foods (Hawken, 2007). Anderson and Cook (1998) describe food security as: ... access by all people at all times to enough food for an active healthy life and includes at a minimum: a) the ready availability of nutritionally adequate and safe foods, and b) the assured ability to acquire acceptable foods in socially 
acceptable ways (e.g. without resorting to emergency food supplies, scavenging, stealing, and other coping strategies). Food insecurity exists whenever [a] or [b] is limited or uncertain (p. 143).

Food insecurity is a complex issue in today's globalized food system and activist Paul Hawken (2007) advocates for both national food supplies and policies, and for personal self-sufficiency, thus creating balance between subsidized foods and the knowledge and land available to grow food locally and for exports. According to Hawken (2007) food systems have become a complex balance in a growing global economy.

The lack of food security has developed from many decades of economic and agricultural policies that have created a global (large-scale and centralized) food system that has disrupted local and sustainable community food systems. Large-scaled food systems have created barriers for access to locally grown and culturally appropriate foods for many populations (Winne, 2008; Poppendieck, 1998). The agricultural shifts implemented during and following the Green Revolution that took place in the mid $20^{\text {th }}$ century have had an impact on local food systems and contributed to changes in food patterns. During the Green Revolution, the economic and political landscape adapted from supporting smaller-scaled agrarian philosophies and practices to supporting larger-scaled chemical and technological systems. 
Agricultural, Economic, and Political Patterns of the mid-to-late $20^{\text {th }}$ Century

The Green Revolution was an extraordinary moment in the history of modern food systems that changed patterns of agriculture throughout the globe. Initially sponsored by the Rockefeller Foundation (McMichaels, 2008), the "paquete tecnológico or technological package began in Mexico," (Barndt, 2008) and included hybrid seeds, agrochemicals, large-scale water systems and heavy duty farming machinery that introduced a new and modern way to raise crops. This industrialization of agriculture spread throughout the third world to developing countries and became know as the Green Revolution (Barndt, 2008). The Green Revolution promised to eradicate hunger and food insecurity worldwide and insured that U.S. agricultural interests would prosper and feed the world (McMichaels, 2008). This trend developed throughout the 1940s and 1950s and prospered into the 1970s impacting small-scaled agricultural traditions.

During the 1970s, the creation of a large scaled, global and centralized food system developed along side the rise of a free-market economy. As free-market and neoliberal economic policies of the 1970s shifted the government support of federally funded social welfare programs to the private sector, the social safety nets of the 1960s War on Poverty began to disappear (McMichaels, 2008; Poppendieck, 1998). These safety nets included food stamps, welfare, public housing, the Head start program for underprivileged children, affordable higher education and other basic entitlements. This decline of publically supported safety net programs created the need for food banks and programs to help food insecure populations. 
As safety net programs declined, food insecurity was exacerbated by largescale population shifts in cities and rural communities as well as economic decline due to the oil embargo of the 1970s, decreased manufacturing jobs and diminishing natural resources (Winne, 2008). In the United States, these trends translated into fewer lucrative manufacturing jobs and a growing insecurity about the environment and the resources that had been taken for granted by post WWII populations.

Digging into the complexity of the United States' hunger issues, the beginnings of global economic policies supported by the United Nations' New International Economic Order (NIEO) in the 1970s, focused on large-scale corporate world order and less government/nation-state controls (McMichaels, 2008). This UN policy played a role in both the growing food insecurity and the development of industrialized global food systems. As global food systems prospered for transnational corporate interests and profits, the phenomenon of the "paradox of hunger" amid the plenty, impacted many populations throughout the world (McMichaels, 2008; Poppendieck, 1998). In the United States, emergency food programs and hunger relief efforts began to form in the 1970s and 1980s, and food banks began to re-distribute the food surpluses generated from the industrialized and global food systems. The United States, the land of plenty, experienced growing food insecurity in urban settings and lack of access to affordable and healthy foods for increasing numbers of communities (Winne, 2008).

Food deserts began to emerge in urban settings. As middle class populations vacated urban centers for the suburbs in the 1970s, supermarkets, with 
vast selections and affordable products, also vacated to the suburbs, leaving behind fast food convenient stores and restaurants to fill in the gaps (Winne, 2008). The USDA defines a food desert as a "low-income census tract where a substantial number or share of residents has low access to a supermarket or large grocery store" (Ver Ploeg, et al.). Food deserts proliferated on the landscape as the urban to suburban migrations continued through the 1980s.

1980s-2000s: Emphasis on Economic Reform Impacts Food Security The earlier economic and agricultural policies explained above would set the scene for later expansion of corporate driven food systems. Local food systems and social safety net systems declined at the same time and impacted food security. With the momentum for less government spending on social safety nets, the 1980 s firmly established free market ideologies and neoliberal economics that dominated America's food systems (McMichaels, 2008; Poppendieck, 1998; Winne, 2008). The ideology of a trickle-down economy that would take care of the hungry through increased private charity and the power of individual giving was instituted. In the 1980s, food banks were growing in numbers in order to accommodate the increasing number of food insecure communities (Poppendieck, 1998; Winne, 2008). Following the free market reforms of Reagan administration in the 1980s, in the 1990s the Clinton administration instigated welfare reform, with reductions in welfare support and stricter enforcement of food stamp policies.

In the new political climate of the 1990s Clinton administration, where poverty was once managed, "we were ending welfare, not poverty, as we knew it" 
(Winne, 2008, p. xx). Emergency food activists, researchers and social justice advocates Poppendieck (1998), Winne (2008), and Gottlieb \& Joshi (2010) cite this critical policy change as a pivotal point for America's hunger relief agencies. This powerful ideological change has had a direct impact on today's hunger relief policies, which focus on eliminating hunger at its roots and on the proliferation of self-reliance programs including urban learning garden programs.

The Rise of the Counterculture and its Impact on Food Security The rise of America's hunger relief programs along with community learning gardens was also impacted by the counterculture response to industrialized food systems of the latter $20^{\text {th }}$ century. The counterculture response has had an impact on today's food justice and community food systems (Belasco, 2007; Gottlieb \& Joshi, 2010).

The second half of the $20^{\text {th }}$ century was a period of declining access to healthy and locally-produced foods. At the same time, an interest in and revival of "growing your own food" and the "back to nature movement" co-existed and was growing steadily into a full-blown food movement. Belasco (2007) has written a chronicle of the counterculture response to the industrialization of food, documenting that much of the liberal response to the "mainstream food-militaryindustrial complex... was seen as industrialism gone berserk, wrecking the delicate balances of eternity" (p. 25). The new left was disillusioned and observed worldwide symptoms of ecological imbalance (Belasco, 2007). According to Belasco (2007), the early counterculture food movement created a consumerism that 
eventually developed into natural foods branding and the organic food movement. This early rendition of the local food movement from the 1970s has grown and more recently has turned its attention from organic and safe foods to locally-grown foods and to the promotion of food justice and sustainability.

The Food Movement of the 2000s: Food Justice, Learning Gardens and Community Food Systems

As food justice and sustainability agendas influenced the food movement of the 2000s, grassroots groups and local communities took action. Winne (2008) describes the outcomes of these grassroots efforts to create community food systems as a time when farmers markets, community supported agriculture farms, and community gardens were "exploding in numbers" and food democracy was being cultivated by local organizations and food policy councils. There has been an emphasis on economic and social justice (Winne, 2008, p. x). These local food activities, with a history spanning four decades, have fostered and gained strength in the sustainability movements of the $21^{\text {st }}$ century.

The food justice and sustainability movements have been closely aligned with the environmental movement through the use of activism and grassroots efforts (Hawken, 2007; Gottleib \& Joshi, 2010). Both the sustainability and food justice movements focus on social disparities and core issues of equity, empowerment, and social change. Food justice advocates strive to build healthier food systems (Gottleib \& Joshi, 2010). Central to food justice is a clear definition of "food system." Gottleib \& Joshi (2010) write: "a food system is best 
described as the entire set of activities and relationships that make up various food pathways from seed to table and how these might influence our foods and communities" (p. 5). With these food pathways clearly defined, many food justice groups mobilized to create local solutions to help alleviate food insecurity (Winne, 2008).

One solution brought about by the influence of environmental activism and the sustainability movement contributed to a national obsession with community gardening (Lawson, 2005). Food banks began to use learning gardens as an educational tool to promote self-reliance and improve access to fresh locally grown foods.

Just as the counterculture advocated for growing one's own food in the 1970s, food justice advocates have focused on community learning garden programs in the 2000s as a remedy for food insecurity and as a way to build local networks for sustainable food systems. The development of sustainable local food systems has been used to create strategies to address many of the inequities affecting our society and environment due to an unsustainable and unjust food system (Gottbieb \& Joshi, 2010). The learning garden is included as one of the strategies to address food insecurity and to create spaces that empower individuals within the context of self-reliance. In response to a dramatic and environmentally damaging industrial food system, the rise of food banks, and programs like the Oregon Food Bank's Seed to Supper learning 
garden program, have contributed to a surge of activity and concern over the United States' increasing food insecure populations.

\section{Rise of Food Banks and Learning Gardens}

With the growing numbers of food insecure populations, food banks were forced to create larger emergency food distribution centers and to develop social services to accommodate the lack of social safety nets (Gottlieb \& Joshi, 2010; Poppendieck, 1998; Winne, 2008). Recent statistics from the USDA, (2012) reveal in record numbers that approximately 44.7 million Americans are receiving food stamps, renamed the Supplemental Nutrition Assistance Program (SNAP) in the 2008 Farm Bill. While the combined forces of economic decline, global warming, diminishing supplies of natural resources, and exploding human populations impact our planet, the local food banks and food justice activists have made efforts to assist underserved urban areas with programs such as learning gardens, farmer's markets and Community Supported Agriculture (Gottlieb \& Joshi, 2010; Winne, 2008).

As food security in the United States has become unstable, food banks have stepped in to help alleviate hunger and food insecurity through emergency food systems. Fisher (2005), in his opening comments to the Community Food Security Coalition postulated that no group has taken on the role of alleviating food insecurity better than the network of food banks throughout the U.S. These groups have tried to shape the economic and political policies that often cause hunger including poverty, joblessness, lack of health care and education. Fisher states: 
...increasingly, groups such as food banks, shelters, and churches, while continuing to feed people in hunger and house the homeless, are sponsoring food security related programs that included food sector job training, nutrition education, healthier food choices, community gardens, links to local farms, and economic development (2005, p. 4).

Why have food banks taken on these multiple roles? And how can a learning garden improve food security? The answers to these questions unfold as we examine what the learning garden can teach us. The learning garden has captured the collective imagination of United States (Gottlieb \& Joshi, 2010). The recent garden installation at the White House illustrates the renewed emphasis on growing our own food. As briefly described, the role of food banks has a forty-year history stemming from the economic and political activities from the 1940s through the 2000s that have influenced our food systems. Within this context, learning gardens have become places for creating food access, empowerment, food literacy and sustainability.

\section{Why Study Learning Gardens?}

Learning gardens have been loosely defined over the decades and often have been referred to as victory gardens, community gardens or urban learning gardens. Many learning gardens have been affiliated with children and schools and for at-risk students and adults (Lawson, 2005). For the purpose of this study, the working definition for Garden-Based Learning (GBL), as described by Desmond, Grieshop and Subramaniam (2002) best defines a learning garden as: ... "simply an instructional strategy that utilizes a garden as a teaching tool. The pedagogy is 
based on experiential education, which is applied in the living laboratory of the garden" (p. 9).

While learning gardens have proliferated throughout history during economic hard times, and are often seen as a "panacea" for building self reliance and empowerment, there is also the fear that "they can become a tool for paternalistic goals or [that] the goals become too broad to be achievable"(Lawson, 2005, p. 293). Much of what we attribute to learning gardens and the altruistic themes that embody them have not been thoroughly researched over the past few centuries and anecdotal evidence is largely what academics, urban planners and educators have used to base much of the discussion about learning gardens (Lawson, 2005). Lawson (2005) writes, "the downside is the high ideals associated with gardening rarely can be documented or verified. The tendency to layer multiple agendas on gardens makes achievable objectives difficult to ascertain..." (p. 11). This lack of evidence-based research motivated this research focusing on the learning garden in the social context of food security and access to locally grown foods as well as notion that these programs can build self-reliance through learning gardens.

The next section addresses the local food movement in Portland, Oregon and its focus on increased access to locally grown foods, and the importance of sustainability in the local food movement. This study analyzes the Oregon Food Bank's Seed to Supper Program within the context of equitable and fair distribution of power. Specifically, this study looked at how the Seed to Supper program impacts access to locally grown food. 


\section{The Local Food Movement in the Portland Area: Background for Study}

In 2009, a preliminary study sponsored by the McNair Scholar Program, allowed for an analysis of one segment of Portland, Oregon's burgeoning local food movement-learning gardens that focused on food insecure families and access to locally grown foods. Several learning garden programs initiated programs and spaces for food insecure people to learn about growing their own food. The Oregon Food Bank (OFB) and its Learning Garden Program--Seed to Supper agreed to work with me as a researcher and garden educator to help them analyze the effectiveness of their program.

Portland, Oregon is considered one of the leading sustainable and "green" cities in the United States, and supports a growing urban agriculture community. There are dozens of community gardens and learning gardens located in neighborhoods throughout the city and surrounding communities. Community supported agriculture (CSA), farmer's markets and food co-ops have prospered and grown in membership and participation over the past decades and Portland ranks high in sustainability areas such as land use planning, recycling, green buildings and green economies.

Sustainability has become a focal point in Portland with a movement toward local, earth-friendly food and public health policies to support these trends. There is a growing movement to integrate these trends and create a more unified approach to food policy and social justice with sustainability and public health in mind. Portland formed its own Food Policy Council in 2004 confirming its role as a 
progressive city dedicated to creating a sustainable model. However, the lack of a national food policy has been identified as a major issue for the $21^{\text {st }}$ century by authors and activists Michael Pollan (2008), Francis Moore \& Anna Lappé (2002), and Mark Winne (2008). In absence of national policies, cities like Portland help to lead the way and set the standard for a national food policy.

Several Portland community leaders have identified the need to integrate cultural and economic diversity when addressing food security issues in the Portland region (Withers, 2010). They point to areas of Portland where there are few options to low-income families in terms of obtaining healthy fresh foods. In addition to the economic disparity that plagues many families in our community, commercial agribusiness and its retail culture offer few nutritious foods to lowincome families. Many street intersections in business and neighborhood sections throughout the city offer only fast-food restaurants or convenience stores on each corner. Research and investigative reporting by authors like Eric Schlosser (2001) and documentaries such as Super Size Me by Morgan Spurlock (2004) have shown that the food sold in these establishments is highly processed and lacks nutritional quality. Many neighborhoods in Portland offer little more than fast and convenience foods creating "fresh-food deserts" for inhabitants. It is in this landscape and political setting that the Oregon Food Bank works to counter food insecurity. Community learning gardens are one alternative to the prevailing fast food culture. Additionally, diverse populations often embrace gardening and bring their knowledge to learning garden programs and the community (Withers, 2010). 


\section{Oregon Food Bank's Seed to Supper Program}

The Oregon Food Bank (OFB), initially called Oregon Food Share, was founded in 1982 when revenue losses from decreased food and timber industries had statewide impact on hunger statistics. The mission statement of OFB has focused on "eliminating hunger and its root causes...because no one should be hungry" (OFB, n.d.). Now a hub for over 900 hunger-relief agencies, in 2010/2011 the Food Bank distributed over one million food boxes throughout the state. In addition to delivery of 91 million pounds of food donations, the OFB has developed an effective public policy advocacy program, nutrition and learning gardens program, and several community partnerships advocating for community food systems including FEAST (Food, Education, Agriculture Solutions Together), RARE (Resource Assistance for Rural Environments) and Food for Oregon.

This proactive approach effectively results in substantial poundage of food donations generated locally, statewide and through donations from national food programs like Feeding America, formally known as Second Harvest. Feeding America is the nation's food bank network and a major clearing house of Food Industry giants like ConAgra, Kroeger, WalMart, Nestle, and Cargill. Oregon Food Bank is a premier example of a food bank that delivers food to the needy. As Executive Director of Feeding America Bill Ayres notes in Building The Bridge: Linking Food Banks and Community Food Security, "Food bankers know that for hunger to end, people must be empowered to achieve self-reliance" (Fisher, 2005). Additionally, he writes that: 
Food bankers have always seen themselves as a part of the community as a whole...as the Community Food Security movement has grown, food bankers have joined its efforts to ensure that every community has access to safe, nutritious, affordable food... many food banks today have their gardens, farms, farm stands and partner with Community Supported Agriculture, resulting in more fresh food for hungry people (Fisher, 2005, p. 3). Oregon Food Bank, noted in the field for its achievements as a food bank, both in terms of the amount and quality of food given as well as its creative advocacy programming, is featured as an example in Winne's (2008) Closing the Food Gap: Resetting the Table in the Land of Plenty and in Fisher's (2005) status report on the comprehensive work of U.S. food banks and their linkage to Community Food Security. The fact that America's food banks have become clearing-houses for social services to aid America's food insecure and at the same time promote programs that build self-reliance is a key factor that influenced the development of this study of the Seed to Supper learning garden program.

The Seed to Supper learning garden program was founded in 2004 as one of OFB's initiatives for building food security through improved nutrition, community food security and self-reliance. Other OFB learning garden programs include: Cultivating Community, for at-risk youth, and Dig In, a community gardening program for members at large to grow and donate fresh organic produce to the food bank. The Seed to Supper program partners with local and state social service 
agencies to host and teach basic gardening classes. The demographic for the Seed to Supper participants correlates with the general demographic data for those receiving a monthly emergency food box (Oregon Food Bank, 2080). Agencies affiliated with housing authorities, community centers, Head Start and other hunger-relief agencies host gardening classes, workshops and information fairs to aid participants in growing fresh produce, preparing nutritious foods and learning new life skills.

This study grew from a preliminary study conducted in 2009, which indicated that low-income participants in the Seed to Supper Program did not shop at the farmers markets or use Community Supported Agriculture (other than OFB programs). However, the results of the 2009 study have shown the social impacts of community building, nutrition, education and increased self-sufficiency on participants can improve access to locally grown foods (Withers, 2010). Additionally, Seed to Supper participants readily offered suggestions and recommendations for program improvement.

\section{Research Questions and Importance of Study}

This study looks at food equity and access within the context of urban agriculture and place-based learning in the Seed to Supper program. The basic research questions are: 1) How does the Seed to Supper Program impact food insecure communities and their access to fresh grown and local foods? 2) How are the goals of the Seed to Supper framed/designed and presented in the served communities? 3) Do these goals accomplish the overarching need for increased 
food security in urban and peri-urban Portland? 4) Does the Seed to Supper

Program improve food literacy, self-reliance and create social capital?

\section{Community-based Research}

This study is an example of how collaboration between the academy and the community can bring about change by working with participants and their ideas for improving their learning gardens. My goal is to bring the voices of these gardeners and the results of their efforts to public policymakers that promote Community Food Security. Heffner, Zandee, and Schwander (2003) assert that "Communitybased research can be a bridge between the academy and the community, providing a forum for building relationships, learning from one another and working together for social change" (p. 127).

In this case, the community partner - OFB/Seed to Supper-was seeking information on the results of the program and solutions to improve the program. Many of the initial results and recommendations have already been presented to Oregon Food Bank and other community partners and have led to changes and additional partnerships to the program and participating communities.

\section{Overview of Chapters}

The following chapters include a literature review that examines the history of learning gardens, garden-based pedagogy, and an overview of food insecurity concepts within the framework of community food security and food democracy. Chapter three focuses on this study's research methodologies, including information on how the study was conduced and who participated. Additionally, I include my 
personal background experience as a researcher and the impact this research had on the sites where I conducted this study.

Chapter four describes the results of the study. The final chapter includes a discussion of the discoveries and the relevance this paper could have on programmatic changes, public policy and food justice. This discussion describes the implications for empowering food insecure populations through active citizenship and pathways to food democracy and food justice. Finally, Chapter 5 includes a discussion on how community-based research and the participation of the academy can impact local change and policy and engage community food systems.

At the beginning of each chapter in this thesis, a brief description from one of the learning gardens scenes opens the chapter. These thematic scenarios introduce the content of the chapters and the characteristics from that learning garden community. All the site names are pseudonyms. The following chapter focuses on the literature related to this study's focus on learning garden programs. 


\section{Chapter 2: Literature Review}

\section{Learning Garden Scene 2: Forest Hills: a Historic Community Garden}

The recently restored learning garden at Forest Hills public housing project, originally designed and built in the mid-1940s, is also Oregon's first public housing project. As World War II ended, victory gardens still had a place in small communities to ensure food security for its members. The Forest Hills community garden was designed for a half-acre plot at the center of the housing project. Over time the garden fell out of use and was abandoned by the 1980s. In 2009, a services coordinator for Forest Hills Housing Complex, with the support of the community, decided to restore the garden to its original site. Today, the Forest Hills community garden is coming back to life through on-site garden programs, including Oregon Food Bank's Seed to Supper gardening classes, healthy cooking classes, a children's garden, a community composting system and a plant identification system for the garden created in partnership with a Portland State University capstone course. The community garden is open to members of Forest Hills public housing project and access to locally-grown foods increases with their participation in the learning garden program. This historic community learning garden site sets the scene for this chapter's focus on the literature, which captures how learning garden programs impact food insecure populations.

\section{Overview to Literature Review}

This literature review discusses research and theories showing the relationship between community food security, sustainability education as well as 
how these concepts impact local, sustainable community food systems. After providing a brief history of learning gardens and sustainability goals, this chapter examines educational theories of the past century and how they have influenced garden-based education and place-based learning. Then, through the lens of garden-based education, this chapter explores food literacy and its connection to food security. Next, this literature review examines the importance of ecoliteracy (ecological literacy) and the sustainability movement in education to garden-based learning because learning gardens have become vital places to convey the goals of both ecoliteracy and sustainability movements (Gaylie, 2009). Following the discussion about sustainability education, this review seeks to explore the relationship between community food security, food democracy and food justice.

According to community food security advocates, food democracy and food justice are evident in communities with improved food security (Gottleib \& Joshi, 2010; Winne, Hugh and Fisher, 1997; Winne 2008). Furthermore, as the literature indicates, there is an assumption that garden-based learning may empower and help facilitate food equity and access (Gottlieb \& Joshi, 2010; Nordahl, 2009; Winne, 2008).

Food advocacy groups such as the Community Food Security Coalition (CFSC) movement have identified food inequities economic and social in our infrastructures that impede access and create daunting barriers to culturally appropriate foods for many low-income populations. For the purpose of this study "low-income" 
populations are henceforth described as "food insecure"(Poppendieck, 1998, Winne, 2008).

\section{Historical framework for Learning Gardens: What is a Learning Larden?}

As the Forest Hills learning garden has shown learning gardens have the potential to help food insecure populations access local foods. This study begins with a description of the history of learning gardens and of the impact this history has had on today's learning garden programs. The history of learning gardens reveals patterns and trends that portray the garden as a tool to empower people and improve their access to fresh locally-grown and culturally appropriate foods (Lawson, 2005; Winne, 2008)). The Seed to Supper program is similarly modeled after learning garden programs designed in the early 1900s and the goals are also similar - to empower and build self-reliance, to beautify, and to improve access to locally-grown foods thereby alleviating food insecurity. Anecdotal portrayals of the garden as a paradise, where humans can co-exist with nature in harmony without much resistance, dominate much of the literature about gardens (HondagneuSotelo, 2010). The garden as a paradise is a cultural assumption found throughout the literature. If gardens serve as a place to teach self-reliance, increase access to foods and empower people, then a brief overview of the history may determine whether there is a connection between learning gardens and food security.

The definition of learning gardens can be traced over 100 years--dating back to the 1890s when urban and community garden development in United States expanded. Learning gardens have served many social, economic and educational 
purposes. Laura Lawson (2005) has described some of these historic meanings of learning gardens over time, and postulates through her extensive research of garden programs in America that many of the assertions and claims about the benefits of learning gardens "were largely anecdotal" (xv). She also found the presence of learning garden "projects" practicing similar "patterns in organizational development, with typical justifications and goals for these projects" (xv). Public support for these projects has proven to be cyclical with stronger financial support during economic hard times, and often little support once "public attention shifted" (Lawson, 2005, p. xv).

Lawson's (2005) historical analysis in the book, City Bountiful: A century of community gardening in America has found that "in times of crisis, the neighborhood garden becomes a place to go, to get active, to meet neighbors and to make life more palatable" (p. 292). As early as the 1890s, vacant lots were developed into community gardens to assist unemployed laborers in Detroit, New York, and Philadelphia (p. 1). In addition to this social/economic reform activity, education reformers focused on developing urban gardens in vacant lots and in schoolyards in order to promote "interactive teaching venues that correlated with school subjects and taught civics and good work habits" (p. 1). As early as the 1890s, school gardens became a national movement, and by 1914 the U.S. government formed a special office in the federal Bureau of Education dedicated to school gardens called the Division of Home and School Gardening (Lawson, 2005). 
Considering this historical perspective, much contemporary thinking about learning gardens and garden-based learning seems to derive from previous philosophies related to gardening and education. UN researcher, Subramainam, (2002) states: "The philosophy behind garden-based education is actually an amalgamation of the philosophies behind experiential education, ecological literacy and environmental awareness, and agricultural literacy" (p. 1). The history of learning gardens emphasizes the capacity of urban gardens to remedy our social ills, provide beautification, bring nature to our cities, and act as a place to further our knowledge base (Lawson, 2005). Lawson (2005) writes that urban garden programs were designed to improve urban conditions. At a time of great social and economic change in the United States of America, urban gardens improved housing situations and provided tangible outcomes that appealed to the general public. The success of these types of garden programs was repeated over time and today's successful learning garden programs grow out of this history and purpose.

\section{The Goals of Sustainability Education}

In addition to the history of learning gardens, the goals of sustainability frame learning gardens as a tool for sustainability education. Gaylie (2009) asserts that learning gardens play a transformative role in addressing sustainability education goals and aid in providing common spaces for community engagement. This view is consistent with recent sustainability goals set by international organizations such as the United Nations Educational, Scientific and Cultural Organization (UNESCO). These sustainability goals were formulated to address the 
mounting environmental concerns of the $20^{\text {th }}$ and $21^{\text {st }}$ centuries. UNESCO has set the objectives for the UN decade of sustainable education (2005 - 2014) which "seeks to integrate the principles, values and practices of sustainable development into all aspects of education and learning, in order to address the social, economic, cultural and environmental issues we face in the 21st century" (UNESCO, 2012).

Sustainability education "aims to help people to develop the attitudes, skills, perspectives and knowledge to make informed decisions and act upon them for the benefit of themselves and others, now and in the future" (UNESCO, 2012, p. 2). Although prescriptive in nature, these goals have shaped and impacted the development of garden-based learning for furthering sustainability goals through the living laboratory of a learning garden. If the learning garden can help alleviate food insecurity and address some of the barriers to accessing locally grown foods, this outcome will contribute to the furtherance of sustainability goals.

This study posits that the learning garden is well positioned to serve as an educational tool to expand community solutions for sustainable social ecosystems to support local, sustainable food systems. The next section looks at specific learning garden pedagogy and its importance to learning garden programs.

\section{Learning Garden Pedagogy}

Because of the nature of the learning garden as a hands-on experiential learning process, programs like the Seed to Supper have adopted teaching methods that draw on experiential learning pedagogy. The learning garden provides an alternative to the classroom as well as access to an outdoor learning environment 
(Subramaniam, 2002). In framing this research study, an examination of the various approaches by garden educators reveal that many pedagogical concepts have remained consistent. Subramaniam, 2002 states, "Today, the ideas of experiential and naturalistic education, integrated curriculum, and the ideals of environmental education and agricultural literacy have found a new context for instruction beyond the four walls of the classroom-the school garden" (p. 1).

The learning theories affiliated with learning gardens are consistent with patterns of educational theories developed over the past one hundred years, along with the addition of environmental and sustainability goals in the $20^{\text {th }}$ century. Additionally, the influence of $19^{\text {th }}$ century educational theorists on place-based and experiential learning has been associated with progressive educational theorists, such Kolb, Dewey and Gandhi. Another consistency is the overall lure of the garden as a panacea for society's ills, which Lawson (2005) maintains has compromised the creditability of urban gardening, and may be one reason for the lack of permanency on the landscape from the 1890s through the 1990s. In spite of its lack of permanence, the learning garden has captured the interest of educators over the past two centuries.

Experiential Learning Theory and the Garden.

Learning garden pedagogy has been influenced by the educational theories of experiential learning, a Western European framework for learning derived from the progressive educational theorists John Dewey, Maria Montessori, Mahatma Gandhi, and more recently Kolb (Desmond, Grieshop, \& Subramaniam, 2002; Gaylie 2009; 
Subramaniam, 2002). Experiential learning and education have been defined as "a process through which a learner constructs knowledge, skill, and value from direct experiences" (Subramaniam, 2002). Gaylie (2009) has identified the roots of experiential learning in early philosophical writings of Jean-Jacques Rousseau, Johann Heinrich Pestalozzi, and Friedrich Froelbel. These early philosophers saw the critical importance of learning in nature through observation and being out-ofdoors - the premise for experiential learning. Pestalozzi coined the phrase, "hands, heart and head" (Subramaniam, 2002; Gaylie, 2009) to describe the emphasis in hands-on learning. Pestalozzi was an early supporter of schoolyard gardens in the $19^{\text {th }}$ century (Subramaniam, 2002) a time when there was a proliferation of learning gardens in public schools. These early theorists continue to influence today's garden-based learning objectives as do the theories of modern educator John Dewey, a major influence on experiential learning.

John Dewey, a $20^{\text {th }}$ century American theorist of the progressive education movement, saw the naturalist environment as a realistic and powerful opportunity to teach about the sciences. He asserted that the history of humans and their relationships to the working environment might promote the humanitarian causes of the $20^{\text {th }}$ century. He states that "education in order to accomplish its ends for both the individual learner and for society must be based upon experience-which is always the life-experience of some individual" (Dewey, 1938, p. 89). Dewey's contribution to $19^{\text {th }}$ century experiential learning theories is the $20^{\text {th }}$ century ideology (politics) associated with progressive education. Another politically 
motivated educator, Mohandas Gandhi, believed in moving education from "the confines of the fours walls of a classroom" (p. 1) in order to bring practical applications to learners (Subramaniam, 2002). Experiential learning defined outdoor education models and nature-based learning that blossomed after this mid$20^{\text {th }}$ century thinking. Gandhi's model of "self-sufficiency," which advocates developing independent communities, is an important influence on our current educational framework for learning gardens and their goal of helping others to develop self-sufficiency. In the $21^{\text {st }}$ century, garden educators and philosophers are still theorizing about experiential learning practices as they relate to gardeners.

Another experiential learning theorist, Kolb, adapted his experiential learning model from Dewey, Piaget and Lewin creating a "holistic model of the learning process and multilinear model of adult development, ...which is consistent with what we know about how people learn, grow, and develop" (Kolb \& Boyatzis, Mainemelis, 1999, p. 2). This model for learning starts with a concrete experience based on doing followed by an activity reflecting on the experience. Following this reflection activity, the learner concludes the experiences through a conceptualizing activity, and lastly, an active experiment, planning or trying what was learned (Kolb, 1984). The learning garden provides the perfect canvas, so to speak, for this model of experiential learning.

Gaylie (2009) suggests that: "the garden itself is a paradox in that it represents a simple, local solution to large, complex, global environment problems. Learning in the garden is immersion in dichotomy and difference as a bridge towards 
understanding and community"(p. 8). This paradox is evident in many of the complex problems educators, planners, and community organizers face in the $21^{\text {st }}$ century. Certainly Dewey and Gandhi, among others, argued for the use of gardenbased learning in a place-based context as well as for the potential for powerful learning experiences and community building.

Place-based Learning in the Garden.

These theorists and educators saw value in real life learning, recognizing the significance of place-based learning. This study has sought to identify what role place-based learning has in the success of learning garden programs. More recently, place-based learning advocates have focused on the contribution learning gardens can make to creating sense of place and empowering people. According to Lawson (2005), and Hondagneu-Sotelo (2010), the garden has been promoted as a place that creates a sense of well-being, and promotes self-reliance. One of the foundations of place-based learning is the use of an integrated and versatile curriculum—one that is related to place and to community. Because of this versatility, Gruenewald (2003) describes the unique aspects of place-based learning as a theory that:

...lacks a specific theoretical tradition,... its practices and purposes can be connected to experiential learning, contextual learning, problem-based learning, constructivism, outdoor education, indigenous education, environmental and ecological education, bioregional education, democratic education, multicultural education, community-based education, critical 
pedagogy itself, as well as other approaches that are concerned with context and the value of learning from and nurturing specific places, communities and regions (p. 3).

Because of this versatility, place-based learning lends itself to a broad range of applications and to a diversity of places and situations. Gruenewald (2003) cites Williams, 2001 as stressing the importance of people in place and the relationship to power and politics as central to place-based learning. The empowerment of the individual that Williams refers to and the relationship to learning in place and building this connection to community, helps define garden-based learning and its popularity. Gruenewald (2003) notes, "place-based pedagogies are needed so that the education of citizens might have some direct bearing on the well-being of the social ecological place people actually inhabit" (p. 4). The potential impact of such place-based learning pedagogies can be applied in garden-based learning. Often learning gardens are located in a community and become a powerful tool for garden educators, community organizers and policymakers. These are a few reasons we need to understand experiential pedagogy within place-based learning theory because these theories can transform and empower people.

The next section of this literature review examines the role of food literacy in current garden-based learning and specifically, in learning garden programs like Seed to Supper. By teaching food literacy, educators can provide a link to food security and to sustainability education. 
Food Literacy in Garden-based Learning: A Link to Food Security

Food literacy is one of the basic precepts used in learning garden programs. Hawkins (2007) defines food literacy as to the degree to which people are able to obtain, process, and understand basic information about food in order to make appropriate health decisions, (p. 238). Learning gardens can increase food literacy and create sustainable lifestyles for food insecure populations and, as Nordahl, (2009) has stated, food literacy may play an important role in building capacity for this knowledge. In her book, The Learning Garden: Ecology, Teaching and Transformation, Gaylie, (2009) asks garden educators “How does a garden teach?” (p. 1). She envisions the garden as a living space for interdisciplinary and ecologybased collaboration, adding that firsthand knowledge of how things grow empowers teachers and students (Gaylie, 2009). Teaching food literacy in learning garden programs has the potential to make a significant difference for food insecure populations. As Gaylie (2009) asserts, firsthand knowledge of how food is grown empowers people and meets the goals of sustainability.

Many educators, urban farmers, and food activists have posited the use of urban learning gardens as one of the building blocks for the local food movement. They also see urban learning gardens as one potential solution for alleviating food insecurity and for building community equity in underserved communities. A growing number of educators and policy makers teaching about how food is grown and the traditions that have perpetuated growing our own food purport these traditions as critical to food literacy (Williams \& Brown, 2012; LaDuke, 2005; 
Nordahl, 2009; Winne, 2008). Learning garden programs stress the cultural importance of linking the processes of growing food and food preparation, creating opportunities for resiliency and developing self-reliance.

Food literacy, a concept adapted by the U.S. Department of Agriculture's health literacy initiative, promotes community health objectives including food and nutrition. According to the 2010 USDA health literacy initiative, the inability to prepare basic foods by food insecure populations has been identified by government researchers as a critical breakdown in our health systems. The link between literacy (knowledge) and our food is major focus for today's health communities. From a seed, as the name Seed to Supper implies, we can create a meal-our supper. This simple concept is used by researchers to describe the link between community health and the importance of culturally appropriate food, nutrition and physical activity (Kolasa, Peery, Harris, \& Shovelin, 2001).

In Nordahl's (2009) book, Public Produce: The new urban agriculture, he stresses the importance of food literacy and the potential of learning about our food from our environment. Additionally, Nordahl (2009) has identified food literacy and knowledge about where our food comes from as important components of a sustainable, local, community food systems. He asserts that "much of this forgotten knowledge surrounding food has much to do about supermarket convenience and the amount of processed and fast foods in our diets" (Nordahl, p. 116). He has identified the social need to learn from our peers within our environment and states, "what we learn is what we see" (Nordahl, p. 116). The knowledge and the 
intergenerational traditions learned from our families and the culture we live in define who we are culturally (Nordahl, 2009). Observing and learning how to grow food in a garden is an important way to learn and develop a culture of food literacy. Based on Nordahl's perspective, I conclude that food literacy is a key component to attaining sustainable community food systems and to overcoming barriers to locally grown food.

This traditional approach of passing knowledge on from generation to generation is fostered in learning communities where place-based experiential pedagogy empowers individuals (LaDuke, 2005; Nelson, 2008; Nordahl, 2009). As Nordahl, (2009) has stated, this culturally intrinsic community-based approach to gaining food literacy in the context of place has important implications for learning garden programs. If research can demonstrate that learning gardens really do impact food insecure populations and improve access to locally grown foods, this knowledge could potentially alleviate the funding problem identified by Lawson (2005). Thinking along these lines—positioning food literacy within the scope of sustainability education, the concept of ecoliteracy defines the connection between ecology, sustainability and educational theories such as experiential and placed based education. Sustainability education encompasses many threads of experiential pedagogy; ecoliteracy has defined sustainability within the concepts of biodiversity and the web of life. The learning garden is the perfect metaphor for teaching sustainability within the experiential learning model. 
Ecoliteracy: Concepts of Sustainability in the Garden

The Seed to Supper program addresses sustainability in subtle and indirect ways through its focus on organic gardening and other stewardship principles. In many of the programs, sustainability has become a focal point. The concept of sustainability is central to garden/place-based learning and fosters a sense of concern and investment in our environment and future generations. Capra (1996) states that "there are solutions to the major problems of our time, some of them even simple" (p. 4). He defines sustainability as a key concept in the ecology movement—and posits this challenge for our time, " to create sustainable communities ...social and cultural environments in which we can satisfy our own needs and aspirations without diminishing the chances of future generations" (p. 4). In addition to Capra's challenge, Costanza (2010) considers urban ecology a focal point of the sustainability movement in $21^{\text {st }}$ century. He stresses the importance of this moment in the Earth's history and the challenges we face in creating a sustainable future. He advocates for the a solutions-based approach. If we are to address the complex socio-ecological systems of our planet, sustainability education is critical (Costanza, 2010). The growing sense of urgency for change in our communities (what Capra calls deep ecology or a paradigm shift) has enabled principles of sustainability to permeate multiple disciplines of learning.

The learning garden lends itself to experiential and sustainability learning in our natural environments and fosters appreciation for stewardship of nature (Gaylie, 2009). The learning garden model offers a "solutions-based" approach to 
teaching sustainable education goals. As Capra (1996) suggests, "from the systemic point of view, the only viable solutions are those that are sustainable" (p. 4). The garden provides a solutions-based approach to sustainability education and provides sustenance for living. Humans are interconnected with nature's web of life and co-exist with nature in the garden (Capra, 2002).

Human interactions in learning gardens can help us understand this web of life theory that is so critical to sustainability education. Capra (2002) stresses the importance of "ecoliteracy" goals for all individuals and has developed the Center for Ecoliteracy in Berkeley, California. Capra states, "ecoliteracy—the understanding of the principles of organization that ecosystems have evolved to sustain the web of life-is the first step on the road to sustainability" (2002, p. 232 233). The Center for Ecoliteracy uses an education system that is based on ecological literacy. This pedagogy is based on the concept that life is part of a complex web and the learning model focuses on "the experience of learning in the real world" (p. 232). In positioning his theory, Capra uses the example of growing food and how sense of place develops from growing our own food, establishing the interconnectedness of all life's cycles, from waste matter into compost, compost into plants and the plants sustain humans. This food system is an ongoing cycle. Ecoliteracy and sustainability education follow the four main principles of the sustainability movement, which include: ecology, economy, equity and more recently education (Edwards, 2005). These goals are imperative to the learning garden and fit the ethics and objectives of sustainability education. The last section 
of this literature review seeks to describe the political/activist aspects of learning garden programs and the connection to increased citizenship and the democratization of food security.

\section{Community Food Security and Food Democracy \& Food Justice}

Proponents of community food security assert that local, sustainable, community food systems are achievable by creating social equity (Fisher, 2002; Winne, 2008). The following section is an overview of the literature that connects community food security, food democracy and food justice. The learning garden as a potential space for learner empowerment sets the scene for greater community food security through activism in food democracy and participation in food justice.

Fisher (2010) has defined food democracy as a concept "based on the principle that citizens or "food citizens" have the power to determine food policies and practices locally, regionally, nationally and globally. Food democracy asserts that it is a right and responsibility of citizens to participate in decisions concerning their food system" (Fisher, 2010). Food Justice, similarly asserts the role of citizenship and empowerment. These two concepts, food democracy and food justice look to rights-based democratic processes to influence control of local, national and global food systems. Food justice came out of the environmental justice movement in the early 2000s (Gottleib \& Joshi, 2010), and is a social justice approach to solving food insecurity issues and to achieving access to locally grown foods. 
The Community Food Security Coalition based in Portland, Oregon and Washington, DC has described community food security as "building local capacity for food production and marketing, distributional equity, social justice, and ecological sustainability"(Fisher, 2010, para 1). As part of its mission to mobilize a rights-based food system, the coalition has created guidelines, measurement tools and a nationwide coalition to help communities create sustainable, healthy, just and local community food systems. They advocate for democratic systems dedicated to building community voice and building capacity for change. Community food security advocates value community participation in decision-making, design and implementation of local food systems. Community food security also applies a community-focus to problems rather than 'blaming the victim' (Anderson and Cook, 1998, p. 145).

The philosophy reflects a rights-based and democratic model that uses social justice principles (Anderson and Cook, 1998). Anderson (2008) further stresses the importance of a rights-based food system, and argues that the U.S. failure to recognize "economic, social and cultural rights (ESCR) as basic human rights on a par with civil and political rights... perpetuates food insecurity, poor health associated with diet and lack of democratic participation in political decisions about food" (p. 595). Food security advocates and researchers have addressed community food security (CFS) and its relationship to community learning gardens as a space for food justice, equity and building resiliency (Winne, Hugh, \& Fisher, 1997). Winne et al. (1997) state "the goal of Community Food Security is to develop 
communities that are food secure" (p. 4). Along with problem solving for food insecure communities, CFS has focused on decentralized and small-scale food systems that promote local access and solutions for lack of access to food.

The concept of sustainable community development that goes beyond 'blaming the victim' has some of its roots in Nobel Prize recipient Amartya Sen's (1999) book Development As Freedom. Sen (1999) has written about the Irish potato famine and the political implications of cultural superiority and cultural alienation (p. 175) found in colonial and post-colonial governments. Sen focuses on the tensions between entitlements (basic economic freedoms) and interdependence and writes that "hunger relates not only to food production and agricultural expansion, but also to the functioning of the entire economy and-even more broadly - the operation of the political and social arrangements that can, directly or indirectly, influence people's ability to acquire food and to achieve health and nourishment" (p. 162).

The political, social and economic factors cited by Sen shed light on much of the current thinking about charity as a reaction to economic disparity. Food banks have picked up the tab so to speak, the Seed to Supper program is one example. There is a danger that charity organizations that promote the concept of the learning garden as a space to learn self-reliance and self-sufficiency may in fact perpetuate a large, abusive system that overshadows societal ills such as poverty (Poppendieck, 1998). Sen's (1999) theories about the right to food as a basic human right underlie the resistance to emergency food as charity. Proponents of 
community food security have criticized the role of charity and instead focused on a rights-based food system (Anderson, 2008).

It is within this context that this study seeks to understand the benefits of the learning garden as a potential democratic space with the power to influence political decisions about food. When considering a rights-based food system with the capacity to empower food insecure communities, the question to ask becomes, how does one measure the success of a community food system? The Coalition for Community Food Security (CFSC) has documented many indicators of successful community food systems as well as a theoretical framework for how to develop these systems. This framework is too in its large a scale for the scope of this study; however, these indicators would be helpful to consider when analyzing the results from this study.

The CFSC's 2010 executive summary, they identified indicators of success based on six years of data collection on their community food program activities and outcomes including: "healthy people, strong communities, thriving local economies, vibrant farms and gardens, sustainable ecosystems and justice and fairness" (p. 1). These indicators of success can be used as tools to analyze learning gardens and their role in community food systems. The goals of the Community Food Security Coalition and the goals of the Seed to Supper program are both intended to alleviate food insecurity and build self-reliance through hands-on experiences.

This study examines a learning garden program that claims to bring gardening skills to food insecure populations with the goal of creating community 
food security. And as Lawson (2005) has asserted, through gardening, one learns not only practical skills associated with gardening-the steps necessary to nurture seed to fruit-but also the civic-mindedness to nurture community open space (Lawson, 2005, p. 7). Lawson (2005) has also maintained that "gardens [serve] as a democratic space and gardening as an activity... brings diverse groups together in mutual self-interest" (p.8). Lawson has identified this as "self-help." Lawson's observation regarding "self-help" plays out through the democratic processes developed in the community food security movement. Food justice practices and rights-based practices can further be defined as activism—an essential component to food democracy—and one that may transform self-help and self-reliance into active citizenship or food democracy.

Oregon Food Bank's Seed to Supper Program has identified "self-reliance" as a main initiative for its program, which correlates with Lawson's (2005) notion of "self-help." This study looks at healthy people and communities as indicators of a successful food system and it also examines the learning garden as a democratic space for building social capital.

\section{Conclusion}

The learning garden has historically served as a prescriptive solution to economic and social inequity. These early examples of learning gardens help us understand the use of urban learning gardens as a space to empower, improve living conditions, increase access to food as well as to help people build self-reliance. Gardens bring nature to urban settings, providing opportunities to build self- 
reliance, and community. Educators have focused on the benefits of experiential place-based learning in learning gardens.

Ecological and sustainability movements and agendas of the $21^{\text {st }}$ century have embraced the learning garden as a contemporary place to foster "stewardship" of the land. The literature portrays a strong tradition of learning gardens that focus on the development of ecological and sustainability curriculums. The continued focus on self-reliance has captured food advocates' attention and learning gardens have become a popular tool to achieve greater food security. Additionally, the learning garden has a potential to make a contribution to community food security and to empower communities to build local food systems that contribute to a stronger food democracy.

It is important to study and document learning gardens because they provide an accessible common space for implementing sustainability goals and food literacy, and offer the potential to increase food security and access to locally grown foods. The next chapter addresses the methodologies and the relevance of communitybased research principles and the impact this ethic has had on this study. 


\section{Chapter 3: Methodology}

\section{Learning Garden Scene 3: Interview at Bell Tower Community Center: Linking up with Community-based Research}

The first Seed to Supper participant interviews began in a community center located in a busy urban neighborhood in Portland, Oregon. The Spanish-speaking participant had finished her first series of the Seed to Supper learning garden classes and she had agreed to interview with me. The Seed to Supper instructor, also a services coordinator for the community center, agreed to translate. After we explained the consent forms and set up the digital recorder, I presented the first question in English, "As a result of taking the Seed to Supper learning garden workshop, have you gained enough experience to grow some of your own fruits and vegetables?" The instructor translated and the participant enthusiastically shared her story about gardening and what the garden workshop had meant to her. Each interview began with the same question, and each interviewee shared a unique story about accessing locally grown food and their connection to food as well as what growing their own food, or the potential to grow their own food, meant to them.

The practice interviews I had conducted in advance did not prepare me for the excitement of the face-to-face interviews with Seed to Supper participants. The intense energy, enthusiasm and challenges of language, interpretation, knowledge levels (in addition to outside distractions) shaped each interview. Bailey (2007) describes the preparation that is required to "frame the interview" (p. 104) and reminds the interviewer that a good interview does not necessarily begin with the 
questions. Setting up the interview, selecting a location and making the space convenient and comfortable impacts the first impressions that often influence the quality of the interview (Bailey, 2007). This scene from the Bell Tower interview, represented weeks preparing the interview questions for approval from the Human Subjects Committee with oversight from my PSU faculty mentor and the Seed to Supper program coordinator-the results were worth the effort. This scene also sets the context for this chapter, which focuses on community-based research using mixed methods approaches in the collection and analysis of data collected over a three-year period (2009 - 2011).

This study is primarily based on the theories and principles of communitybased research. Community-based research often begins with questions that are generated from the local community (Minkler, 2005). Minkler (2005) has described community-based research partnerships as "authentic partnerships...that are locally relevant and community-based" (p. ii3). For this study these partnerships between the researcher, the academy, the faculty mentor and program of study requirements-in addition to the community partner's needs-influenced the process and findings, as well as the analysis and the implications.

This chapter clarifies the on-going interactive processes that community based research utilizes and will address the mixed methods framework for this project including reasons for combining both qualitative and quantitative research. Additionally, this chapter includes a discussion of grounded theory used to support 
community-based research methods, along with a description of the sites observed and population involved in the study.

Other matters considered here are the validity and ethics used in this study as well as the positionality of the researcher. First, I describe how this research project began.

\section{Research Study Background and Development of the Community Partner}

This research project was created in 2009 as part of the McNair Scholars Program at Portland State University. The McNair Scholars program sponsors undergraduate students and pairs them with a faculty mentor to conduct an original research project. My McNair research project later evolved into this Master's thesis, influenced by my participation with the theories and coursework of the Graduate School of Education's Leadership in Sustainability Education program from fall, 2009 through winter, 2012.

The McNair faculty mentor, with whom I collaborated, advised me to develop a community partner and to base my research project on their program needs. During my meeting with a representative from Oregon Food Bank, the representative suggested collaboration with the program coordinator of their Learning Gardens Programs. The initial research question was co-created with the coordinator of the Seed to Supper Program, and with oversight from my McNair faculty mentor, Professor Lisa Weasel, a microbiologist with an interest in feminist community science and social/food justice theories. The focus of the project was an evaluation and analysis of some aspects of the Seed to Supper Program. 
The initial research question-"How do learning gardens help low-income families access fresh locally-grown foods?"-focused on food insecurity and access to local foods. This preliminary question was modified as the process of gathering data led to new information about the learning garden program and due to my participation in the Leadership in Sustainability Education (LSE) program coursework. The revised thesis statement became: the purpose of this study was to discover whether learning gardens such as the Seed to Supper Program increase access to locally grown food and successfully include and empower food insecure people and their communities. Out of this thesis statement came the following set of research questions.

\section{Research Questions}

This study looks at food equity and access within the context of urban agriculture and place-based learning. The basic research questions are: 1) How does the Seed to Supper Program impact food insecure communities and their access to fresh grown and local foods? 2) How are the goals of the Seed to Supper framed/designed and positioned/presented in the served communities? 3) Do these goals accomplish the overarching need for increased food security in urban and peri-urban Portland? 4) Does the Seed to Supper Program improve food literacy, self-reliance and create social capital? 


\section{Research Design and Rationale: Community-based Research Using Mixed Methods}

This study examines the effectiveness of the Seed to Supper program through a community-based research approach using a mixed methods research design. My approach was to establish long-term relationships within the community partners' environment and to gain insights about the Seed to Supper's program approach, and its impact on food insecure populations in order to convey an insider's view of the potential of learning gardens to empower food insecure populations and increase access to locally-grown foods. Using a combination of quantitative and qualitative data collection served both the needs of the community partner and the researcher by illuminating, describing and exploring the nature of garden-based learning on food insecure populations.

Wolcott (2009), stresses the importance of "linking our research to others" (p. 65), and his message is fundamental to this study. One of my goals for this thesis has been to bring the voices of the participants of the Seed to Supper program to the attention of my colleagues in the academy, to public policy makers and to the coordinators of the Oregon Food Bank's Seed to Supper program. The use of community-based research methods in this study balanced the needs of the community partner and positioned the researcher within the learning garden communities to collect data with the collaboration of the community members.

Heffner, et. al., (2003) state the challenges a researcher faces when conducting community-based research: 
The challenge for academic researchers who engage in community-based research is to stay connected to the process long enough to make sure that action for social change is the result of the desired change and work to implement it, but academic researchers who care about community change do more than just prepare a final report and then move on. Embarking on a community-based research project requires a longer-term commitment on the part of the academic researcher and a willingness to enter into the "messy" world of community dynamics (p. 130).

I would not characterize this research study as "messy," but it did require risk taking by becoming involved and staying involved in the community learning garden settings.

Community-based research fits within the theoretical framework of placebased pedagogy as a method to engage with community partners to achieve common goals. For my part, I wanted to discover whether learning gardens helped food insecure communities access locally-grown foods, while the Oregon Food Bank wanted to know if their program was successful in alleviating food insecurity and building self-reliance. These goals intersected in a collaborative and engaged community-based learning environment and research partnership. Because of the place-based nature of the Seed to Supper Program and the dynamic nature of community-based research, a mixed quantitative and qualitative research methods approach best addressed the questions inherent in this study. 
The quantitative aspect of the study design included an evaluative survey distributed by the Oregon Food Bank voluntary instructors following the Seed to Supper classes. This quantitative method provided statistical evidence about the impact of the learning garden, which was the prime focus of the community partner, The Oregon Food Bank. The qualitative aspect the study included fieldwork techniques of observation and field notes, semi-structured interviews, and interactive participation by the researcher, with the community partner, the Seed to Supper learning garden sites.

This mixed-methods design allowed for a more collaborative and adaptive research environment. Mixed methods design includes the "use [of] mixed data (numerical and text) and alternative tools-[field work: including observational notes and interviews], including developing a grounded theory" (Tashakkori \& Teddue, 2003, p. 711). Tashakkori \& Teddue (2003) state that this type of research design allows for collection of data "concurrently or sequentially, and involves integration of the data at more than one stage of the research process" (p. 711). The mixed methods approach allows for community-based researchers to collaboratively make changes, using critical and reflective thinking and analysis (Heffner, et. al., 2003). "This interaction between investigator and the subjects of the investigation requires dialogue, careful communication, and a certain degree of trust that takes time to develop" (Heffner, et. al, 2003, p. 127).

A welcoming and long-term relationship developed based on careful investigation and open communication between the community partners and the 
researcher. This provided the researcher with an insider's perspective, paving the way for thick descriptions of the learning garden scenes.

This study also made use of ethnography in its qualitative research methods. Ethnography is the study of people and their culture; it is also a method used in qualitative research (Tashakkori \& Teddue, 2003). Because of the nature of community-based learning gardens--the garden-based programs and the settings they reside in--ethnographic data collection, observation, interviews and relationship building became inevitable features of this study. Bernard, (2000) states that ethnography "is understanding ... people's lived experiences" (p. 348). This method proved invaluable in the garden settings and as Bernard suggests, a few "key informants" articulate their knowledge and position to describe a culture or place - this type of information collection is not from an "unbiased sample of people" (p. 344). The interviews conducted for this research project led to this type of ethnographic discovery of key participants who were integral to the gardening communities I examined, and critical to me as the researcher and to the discoveries I made. Early in the process of the interviews, it was clear that in each community site I visited, eventually a key participant would emerge to guide me in my research process, revealing the internal workings of the garden, its community and culture. As a result of this collaboration, I learned that the process of assimilating into the learning garden communities would take time and my place as a researcher would naturally evolve. As Heffner, et. al, (2003) state: 
University people have to earn the right to contribute. Community organizations and community members often view academics with suspicion or skepticism. It takes time for trust to develop, and learning to communicate clearly and honestly is sometimes a challenge (p. 137).

As this study progressed, I became part of the community landscape-both in the offices of the community partner, Oregon Food Bank, and at the learning garden sites. The field observations for this project were handwritten notes in a journal format and photo journals of the gardens kept throughout the study time period, June, 2009 through the Fall of 2011. The gardens and the people who worked in the gardens became a part of my personal experience within the research process. These recordings are reflected in the "Learning Garden Scenes 1-5" and are further developed in the results found in chapter 4 .

These real life settings provided opportunities to develop thick descriptions about the impact of the learning gardens on the individuals and in the larger context of the community settings. By including both quantitative and qualitative methods, the researcher and community partner gleaned a realistic description the learning garden activities over time. These combined methods of observations provided deeper reflections about the impact these activities had on the participants and their communities.

Research Sites

This study was based on research over a three-year period (2009-2011) in the context of garden-based learning that took place within the Oregon Food Bank's 
Seed to Supper program classes situated in classrooms and settings located within the participants' community. These place-based communities were situated throughout the Portland metro regions and included Multnomah, Clackamas and Clark counties. The classroom and garden sites were located within public housing authorities, community centers, senior centers, Head Start program locations and other hunger-relief agencies.

Table 1 describes the sites where the study took place. The Seed to Supper program partners with local (county and state) social service agencies to host and teach basic gardening classes to populations being served by these agencies and by the Oregon Food Bank's emergency food programs. The program locates in the communities where participants live and/or receive social services.

These sites hosted Seed to Supper gardening classes, workshops and information fairs to aid participants in growing fresh produce, preparing nutritious foods, and learning new life skills. The survey and fieldwork, including, observations, interviews and photography took place at the sites in Table 1. The real names of locations have been changed. 
Table 1

Seed to Supper Sites for survey and fieldwork

\begin{tabular}{|c|c|c|c|}
\hline \multicolumn{4}{|c|}{ Seed to Supper Sites } \\
\hline Name & Type & Services & $\begin{array}{l}\text { Learning Garden } \\
\text { Description }\end{array}$ \\
\hline Riverside Court & Senior Center & $\begin{array}{l}\text { Loaves and Fishes } \\
\text { Site }\end{array}$ & $\begin{array}{l}\text { No learning garden } \\
\text { on site - uses } \\
\text { various gardens } \\
\text { throughout the } \\
\text { Metro region }\end{array}$ \\
\hline Cascade Views & $\begin{array}{l}\text { Food Pantry } \\
\text { (Faith-based) }\end{array}$ & $\begin{array}{l}\text { Emergency Food } \\
\text { boxes, misc. social } \\
\text { services }\end{array}$ & $\begin{array}{l}\text { Large learning } \\
\text { garden - } 30 \\
\text { participants }\end{array}$ \\
\hline Brookplace & Public Housing site & $\begin{array}{l}\text { Community center, } \\
\text { social services } \\
\text { coordinator for } \\
\text { county }\end{array}$ & $\begin{array}{l}\text { Large Community } \\
\text { garden utilizing } \\
\text { raised beds. Large } \\
\text { blueberry field } \\
30 \text { participants }\end{array}$ \\
\hline Forest Hills & Public Housing Site & $\begin{array}{l}\text { Social Services } \\
\text { Coordinator for } \\
\text { county }\end{array}$ & $\begin{array}{l}\text { Large Community } \\
\text { garden with } \\
\text { children's garden, } \\
\text { community patch } \\
\text { and individual } \\
\text { raised beds } \\
30 \text { participants }\end{array}$ \\
\hline Bell Tower & Community Center & $\begin{array}{l}\text { Social Services } \\
\text { Coordinator for } \\
\text { county }\end{array}$ & $\begin{array}{l}\text { Container Garden } \\
\text { site on patio }\end{array}$ \\
\hline
\end{tabular}

The survey was distributed at all of the Seed to Supper sites listed in Tables $1 \& 2$.

Fieldwork was conducted at sites listed in Table 1 . Table 2 lists sites that only participated in the survey. 
Table 2

Survey sites only

\begin{tabular}{|c|c|c|}
\hline $\begin{array}{l}\text { Seed to Supper } \\
\text { Sites }\end{array}$ & Type & Services \\
\hline $\begin{array}{l}\text { Lakeview } \\
\text { Correctional } \\
\text { Facility }\end{array}$ & Correctional Facility & $\begin{array}{l}\text { Incarcerated } \\
\text { individuals }\end{array}$ \\
\hline $\begin{array}{l}\text { Mountain View } \\
\text { Treatment Center }\end{array}$ & $\begin{array}{l}\text { Drug Recovery } \\
\text { Center }\end{array}$ & $\begin{array}{l}\text { Mental health, } \\
\text { alcohol and drug } \\
\text { abuse recovery } \\
\text { treatments }\end{array}$ \\
\hline The Tower & Senior Center Home & Housing \\
\hline Head Start & $\begin{array}{l}\text { Early pre-school } \\
\text { education facility }\end{array}$ & $\begin{array}{l}\text { Educational } \\
\text { programs }\end{array}$ \\
\hline Our Lord & Faith Based Facility & $\begin{array}{l}\text { Social Services } \\
\text { support }\end{array}$ \\
\hline The Way & Faith Based Facility & $\begin{array}{l}\text { Social Services } \\
\text { support }\end{array}$ \\
\hline Tribal Nation & $\begin{array}{l}\text { Native American } \\
\text { Reservation }\end{array}$ & $\begin{array}{l}\text { Social Services } \\
\text { center }\end{array}$ \\
\hline Youth Center & $\begin{array}{l}\text { Youth Center \& } \\
\text { Shelter }\end{array}$ & $\begin{array}{l}\text { Emergency services } \\
\text { for youth }\end{array}$ \\
\hline $\begin{array}{l}\text { Urban Homeless } \\
\text { Shelter }\end{array}$ & Homeless Shelter & $\begin{array}{l}\text { Emergency services } \\
\text { for homeless }\end{array}$ \\
\hline Religious Charities & Faith Based Facility & $\begin{array}{l}\text { Social Services } \\
\text { support }\end{array}$ \\
\hline $\begin{array}{l}\text { Housing Authority } \\
\text { of Portland }\end{array}$ & $\begin{array}{l}\text { City Housing } \\
\text { Department }\end{array}$ & Housing \\
\hline $\begin{array}{l}\text { The Place Mental } \\
\text { Health }\end{array}$ & $\begin{array}{l}\text { Mental Health } \\
\text { Facility }\end{array}$ & $\begin{array}{l}\text { Mental Health } \\
\text { Support Services }\end{array}$ \\
\hline $\begin{array}{l}\text { Metro Family } \\
\text { Services }\end{array}$ & $\begin{array}{l}\text { Multnomah County } \\
\text { Family Service }\end{array}$ & $\begin{array}{l}\text { Social Services } \\
\text { Support }\end{array}$ \\
\hline
\end{tabular}

Research Participants

The research participants self-selected to take Seed to Supper classes and volunteered to participate in this study. There was no pressure to actively take part in any aspect of the study. Because volunteers teach the Seed to Supper program, 
the onsite staff coordinators decide on the participant selection process. This is explained in greater detail in the section on data collection.

In order to participate in a Seed to Supper workshop, both survey and interview populations qualified for food bank services and were pre-approved by the various research site staff coordinators. Eighty-one percent of participants surveyed from the Seed to Supper Program were earning less than $200 \%$ of the poverty level. Ethnicity was not addressed in the learning garden survey because the community partner, Oregon Food Bank, conducts its own bi-annual survey. The survey, Oregon Hunger Factors, provided ethnicity and other data represented here (OFB, 2008). For this reason, the Seed to Supper survey does not collect data about ethnicity, or age, as the demographic composition of the Seed to Supper participants correlates with the general demographic data for those receiving an Oregon Food Bank emergency food box-74\% White, 14\% Hispanic, 3\% Native American, 2\% Black and mixed - 4\% (Profiles of Hunger \& Poverty in Oregon, p. 3, 2008). See Figure 1. 
Figure 1. Demographics for OFB Seed to Supper Survey Respondents

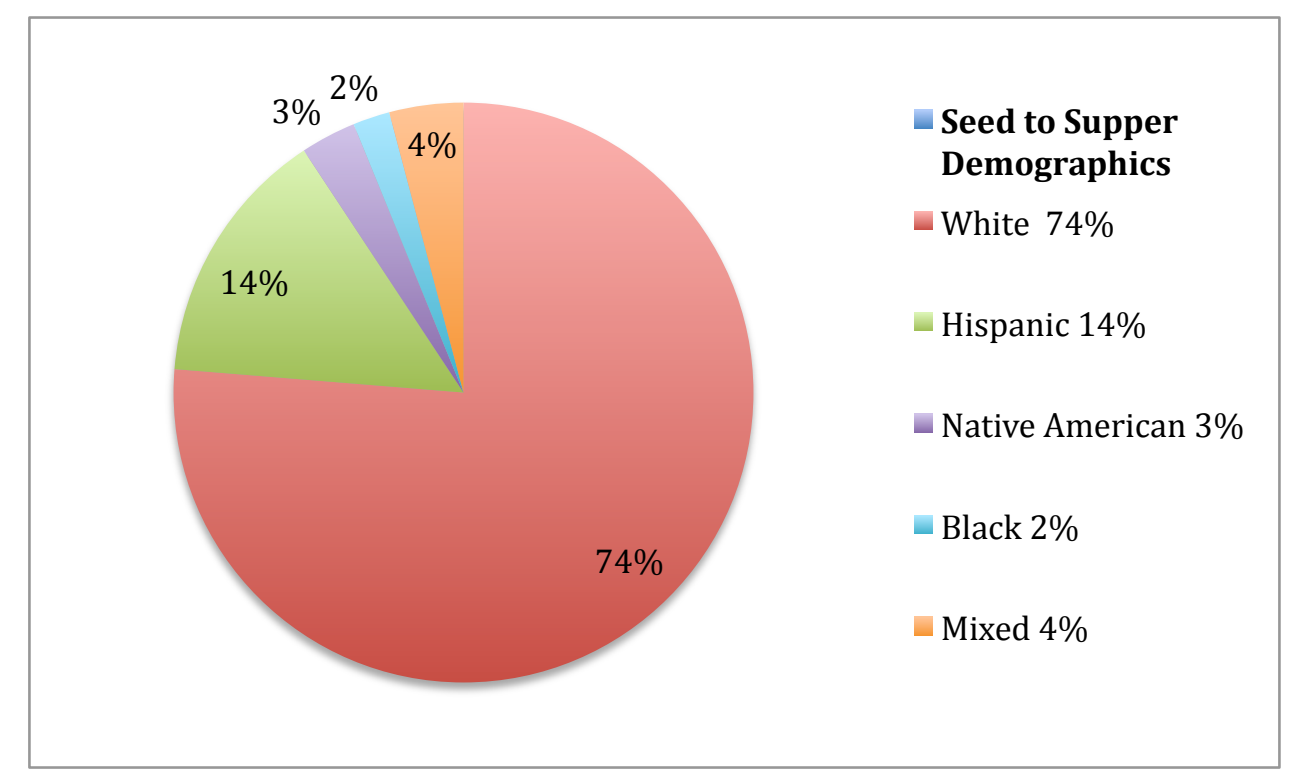

Oregon Hunger Factors: 2008

The interviewees included 15 females and 5 males for a total of 20

interviewees. The interviewees ranged from college-aged to retirement-aged (the

Seed to Supper classes are primarily offered to adults). There were three categories of interview groups. Nine of the interviewees were Seed to Supper participants, three were Seed to Supper instructors and eight of the interviewees were key community members and/or leaders in the Portland region. The community members often played several roles, including county staff coordinators for the sites, as well as volunteers for the Seed to Supper Program. Other community leaders were active in food insecurity policy, community garden programs and education in the Portland region. The "Key Participants" are informants in the research process, collaborating as guides to the researcher (Bernard, 2000; Bailey, 
2007). The key participants played a larger role in the research process at the sites.

These key participants are highlighted in bold in Tables 3, 4, \& 5 .

The demographics available and category of participation are listed and described in the tables below. The names have been changed to protect the interviewees' confidentiality.

To understand the various levels of participants and interviewees, the following tables are divided into three groups: group 1 represents Seed to Supper participants, group 2 represents Seed to Supper Instructors and group 3 represents both community members and leaders as described previously.

Table 3

Interview participant information - Group 1: Seed to Supper Participants

\begin{tabular}{llllll}
\hline Name & Group 1 & Gender & Site & Role & Employed \\
\hline $\begin{array}{l}\text { Becky- key } \\
\text { participant }\end{array}$ & $\begin{array}{l}\text { Seed to Supper } \\
\text { Participant }\end{array}$ & Female & Brookplace & $\begin{array}{l}\text { Community } \\
\text { member \& } \\
\text { volunteer }\end{array}$ & \\
David & $\begin{array}{l}\text { Seed to Supper } \\
\text { Participant }\end{array}$ & Male & Riverside & $\begin{array}{l}\text { Community } \\
\text { member, } \\
\text { volunteer }\end{array}$ & \\
Mary & $\begin{array}{l}\text { Seed to Supper } \\
\text { Participant }\end{array}$ & Female & Brookplace & $\begin{array}{l}\text { Community } \\
\text { member }\end{array}$ & \\
Alfred & $\begin{array}{l}\text { Seed to Supper } \\
\text { Participant }\end{array}$ & Male & Brookplace & $\begin{array}{l}\text { Community } \\
\text { member }\end{array}$ & x \\
Bill & $\begin{array}{l}\text { Seed to Supper } \\
\text { Participant }\end{array}$ & Male & Brookplace & $\begin{array}{l}\text { Community } \\
\text { member }\end{array}$ & \\
Louise & $\begin{array}{l}\text { Seed to Supper } \\
\text { Participant }\end{array}$ & Female & Brookplace & $\begin{array}{l}\text { Community } \\
\text { member }\end{array}$ & \\
Hillary & $\begin{array}{l}\text { Seed to Supper } \\
\text { Participant }\end{array}$ & Female & Riverside & $\begin{array}{l}\text { Community } \\
\text { member, }\end{array}$ & x \\
& $\begin{array}{l}\text { Seed to Supper } \\
\text { Participant }\end{array}$ & Female & Bell Tower & $\begin{array}{l}\text { Volunteer } \\
\text { Participant } \\
\text { only }\end{array}$ & \\
Alicia & $\begin{array}{l}\text { Seed to Supper } \\
\text { Participant }\end{array}$ & Female & HeadStart & $\begin{array}{l}\text { Community } \\
\text { volunteer }\end{array}$ & x \\
\hline Terry & & & & & \\
\hline
\end{tabular}


Table 4

Interview participant information - Group 2: Seed to Supper Instructors

\begin{tabular}{|c|c|c|c|c|c|}
\hline Name & Group 2 & Gender & Site & Title & Employed \\
\hline Raymond* & $\begin{array}{l}\text { Seed to } \\
\text { Supper } \\
\text { Instructor }\end{array}$ & Male & Riverside & $\begin{array}{l}\text { Services } \\
\text { Coordinator }\end{array}$ & $\mathrm{x}$ \\
\hline Susan* & $\begin{array}{l}\text { Seed to } \\
\text { Supper } \\
\text { Instructor }\end{array}$ & Female & Bell Tower & $\begin{array}{l}\text { Services } \\
\text { Coordinator }\end{array}$ & $\mathrm{x}$ \\
\hline Linda & $\begin{array}{l}\text { Seed to } \\
\text { Supper } \\
\text { Instructor }\end{array}$ & Female & Lakeview & Volunteer & \\
\hline
\end{tabular}

* Both of these instructors were also paid staff members and worked at the site.

Table 5

Interview participant information - Group 3: Community members and leaders

\begin{tabular}{|c|c|c|}
\hline Name & Role & Location \\
\hline Elizabeth & $\begin{array}{l}\text { Assistant to Elected } \\
\text { Oregon Official }\end{array}$ & Washington, DC \\
\hline $\begin{array}{l}\text { Helen - key } \\
\text { participant }\end{array}$ & Site Coordinator & Clackamas County \\
\hline Braden & $\begin{array}{l}\text { Major Garden Program } \\
\text { Coordinator }\end{array}$ & Multnomah County \\
\hline Melissa & $\begin{array}{l}\text { Director, Community } \\
\text { Gardens Program }\end{array}$ & Multnomah County \\
\hline Carol & Elected County Official & Multnomah County \\
\hline Misty & Garden Coordinator & Multnomah County \\
\hline $\begin{array}{l}\text { Anna - key } \\
\text { participant }\end{array}$ & Program Coordinator & Tri-County area \\
\hline $\begin{array}{l}\text { Rachel - key } \\
\text { participant }\end{array}$ & Program Coordinator & Tri-county area \\
\hline
\end{tabular}

Data Collection

The data collection phase of the study began in Summer 2009 after the approval from the Portland State University Human Subject Review Committee. The data collection phase had two parts: a quantitative evaluative survey instrument cocreated with Oregon Food Bank, and a qualitative component which included a set 
of interview questions, observations, and participation designed by the researcher to further understand the issues of food insecurity and access to locally-grown foods. Both the survey and interview questions were created and submitted to the Human Subjects Review Committee prior to beginning the study.

The ethical context of this research project deserves some clarification. The true names and places have remained anonymous to protect identities and specific gardens. However, some aspects of this project, in terms of implementation as a community-based research project, have involved sites that have cooperated jointly with PSU University activities for classes, demonstrations and other community spirited activities. In this environment, some places have been revealed with permission from the participants and key community members. Nowhere in this paper do the true names or places appear, only references to the activities and general descriptions of where the activities took place. However, as a small community it is most likely that some identification is possible.

Quantitative: Survey Design and Implementation

Design \& Sample Questions

The survey was co-designed with the coordinator of the Seed to Supper Program with additional input from my faculty mentor. Using a combination of forced-choice questions using Likert-scaled scoring, in combination with openended questions, the survey was approved by late Spring, 2009 (see Appendix A: Seed to Supper Survey). The Likert-scaled questions were designed to specifically 
assess the impact of the Seed to Supper program on access to fresh foods as shown below in Table 6, as well as program evaluation.

Table 6 reflects the research questions, with examples of survey questions that addressed these four questions.

Table 6

Research Questions and examples of survey questions

\begin{tabular}{|c|c|c|}
\hline Research Questions & $\begin{array}{l}\text { Survey question: Lickert } \\
\text { Scale of 1-3 }\end{array}$ & $\begin{array}{l}\text { Open-ended question or } \\
\text { forced choice }\end{array}$ \\
\hline $\begin{array}{l}\text { 1. How does the Seed to Supper } \\
\text { Program impact food insecure } \\
\text { communities and their access to } \\
\text { fresh grown and local foods? }\end{array}$ & $\begin{array}{l}\text { Survey Q2. } \\
\text { I have gained enough } \\
\text { experience to grow some of } \\
\text { my own fruits and vegetables. }\end{array}$ & $\begin{array}{l}\text { Survey Q.15. Please share } \\
\text { a story about your } \\
\text { gardening as result of this } \\
\text { workshop. } \\
\text { Q. } 11 \text { How often do you } \\
\text { eat fresh fruits and } \\
\text { vegetables? }\end{array}$ \\
\hline $\begin{array}{l}\text { 2) How are the goals of the Seed } \\
\text { to Supper framed/designed and } \\
\text { positioned/presented in the } \\
\text { served communities? * }\end{array}$ & $\mathrm{N} / \mathrm{A}$ & $\mathrm{N} / \mathrm{A}$ \\
\hline $\begin{array}{l}\text { 3) Do these goals accomplish the } \\
\text { overarching need for increased } \\
\text { food security in urban and peri- } \\
\text { urban Portland? } \\
\text { (This question addresses } \\
\text { barriers) }\end{array}$ & $\begin{array}{l}\text { Survey Q7. I currently use a } \\
\text { community garden space. } \\
\text { Survey Q8. I have a garden in } \\
\text { my yard. }\end{array}$ & $\begin{array}{l}\text { Survey Q13. What } \\
\text { prevents you from } \\
\text { obtaining fresh fruits and } \\
\text { vegetables or growing } \\
\text { your own? } \\
\text { Forced choices: } \\
\text { Cost, availability, garden } \\
\text { space or no time to garden }\end{array}$ \\
\hline $\begin{array}{l}\text { 4) Does the Seed to Supper } \\
\text { Program improve food literacy, } \\
\text { self-reliance and create social } \\
\text { capital? } \\
\text { *Research question } 2 \text { was designed t } \\
\text { community participants and commu }\end{array}$ & $\begin{array}{l}\text { Survey Q3. } \\
\text { I grow some of my own } \\
\text { produce. } \\
\text { be answered by the interview c } \\
\text { ity leaders - see Table } 6 \& 7 \text {. }\end{array}$ & $\begin{array}{l}\text { Survey Q15. Please share } \\
\text { a story about your } \\
\text { gardening as a result of } \\
\text { this workshop. } \\
\text { uestions with instructors, ke }\end{array}$ \\
\hline \multicolumn{3}{|c|}{ In addition to the research questions, the main goal of the survey was to } \\
\hline assess the learning garden $\mathrm{p}$ & ram. The following surv & uestions are good \\
\hline
\end{tabular}


14. What would you recommend changing or adding to improve these workshops?

15. Please share a story about your gardening as a result of this workshop.

16. Do you need more information or advice to grow a garden? If yes, please explain

17. Where do you get your gardening questions answered?

The survey's main purpose served the needs of the community partner in providing suggestions for program improvement as well as testimonial statements about the successes of the program. Additionally, the survey identified the barriers affiliated with food insecurity.

\section{Survey Implementation}

Survey implementation began in the June, 2009 and continued through October, 2011. Oregon Food Bank's staff and volunteers administered the survey to the Seed to Supper participants while they were at the Seed to Supper research sites (see Tables $1 \&$ 2). Seed to Supper participants self-selected and were not required to complete the survey. When needed, a translator was available to help with translation of the survey and to answer questions. There were 212 surveys returned over the three-year period, June 2009 through October, 2011. The data was entered into Qualtrics for statistical and comparison reporting. 
Qualitative: Interview Design and Process

Interview Design: The Questions

Qualitative interviews provided a method for gaining not only answers to the initial question regarding access to locally grown foods, but also a fuller understanding of access barriers and program success. To gain more detailed information about access to locally grown foods, the interview questions expanded upon the survey questions to address the four research questions. Table 7 outlines sample interview questions linked to research questions.

\section{Table 7}

Sample Seed to Supper Participant interview questions linked to research questions

\begin{tabular}{|c|c|c|}
\hline Research Questions & Interview questions yes/no: & $\begin{array}{l}\text { Open-ended question or } \\
\text { multiple choice }\end{array}$ \\
\hline $\begin{array}{l}\text { 1. How does the Seed to Supper } \\
\text { Program impact food insecure } \\
\text { communities and their access to } \\
\text { fresh grown and local foods? }\end{array}$ & $\begin{array}{l}\text { Interview Q2. } \\
\text { I have gained enough } \\
\text { experience to grow some of } \\
\text { my own fruits and vegetables. } \\
\text { Q2. As a result of taking a } \\
\text { learning garden workshop, do } \\
\text { you eat more fresh-grown } \\
\text { produce? If yes, what kinds, } \\
\text { did you grow or purchase } \\
\text { them? }\end{array}$ & $\begin{array}{l}\text { Interview Q.14. } \\
\text { Is there anything you } \\
\text { would like to share about } \\
\text { your Seed to Supper } \\
\text { experience? } \\
\text { Q. } 4 \text { How has this } \\
\text { workshop changed the } \\
\text { kind of food you eat? }\end{array}$ \\
\hline $\begin{array}{l}\text { 2) How are the goals of the Seed } \\
\text { to Supper framed/designed and } \\
\text { positioned/presented in the } \\
\text { served communities? }\end{array}$ & & $\begin{array}{l}\text { Interview Q8. } \\
\text { What would you } \\
\text { recommend changing or } \\
\text { adding to improve these } \\
\text { workshops? } \\
\text { Interview Q.14. } \\
\text { Is there anything you } \\
\text { would like to share about } \\
\text { your Seed to Supper } \\
\text { experience? }\end{array}$ \\
\hline $\begin{array}{l}\text { 3) Do these goals accomplish the } \\
\text { overarching need for increased } \\
\text { food security in urban and peri- } \\
\text { urban Portland? (This question } \\
\text { addresses barriers) }\end{array}$ & $\begin{array}{l}\text { Interview Q1. } \\
\text { As a result of taking a learning } \\
\text { garden workshop, have you } \\
\text { gained enough experience to } \\
\text { grow some of your fruits and }\end{array}$ & \\
\hline
\end{tabular}


vegetables? If yes, explain, If

no, why?

4) Does the Seed to Supper Program improve food literacy, self-reliance and create social capital?
Interview Q3.

Were you growing fruits and vegetables before the workshop, or after the workshop?
Interview Q9.

Please share a story about your gardening or meal experience as a result of this workshop.

The qualitative semi-structured and open-ended interviews were based on a series of fourteen questions derived from the survey questions (see Appendix B: Seed to Supper Participant Interview questions). These interview questions represented a series of yes/no questions, multiple choice and open-ended questions. All of these questions gave the Seed to Supper interviewees the opportunity to expand on their experiences in the classes or workshops. They also examined closely the barriers to food security, limitations participants' faced in gardening, and specifically what was important to them regarding access to locally grown foods.

A separate set of interview questions was designed for the key community members and instructors that related to the research questions, and specifically question 2, "How are the goals of the Seed to Supper framed and presented in the served communities?" As the interviews progressed, interviewees addressed the goals of the Seed to Supper program and its design within the context of their involvement in learning garden programs or specifically within context of the Seed to Supper program. 
Table 8

Community Members/Leaders \& Seed to Supper Instructors interview questions

\begin{tabular}{|c|c|c|}
\hline \multicolumn{3}{|c|}{ Community Members and leaders - Interview questions } \\
\hline $\begin{array}{l}\text { Question } 1 \text { ) } \\
\text { How do community garden } \\
\text { educational programs help low- } \\
\text { income families access locally } \\
\text { grown foods? }\end{array}$ & $\begin{array}{l}\text { Question 2) } \\
\text { How effective are Portland } \\
\text { educational programs in } \\
\text { achieving this goal? }\end{array}$ & $\begin{array}{l}\text { Question 3) } \\
\text { What are your suggestions for } \\
\text { improving low-income families } \\
\text { access to fresh locally grown } \\
\text { foods? }\end{array}$ \\
\hline \multicolumn{3}{|l|}{ Seed to Supper Instructors } \\
\hline $\begin{array}{l}\text { Question 1) } \\
\text { How does the Seed to Supper } \\
\text { Program help families access } \\
\text { fresh locally grown foods? }\end{array}$ & $\begin{array}{l}\text { Question 2) } \\
\text { In your opinion: How effective } \\
\text { is the Seed to Supper Program } \\
\text { in accomplishing its goals? }\end{array}$ & $\begin{array}{l}\text { Question 3) } \\
\text { What are your suggestions for } \\
\text { improving the Seed to Supper } \\
\text { program impact on low-income } \\
\text { families access to fresh locally } \\
\text { grown foods? }\end{array}$ \\
\hline
\end{tabular}

Interview Implementation: Framing the Interviews

The interviewees reflected the same three groups used to represent the group categories and demographics in the survey. Due to limited time and resources, the Human Subjects Review Committee suggested that I interview less than 20 Seed to Supper program participants and community members, (see Tables 3, 4 \& 5), thereby limiting the number of interviews to a total of 18 .

A good interview does not necessarily begin with the questions (Bailey, 2007). Bailey (2007) stresses the time spent nurturing relationships as critical to one's data collection as the time spent designing the questions. Attention to details includes where the interview will take place, how to use courtesy, what ethics are important to the population you are interviewing, how the interviewer can insure rapport, and Bailey suggests how the interview should be brought to closure (Bailey, 2007). These are all important aspects of the interview process and 
implementation. The types of interview techniques must also be considered. These include how to get started, who leads the questioning, how to probe the interviewee, and learning how to interview (Bernard, 2000).

For this study, I used a semi-structured interview process using the same set of questions for each group of interviewees. However, with semi-structured format, there is flexibility to allow the process, or the flow of the interview to unfold. For example, several questions may be answered in one response, and require some reordering of the questions to allow for an organic development. Using an interpretive paradigm of inquiry or inductive process as used in grounded theory, semi-structured interviews use a formal structure with flexibility (Bernard, 2000; Bailey, 2007).

In order to practice and refine the interview process, I set up three pilot semi-structured interviews. Following all of the protocols required by my human subjects application, I interviewed three gardeners. One was a home gardener, one an activist gardener, practicing gorilla gardening on the eastside of Portland. The last interview was with a Portland State University gardener active in the student community garden on campus. These interviews provided an opportunity to use the digital recorder, practice the fourteen interview questions and feel my way through various techniques of introductions, closures, listening and refraining from interrupting the interviewees, and prompting them to talk more about a question. The following section describes how the interviews were conducted for each of the interview groups. 
The majority of interviewees were participants of the Seed to Supper

program - Group 1. Participants were contacted through electronic mail, a personal letter or by a request from the Seed to Supper instructor asking if they wished to participate in an interview about their gardening experiences. Once they agreed to an interview, I would contact the participant and set up an appointment and location for the interview. The interviews lasted 30 minutes and were conducted within the participant's garden or community center. When possible, the participants selected a location from an option of choices. Once the consent forms were signed and the digital recorder set-up, the interview took place. I took notes and prompted the interviewees using the questions.

I followed a similar process for the interviews with Seed to Supper instructors (Group 2) and community members and leaders (Group 3). However, the questions were open-ended and focused on program effectiveness. These interviewees were selected for their interest or participation in learning garden programs. However, in many instances key participants in the study recommended I interview people that they knew or with whom they had experience with; this process that is referred to by social scientists as "snowball sampling" (Bernard, 2000). This phenomenon was exciting and provided access to several active community members and leaders.

Although the interviews were semi-structured, the community leaders and key community members, as anticipated, spoke in an open-ended manner and in general about their role in addressing food insecurity in Portland. The Seed to 
Supper instructors also were given a lot of latitude to discuss what they felt was important about the program.

Participation in the interview process was voluntary and each interviewee was notified of their right to end the interview at any time through the informed consent process mandated by the Internal Review Board responsible for graduate research involving human subjects. Wolcott (2009) advises interviewers to, "pay as much attention to your own words as you do to the words of your respondents" (p. 112). This advice is paramount for a researcher who seeks to gain insights into a community or culture - through the interview process.

Participant and Nonparticipant Observation, Notetaking, Journaling and Photographic Fieldwork

Bailey (2007) informs student researchers that " just as relationships are deeply embedded... in our experiences, field relationships similarly affect the field research process"(p. 73). The bulk of my observational fieldwork at the learning gardens was overt and unstructured. In general, the people of the community knew I was there to make observations about the role of the garden in their community. My participation was minimal. However, after three years, it was clear I was noticed and acknowledged by many members of the community. Bailey states, "the decision whether to participate or observe, or perhaps to do some of both, is affected by the paradigm and the tradition of inquiry being used" (2007, p. 81). In communitybased research, it is expected that on some level the researcher will participate (Minkler, 2005). 
During the second year of the study, I attended a Seed to Supper Instructor training and began volunteering as an instructor for the Seed to Supper program. In this capacity, I received first-hand knowledge about the curriculum, the training process for the instructors, and what the Oregon Food Bank Seed to Supper Program coordinators expected for the program. From this inside vantage point, I became a participant in the program-as well as a researcher. My techniques for participant observation were simple: I kept copious notes and journals, during and after trainings, or workshops or presentations I attended or was giving. I assisted one of the Seed to Supper instructors during a six-week gardening session at Brookplace, and volunteered for several Fix-It (informational) Fairs. During this experience, I did not bring my camera or notebook, I was there to teach or provide information. It was a humbling and transformational learning experience for me as a garden educator.

The following methods were used during my fieldwork as a nonparticipant researcher: Journal keeping: Before each visit to a site, or before an interview, I took preparatory notes about what I anticipated during my visit. I would either take notes during an interview or if I was simply visiting a garden site, I would sit in the garden areas and write down my observations, and make notes about aspects of the garden that had changed from season to season. My observations were often focused on place-based details or aspects of the community that had changed.

Photography: During my visits, I always brought my camera and photographed the gardens, the garden art, the surrounding grounds, plants and 
other things that stood out in the landscape. These photos became invaluable journals about the nature of the learning gardens. The photos gave me chronicle of the events, seasons and various styles of gardening techniques found in the community garden sites.

These fieldwork techniques provided insight into the life of the garden and the gardeners. The culture and experience came to life through these sessions and are reflected throughout my thesis and were an important element of data collection in addition to surveys and interviews.

Data Analysis

As formidable as folders of survey results, notes, journals, photos and transcribed interviews can be, the process of organizing the data and identifying patterns and trends is the heart of the research process. A system for organizing the data is invaluable for tracking and coding the data.

I used grounded theory as a framework for data analysis, which shaped the discoveries and emergent theories. Grounded theory is an analytical qualitative social research theory and method that provides guidelines to assist the researcher in studying social issues using inductive reasoning from observation (Bryant \& Charmaz, 2007). Grounded theory also serves as a data collection and a data analysis system that allows for an emergent process of the discovery, which allows the theoretic frameworks to be revealed in the research process (Charmaz, 2003). Often grounded theorists will begin data analysis early in the data collection process, thereby simultaneously collecting and analyzing the data in order to allow 
for emergent patterns, interests and discoveries. This pattern of analysis can be repeated and may redirect the questions and queries that initially motivate the researcher (Charmaz, 2003). From a theoretical point of view, grounded theory describes the discovery process for emergent theories that I used to conduct this mixed-methods research project. As Charmaz (2003) suggests, I created a body of field notes to compare with interview notes. I coded the notes to identify similar categories, concepts and trends. After creating a large body of ideas, I created tables categorizing the concepts and cross-referencing all these to the surveys and my own observations. This took place during the first round of interviews in August 2009 and I repeated the process in the winter of 2012.

\section{Qualitative Data}

Grounded theory played a role in the interpretation of the fieldwork methods including note taking and interviews. As data were collected, each interview was transcribed and coded for patterns and trends as well as similarities and differences among participants, instructors and key community players (Bernard, 2000). Initially, for the preliminary study (the McNair study), a set of patterns and trends were identified and catalogued in order to address the first research question regarding the impact of the learning gardens on low-income families access to locally grown foods. For the purpose of this thesis, the interviews were re-analyzed and coded with the four main research questions in mind.

In addition, the coding was expanded to include new terminology introduced by the Leadership for Sustainability (LSE) program of study regarding sustainability, 
garden-based pedagogy and food literacy, food justice and food democracy. By combining the previous codes from the preliminary study and the LSE terminology, I continued with grounded theory methods of coding. This flexible and resilient coding method, as formulated by Glaser and Strauss in 1967, provides the researcher with a set of relevant predictions, explanations, interpretations and applications to follow. This sociological method of interpretation and coding process has contributed to the creative interpretative unfolding of this research project. Quantitative Data

The early survey data were recorded using an excel spreadsheet. During the second year, the old surveys were re-entered along with the new incoming surveys into a Qualtrics statistical analysis program. Qualtrics is an online Internet survey program that allows for easy inputting of original data. It also provides a complete statistical reporting system, and can be exported for charts, figure and summaries. This program is ideal for survey design and implementation, but in this study, the population was not equipped for this type of distribution. Qualtrics was strictly used for the analysis aspect. The following (Figure 2) illustrates the reporting capability and results of survey question number 1, "This workshop taught me something that I will be to use in my garden." 
Figure 2. Example of Survey Question with Statistical Analysis
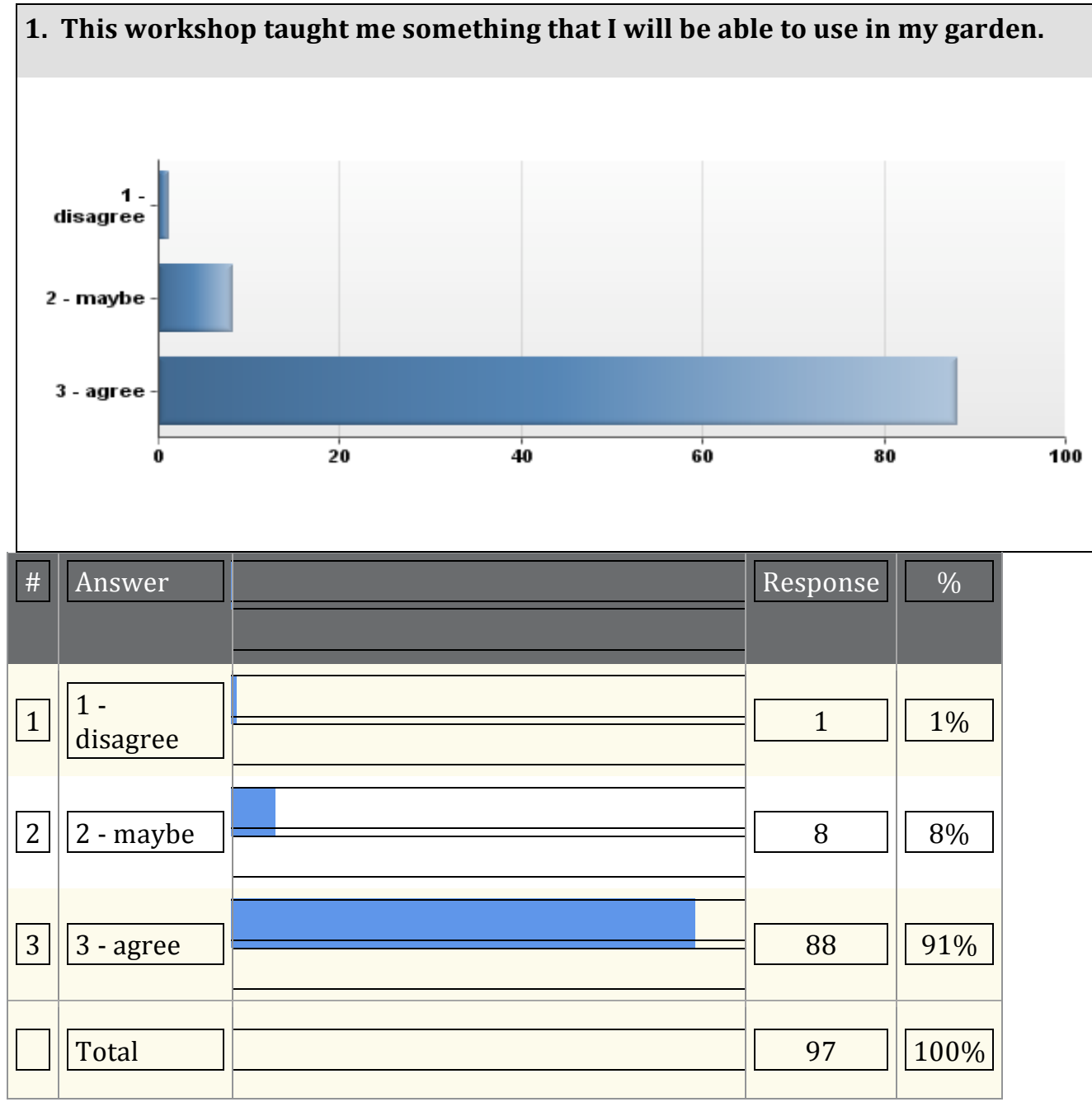

\begin{tabular}{|l|r|}
\hline Statistic & Value \\
\hline Min Value & 1 \\
\hline Max Value & 3 \\
\hline Mean & 2.90 \\
\hline Variance & 0.11 \\
\hline Standard Deviation & 0.34 \\
\hline Total Responses & 97 \\
\hline
\end{tabular}


Figure 2 illustrates the capacity that Qualtrics supplies to collate the survey responses and the options for presenting statistical responses. This program supplied a program assessment to Oregon Food Bank staff.

\section{Validity}

The issue of validity is critical to mixed methods research. This study was informed by several practices for trustworthiness and reliability. Guba's, (1981), criteria for validity as presented by Gay, Mills, \& Airasian (2009), recommends a number of strategies for accomplishing validity. Below, I have outlined the primary strategies used for this study as described by Gay, et. al. (2009):

These strategies included prolonged participation at the site, persistent observation, peer debriefing, and collected documents (including film, articles, sliceof-life data, detailed descriptive data, especially through use of photography and note taking). It also involved developing an audit trail, practicing triangulation and practicing reflexivity. I will elaborate on a few of these strategies to clarify why they are outlined here.

The triangulation central to this study involved collecting data from several sources. Bailey (2007) suggests the importance of data collection "from respondents who occupy different social locations or are likely to have divergent views" (p. 77). In this study, the interviews involved three levels of groups whose involvement with the Seed to Supper program differed. For instance, I interviewed participants, instructors and community leaders. All of these interviewees were linked in some fashion to the Seed to Supper Program. The quantitative survey was 
another form of data collection that could be compared to the interview data and triangulated. Bailey (2007) recommends triangulating as many types of data as possible (p. 77). This study used as many options for triangulation as possible. Additionally, the long-term affiliation with the study and my involvement with the program established rapport and acceptance as an observer with key participants and community members. Lastly, the practice of reflexivity through journal keeping on a regular basis gave me the opportunity to go back through journals to recollect memories, observations and general discoveries. These proved helpful and informative, adding to the trustworthiness necessary for qualitative data collection.

Another factor influencing the validity of this study was serendipitous in nature, but very helpful and insightful to the analysis of the data. The numerous writing assignments during my course of study in the Leadership for Sustainability Education Masters program contributed to analysis and reflection of the work I was conducting for the study. I took every opportunity to reflect on this study for the course work, term papers and reflection writings required by my assignments.

\section{Limitations}

One limitation to consider in addressing the research design and the methods of this project is that it focused on multiple sites of one learning garden program-The Seed to Supper Program. With this in mind, generalization is limited by the small sample size of the study. The participants self-selected and generally had a predisposition for food literacy and gardening. 
For the purpose of the community partner, the information derived from the survey and interviews proved invaluable. For the researcher, the importance of impartiality and sample size point to the need for future evaluations, longitudinal studies and further opportunities to create a random population in which to measure the success of learning gardens and the impact on access to fresh locally grown food and community food security. The scope and scale of this project were limited by resources and time, and by the importance of serving the interests of a community partner.

In concluding this chapter on methodology, I want to describe my positionality in this research as a gardener and as a person who has wanted to understand food security, community food systems and access to locally grown foods throughout my life. My positionality has played a significant role in the research design and process.

\section{The Positionality of the Researcher}

The positionality of the researcher is an important contribution to the research process and is a pivotal aspect of any thesis project. My personal experience has played a significant role in my motivation about this research topic. My personal experience with food insecurity, as well as my desire to grow my own food to develop self-reliance has spanned five decades. I bring an understanding of the historical context described in chapter one concerning the deterioration of access to healthy local foods, and have also witnessed, and participated in, the beginnings of the local food movement. My family stayed in the urban 
neighborhoods of the 1960s and 1970s, and witnessed middle class flight, saw fruit stands disappear, along with the fresh bottles of milk delivered to our door replaced by plastic bottles of milk at a 7-11 convenience store on the corner next to the McDonald's restaurant $1 / 2$ block from our home.

As a young person my reaction to, and solution for, this abrupt change within my foodscape was to become a vegetarian. Influenced by the counterculture food movement and its resistance to the industrial food system, I felt empowered to plant one of my first gardens in the rocky soil of our urban backyard. My life-long quest to grow my own food began from a loss of choice and a lack of fresh locally-grown foods in my neighborhood. The garden as a place of learning has a personal significance in my life story.

The transformative powers of the learning garden directly changed my personal access to locally grown foods and empowered me by increasing my food literacy and attainment of garden-based knowledge. My first learning garden experience was in a public high school program in the early 1970s. We studied horticulture, plant identification, vegetable gardening and soil management. This learning garden experience proved transformative to my food literacy and knowledge base for growing my own food and overcoming some of the food barriers I faced in my life. The reason I chose to study learning gardens is directly linked to this early life educational/transformative experience. 


\section{Significance and Conclusion:}

The methods section describes how this research study was conducted and how the results were discovered. The Seed to Supper interviews and surveys and field data revealed a robust gardening community supported by many different community players and participants. As a gardener and a researcher, my willingness to get involved positioned me, and gave me the opportunity, to observe the potential of learning gardens and the various aspects of the Seed to Supper Program and the communities served. These components of the methodology are the nuts and bolts of the research process and position the researcher favorably (or not) into the community under examination. The next chapter focuses on the results of the study in relation to the research questions. 


\section{Chapter 4: Results}

\section{Learning Garden Scene 4: A Senior Center with a Focus on Fresh Locally-grown Foods}

Every day over 250 meals prepared for Riverside Court senior meals program use fresh locally grown foods from five community gardens, including Portland's city hall community garden. Serving meals prepared from fresh foods is one strategy Riverside Court uses to build a local sustainable community food system which increases access to locally grown foods. To strengthen these efforts, Riverside Court has partnered with the Seed to Supper program to improve food literacy for its members through hands-on gardening experiences. In my interviews at Riverside Court, members referred to increased self-reliance and improved food literacy as outcomes of their participation in the Seed to Supper program. This vibrant meal center is an example of a locally engaged community food system that has created a web of community gardens to serve its community, and sets the scene for the results discovered by this study.

\section{Introduction to Chapter 4}

This chapter addresses the four main research questions and presents the results and themes discovered through the data collection from the Seed to Supper sites. The first question addresses the impact on food insecure communities' access to fresh and local foods. The second research question examines the Seed to Supper program goals through place-based learning and learner empowerment. The third research question clarifies the barriers for the Seed to Supper participants and how 
they define these barriers and finally question four asks how the program increases food literacy, self-reliance and creates social capital.

\section{Overview to Research Question 1}

The first research question is: "How does the Seed to Supper program impact food insecure communities and their access to fresh and local foods?"

The data shows that the Seed to Supper program impacts food insecure communities by improving access to fresh and local foods through garden-based learning, which increases capacity for community building. The following three sections provide the findings from the survey, interviews and observations from the Seed to Supper research sites to support this general claim. Then, I show how community building fosters increased access to local foods through learning garden programs.

Survey Results: Increased Access to Fresh and Local Foods

The survey results showed that the Seed to Supper program has had a positive impact on food insecure communities and their access to fresh and local foods. First, survey results indicate that the workshops provided gardening knowledge that facilitated gardening practices (see Figure 3 Seed to Supper Survey Question 1). Second, Seed to Supper participants' indicated they were "encouraged to plant a garden" (see Figure 4 Seed to Supper Survey question 2). A majority of the participants also agreed they purchased more fruits and vegetables as result of the program and their gardening experiences (see Figure 5 Seed to Supper Survey Question 7). These results indicate that participation in the Seed to Supper program 
led to increased access to fresh and local foods. The following survey questions illustrate these findings:

Figure 3. Seed to Supper Survey Question 1

1. This workshop taught me something that I will be able to use in my garden.

\begin{tabular}{|c|l|c|c|c|}
\hline$\#$ & Answer & Response & $\%$ \\
\hline 1 & $1-$ disagree & 1 & $0 \%$ \\
2 & 2 - maybe & 15 & $7 \%$ \\
3 & 3 - agree & 188 & $92 \%$ \\
\hline & Total & 204 & $100 \%$ \\
\hline
\end{tabular}

Figure 4. Seed to Supper Survey Question 2

2. This workshop has encouraged me to plant a garden.

\begin{tabular}{|c|l|c|c|c|}
\hline$\#$ & Answer & Response & $\%$ \\
\hline 1 & $1-$ disagree & 5 & $2 \%$ \\
2 & 2 - maybe & 25 & $12 \%$ \\
3 & 3 - agree & 176 & $85 \%$ \\
\hline & Total & 206 & $100 \%$ \\
\hline
\end{tabular}

Figure 5. Seed to Supper Survey Question 7

7. I purchase more fresh fruits and vegetables.

\begin{tabular}{|c|l|l|c|c|}
\hline$\#$ & Answer & & Response & $\%$ \\
\hline 1 & $1-$ disagree & & 34 & $18 \%$ \\
\hline 3 & $2-$ maybe & & 39 & $21 \%$ \\
\hline & $3-$ agree & & 111 & $60 \%$ \\
\hline & Total & & 184 & $100 \%$ \\
\hline
\end{tabular}

These survey results indicate a positive impact for learners and support the conclusion that the Seed to Supper program improves participants' access to fresh 
and local foods. In addition, the interview responses added descriptive details and insights to the first research question.

Interview Responses: Increased Access to Fresh and Local Foods

The interview comments from the Seed to Supper participants confirmed the survey results (see Table 9 Comments from Seed to Supper participants). The results from the interviews to research question number one indicated that the majority of Seed to Supper interviewees (Group 1) gained enough experience to grow some their own fruits and vegetables. These responses indicated that the program imparted some knowledge the participants needed in order to increase their access to fresh and locally grown foods. The interviews also revealed the importance of building a supportive community where garden-based learning is encouraged and supported. The comments in Table 9 were generally in response to interview question 1, which asks: "As a result of taking a learning garden workshop, have your gained enough experience to grow some of your own fruits and vegetables?" However, since the interviews were semi-structured, often comments would come later in the interview in response to a different question. 
Table 9

Selected Comments from Seed to Supper participants related to research question 1

\begin{tabular}{|l|l|l|}
\hline Seed to Supper Participants & Site & Comment \\
\hline Bill & Brookplace & $\begin{array}{l}\text { "I had so many tomatoes and shared my tomatoes } \\
\text { with close friends. I don't buy many vegetables, } \\
\text { mainly fruits at a close by store. I concentrate on } \\
\text { [growing] tomatoes and green onions." }\end{array}$ \\
\hline David & $\begin{array}{l}\text { Riverside } \\
\text { This workshop... "what it has done for me is that I } \\
\text { am more selective about fruits and vegetables, I } \\
\text { go out of my way to eat more beets, swiss chard, } \\
\text { and broccoli, and I tell people all about my eating } \\
\text { habits... I grow my salad bowl on my balcony." }\end{array}$ \\
\hline Alicia & Bell Tower & $\begin{array}{l}\text { "I worked as a farm worker... and tried to grow } \\
\text { [on my own] potatoes and beans, but they didn't } \\
\text { grow, I didn't understand the needs of the soil, so } \\
\text { they didn't do so well." ... [From this workshop] "I } \\
\text { learned how to increase the fertility of the soil. So } \\
\text { I can grow a lot of vegetables in a small space and } \\
\text { continue year after year." }\end{array}$ \\
\hline Terry & $\begin{array}{l}\text { "One family took three containers to grow } \\
\text { tomatoes, basil and all the kids were trying new } \\
\text { foods. The Seed to Supper instructors did a really } \\
\text { good job-the Head Start families talked about } \\
\text { the class for weeks and we tied it into our } \\
\text { curriculum." }\end{array}$ \\
facility
\end{tabular}

These comments from Seed to Supper participants showed the positive impact from the program and how garden-based learning improved access to fresh and local foods.

Observations and Comments from Researcher Fieldwork Notes and Photos: Access to Fresh and Local Foods

In addition to the survey and interview results, my visits to the garden sites also provided further visual data illustrating the impact of the Seed to Supper program on the gardens. The garden beds were abundant with ripe tomatoes, onions, herbs and flowers in bloom. This visual data helped me understand the positive implications of the early survey results. This garden photo is evidence of how Seed to Supper garden-based learning impacted participants with their 
gardening skills thereby increasing access to local and fresh foods (see Figure 6 Abundant Garden Bed).

Figure 6. Abundant Garden Bed

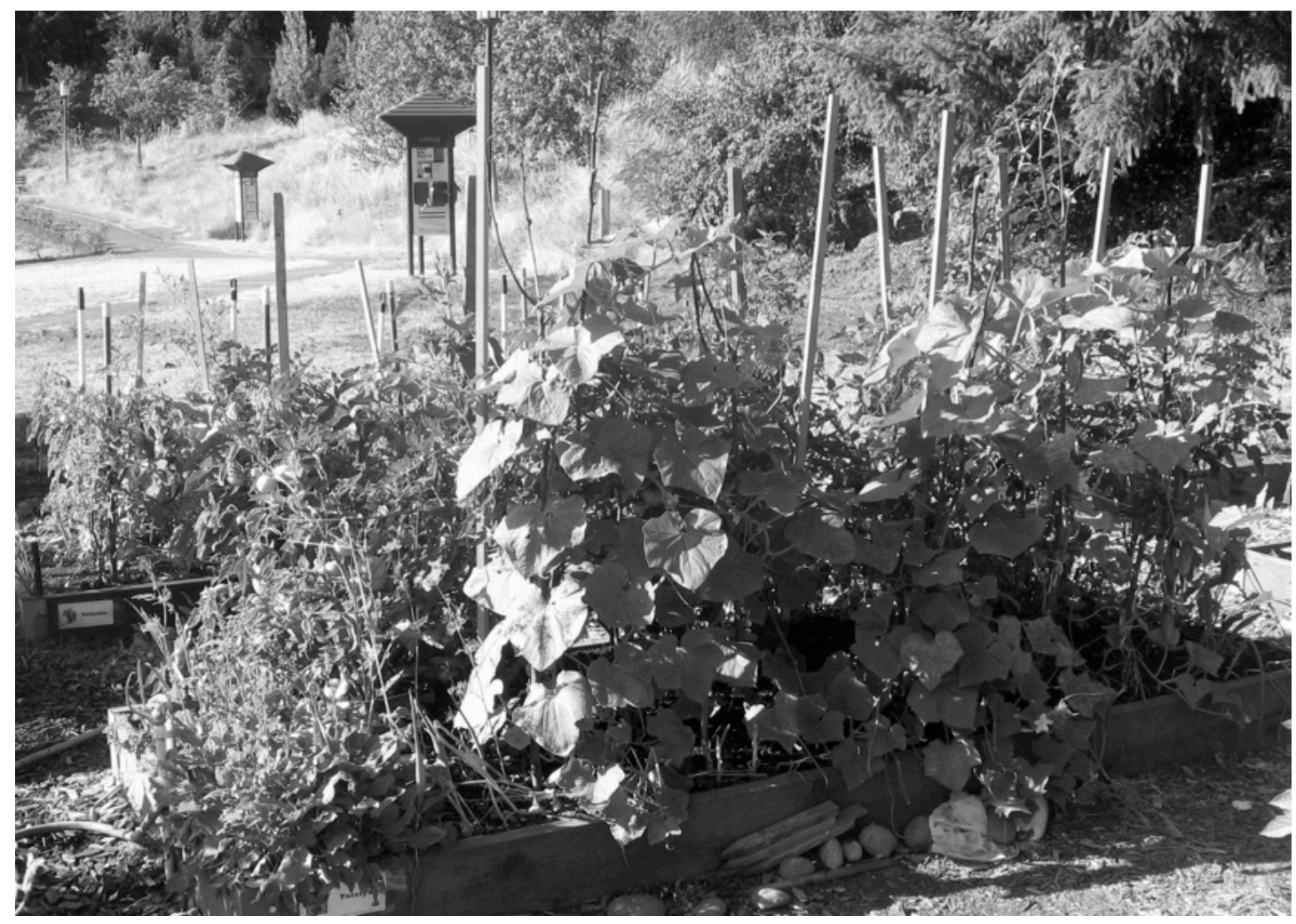

Community building emerged as a central theme as I examined the responses

that related to research question 1: "how does the Seed to Supper Program impact food insecure communities and their access to fresh and local foods?" This major theme points to the importance of building a supportive community where food literacy is encouraged and supported and where garden-based learning is allowed to take root-literally transforming community. The survey, interviews and fieldwork journals pointed to the importance of creating a place/community where members are encouraged grow food, share food and access food. Oregon Food 
Bank's Seed to Supper program is impacting food insecure communities by building community food security and, improving access to fresh and local foods through community building activities.

Community Building Leads to Greater Sense of Food Literacy and Access to Local and Fresh Food

The results of this study indicated that the Seed to Supper program impacts the communities it serves through community building, which fosters garden-based learning and food literacy. Community building and greater food literacy (to be discussed in more detail in research question 4) led to improved access to fresh and local foods in the Seed to Supper research sites. The results revealed through survey responses, participants' stories and observational data collected at the Seed to Supper sites supported the impact of the program. The stories from participants, as well as the abundant gardens, indicated that participants had greater access to local and fresh foods through increased community building activities. Moreover, the community building that resulted from the Seed to Supper classes helped members access more resources and activities that contributed to increased access to fresh and local foods.

For example, during each harvest season, the garden coordinator at Cascade View Food Pantry organizes a harvest fair and salsa-making contest. This annual event has grown into a celebration where sharing the harvest, recipes and gardening knowledge has led to increased community participation. The waiting list for the community garden keeps growing as a result of all these kinds of activities. All members of the food pantry community are welcome to attend this annual event 
that makes it very popular and well attended. Community building is found in the relationships built around the gardening activities and classes, including friendships and partnerships developed both internally and externally.

The following survey results also show enthusiasm for community-building activities and the eagerness of the participants to learn more about gardening.

Survey question 15, an open-ended question asked Seed to Supper participants to share a story about their gardening following their workshop experience (see Table 10 Survey Comments about classes). There were 111 responses to survey question 15 . These short stories speak to the impact on the relationships brought about by community building. All of the Seed to Supper survey respondents were anonymous.

Table 10

Selected Survey Comments about Classes Survey Question 15

\section{Please share a story about your gardening as a result of this workshop?}

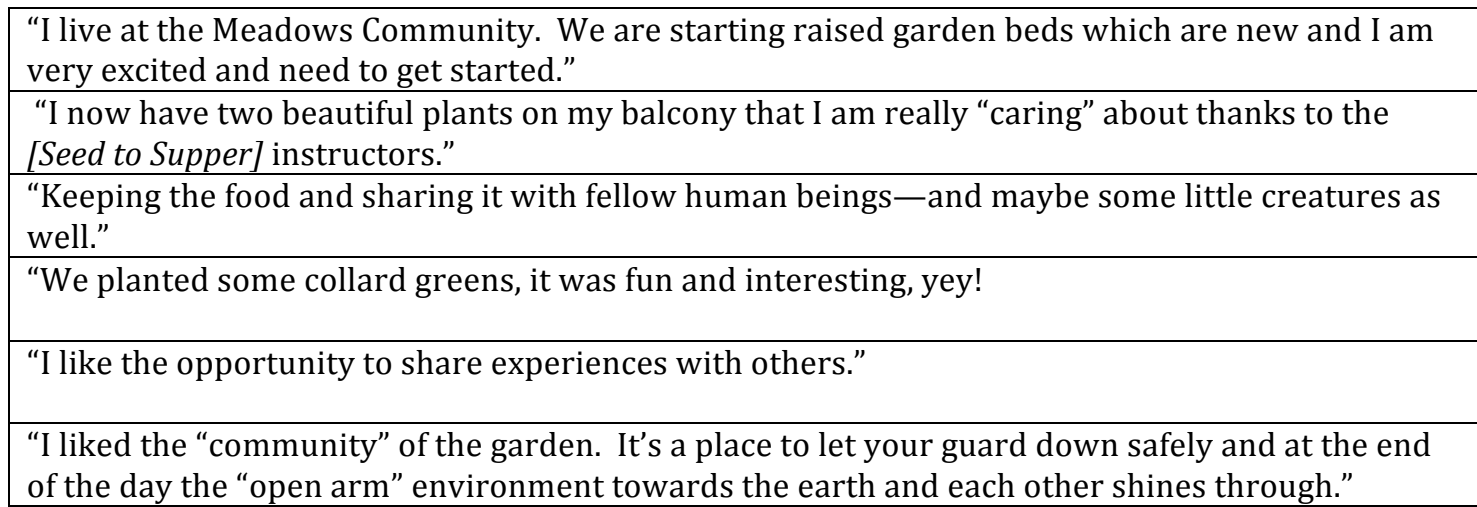

Many of these comments offer simple one-line responses, however, over $50 \%$ of the responses to this open-ended query related to some aspect of their 
relationships with others, and to their community, as well as the successes they were experiencing in the garden. For many of the participants, sharing stories about their gardening experiences were important to them, indicating they turned to their friends, family and neighbors to gain more information or advice about their garden pointing to the importance of community.

Three categories stood out among the 147 responses to Survey Question 17: "Where do you get your gardening questions answered?" The most common response was personal friend or family member and others; second, books, magazines, and brochures, and third, classes-most indicated the Seed to Supper class. I interpret these findings to indicate that learning from others combined with book knowledge and classes created a learning community for the participants. These informational communities offered participants answers about gardening practices, and also these communities provided support systems to build on each other's successes.

In addition to the survey results, the interviews with the Seed to Supper participants (Group 1) and with key community participants (Group 3) shared the importance of building a supportive community where food literacy is encouraged and supported and where there is a place to grow food, share food and access food. Seven out of nine interviewees agreed when asked: "Do you share what you grow with your relatives or neighbors?" Additionally, they shared that having access to garden-based learning close to home was valued, as was a supportive and sharing community environment. 
According to the participant interviewees, the Seed to Supper classes had encouraged them to plant a garden and thereby had increased their access to fresh and local foods. Additionally, they relied on their community's capacity for networking through internal and external partnerships that helped the participants access more garden-based learning, more resources, and basic skills to improve their food security and sense of community (see Table 11 Seed to Supper Interviewee comments about community). These comments are generally in response to the first seven questions of the Seed to Supper interview questions, see Appendix B for specific questions. The interviews were semi-structured and these comments were often at various points in the interview.

\section{Table 11}

\section{Selected Seed to Supper Interviewee comments about community}

\begin{tabular}{|l|l|l|}
\hline $\begin{array}{l}\text { Seed to Supper Participants } \\
\text { Group 1 }\end{array}$ & Site & Comment \\
\hline Louise & Brookplace & $\begin{array}{l}\text { "When you grow more than you can eat-they } \\
\text { have a table downstairs where you can put the } \\
\text { extras, we all seem to have tomatoes!... sharing is } \\
\text { number 1!..because there are so many folks } \\
\text { without a garden." }\end{array}$ \\
\hline Becky & Brookplace & $\begin{array}{l}\text { "I work at the food bank...that's where I get my } \\
\text { inspiration to share my knowledge with other } \\
\text { people, we get a lot of vegetables ... and I'm really } \\
\text { trying to implement them, and give others } \\
\text { different ways to serve them." }\end{array}$ \\
\hline David & $\begin{array}{l}\text { "This program, being here has made a big } \\
\text { difference in my life, given me a sense of } \\
\text { community and it's like I have a family and } \\
\text { everyone is a part of it....it's about community... } \\
\text { the quality and the life that we have... the meaning } \\
\text { is in the little things." }\end{array}$ \\
\hline
\end{tabular}

In addition to the Seed to Supper participants, several community members and leaders (Group 3) shared their opinions about learning gardens and community 
building with me (see Table 12 Community members and leaders, especially Group 3 Comments about value of community building). Braden, an instructor for a large garden educator program stated that "the goodwill that is fostered by learning garden programs is as important as the horticultural learning and these programs symbolize the importance of community building as possibly more important than the garden skills building." Similar to Braden's comments, other community leaders observed the importance of the sense of community that is fostered through potlucks, health fairs, workshops, collaborative programs and community gatherings focused on the community, as evidenced in Table 12. 
Table 12

Community members and leaders - Group 3 Comments about Value of Community Building

\begin{tabular}{|c|c|c|}
\hline $\begin{array}{l}\text { Community members and } \\
\text { leaders - Group } 3\end{array}$ & $\begin{array}{l}\text { Role in } \\
\text { Community }\end{array}$ & Comment \\
\hline Carol & $\begin{array}{l}\text { Elected } \\
\text { County } \\
\text { Official }\end{array}$ & $\begin{array}{l}\text { "This is really a priority of our district, to be } \\
\text { involved with the urban food movement and use } \\
\text { of the office and all the connections of the county } \\
\text { and the commissioners to help the community } \\
\text { outreach for more access to local food, more } \\
\text { knowledge for healthy food preparation and to } \\
\text { achieve that by working in partnership and } \\
\text { collaboration across jurisdictions... with multiple } \\
\text { agencies within the county. One of the foremost } \\
\text { agencies working on this is our health } \\
\text { department. We also have a sustainability } \\
\text { department and ... it fits with our image as a very } \\
\text { green community and the health departments' } \\
\text { health equity mission as well as the general } \\
\text { public health mission of creating community } \\
\text { where value is not just taking care of sickness, } \\
\text { but promoting healthy communities. } \\
\text { The other thing about gardening-- it's being } \\
\text { outdoors... and can be quite a public activity and } \\
\text { tends to sponsor relationships, so you meet your } \\
\text { neighbors...creating a greater community way... } \\
\text { [growing food] This is very much a foundation of } \\
\text { everybody's life - eating-it is also a great way to } \\
\text { cultural diversity." }\end{array}$ \\
\hline Misty & $\begin{array}{l}\text { Garden } \\
\text { Program } \\
\text { Coordinator }\end{array}$ & $\begin{array}{l}\text { "The gardens have provided greater access to } \\
\text { more fresh and local foods - in the middle of a } \\
\text { crime ridden area - the garden is viewed as a } \\
\text { sanctuary and a protected space - the community } \\
\text { in general honors this great space. Our } \\
\text { community garden is an oasis in a crime ridden, } \\
\text { gang and drug oriented neighborhood, the } \\
\text { garden time after time remains untouched by } \\
\text { vandalism, graffiti and I know this is considered a } \\
\text { sacred place in the community." }\end{array}$ \\
\hline
\end{tabular}

Misty, the garden program coordinator for Cascade View was amazed by the partnerships and friendships that the workshops promoted and how they provided a place for community building. Equally moved by the "sense of community" created by gardening, the Brookplace site coordinator, Helen feels that "gardening itself is a hopeful activity, it's a way for people to think of themselves in a different 
way and it's a place to hang out." In addition to the interviews, my observations reinforced the survey results and the interviewee responses about the importance of community building to accessing fresh and local foods.

I spent many hours at the Brookplace housing project over the three-year study period. The gardens expanded after the first year, and after many interviews at this location, I received invitations to attend community events. I enjoyed my visits and always came away feeling that this community had something special. I wanted this same feeling for my own neighborhood.

One of the most memorable events I attended was the Health fair at Brookplace (see page one, Learning Garden Scene 1). There were a dozen information tables next to the community garden beds and dozens more inside the community center. Many of the residents were sitting with friends eating turkey burgers from the community potluck and trying out the blueberry shakes. It was a pleasant day, hearing the stories and seeing all the residents relaxing and gathering information from all the service agencies. I felt a strong sense of place, as if I were at a farmer's market. The children were running around, the elders chatting and many experts were available to discuss health, nutrition, gardening, emergency food services and numerous ways to access skills and services to improve one's life. This scene is indelibly etched in my mind and stands out as one of the most powerful examples of sense of community. The Brookplace community has centered many of its activities around the community garden. 
Another site where I observed a strong sense of community was at Riverside Court with Seed to Supper participant, David's circle of friends. He spent a lot of time spreading the word about healthy eating and gardening and adding to the community by helping others help themselves. David mentored other gardeners, harvested produce and assisted the instructors for the Seed to Supper classes. The Seed to Supper provided resources for this community to build a learning environment that fostered a healthy sense of community.

This study shows that the Seed to Supper program impacts food insecure communities by providing greater access to garden-based learning, resources needed to help plant gardens, as well as community building activities. Activities such as community harvest tables, knowledge sharing and networking helped to increase access to fresh and local foods. When a food insecure community as a whole realized its potential to develop community food security, individuals and groups within that community began to use their abilities to garden, to teach others, and to lead. This capacity for increased community food security will be addressed in question four and in the concluding chapter.

\section{Overview to Research Question 2}

Research question two asks: "How are the goals of the Seed to Supper Program framed and presented to served communities?"

This research question addresses how the goals of the program are designed and operationalized within the context of the classes. The goals of the Seed to Supper Program are 1) community food security, 2) self-reliance and 3) building 
food security through improved nutrition. From my observations and interpretations of the data, the goals are framed and based on educational models that bring experiential learning/education to food insecure populations by helping them help themselves through self-reliance, improved nutrition and helping build community; many of the components of community food security. This study found that these goals were operationalized by the Seed to Supper program through placebased education and learner empowerment.

Place-based Learning and Learner Empowerment: Foundations of the Seed to

\section{Supper Program}

Place Based Learning

Experiential learning through hands-on instruction in a shared common space that is place-based is one of the foundations of the Seed to Supper program. Because the classes are place-based, the potential for shared traditions and culturally appropriate knowledge increased. The Seed to Supper program delivers this place-based garden learning approach in order to achieve its main goal of increasing community food security. This is achieved through greater understanding of our food systems, nutrition and ultimately self-reliance, within the context of each community. The place-based nature of the classes, which is unique at each of the sites, is a key element affecting how the goals are framed. The following survey results, interview responses and observations help analyze how the program in reaches its goals. 
In survey question 2: "This workshop has encouraged me to plant a garden" (see p. 3, Figure 4), 85\% of Seed to Supper participants felt encouraged to plant a garden. I found this result to reflect positively on the place-based success of the program. Each research site was unique and the program instructors adapted the curriculum to fit the learning environment. The positive result of survey question 2 , indicates this approach is working for the Seed to Supper program and helps to operationalize the goal to build greater community food security.

The next survey question that addresses operational strategies is survey question 14: "What would you recommend changing or adding to improve these workshops?" This question helps clarify how the program is framed because it provides insight into what participants are seeking to improve the program; what worked and what wasn't working within the place-based approach. Over $80 \%$ of the responses were positive. A few examples express this positive result: "the classes are great" and "nothing, they are just fine" and, "they were very helpful." The recommendations were unique to each site emphasizing the positive results of place-based approaches.

The interviews with the Seed to Supper instructors also clearly demonstrate how the Seed to Supper program is operationalized-these individuals make the program and curriculum adaptations to improve the program's effectiveness. Two of the three instructors interviewed for the study both served as Seed to Supper instructors at the sites where they worked, and also as program coordinators, providing services for Seed to Supper participants. Because of their unique 
positions, these instructors were best able to respond to the needs of each site.

Table 13 shows comments from all of the instructors in response to interview

question two: "In your opinion how effective is the Seed to Supper in accomplishing

its goals?"

Table 13

Responses from Seed to Supper Instructors on the Effectiveness of Program

\begin{tabular}{|c|c|c|}
\hline $\begin{array}{l}\text { Seed to Supper } \\
\text { Instructors - Group } 2\end{array}$ & Site & $\begin{array}{l}\text { Comments to question: In your opinion how } \\
\text { effective is the S2S in accomplishing its goals? }\end{array}$ \\
\hline Susan & $\begin{array}{l}\text { Bell Tower } \\
\text { Title: } \\
\text { Services } \\
\text { Coordinator }\end{array}$ & $\begin{array}{l}\text { "It is a successful class if it can inspire someone... } \\
\text { even if it is to plant a small container garden } \\
\text { because a lot of people don't have a lot of space, so } \\
\text { that is really good, because it [the program] is } \\
\text { geared towards whatever space you do have." }\end{array}$ \\
\hline Raymond & $\begin{array}{l}\text { Riverside } \\
\text { Court } \\
\text { Title: } \\
\text { Services } \\
\text { Coordinator }\end{array}$ & $\begin{array}{l}\text { "The Seed to Supper program is helping families in } \\
\text { a variety of ways, from the basic elements... it } \\
\text { demystifies the whole idea of having a community } \\
\text { garden and of gardening itself and it reawakens } \\
\text { for many people the process they were used to as } \\
\text { children...here at Riverside we are getting away } \\
\text { from processed foods to natural foods... we are } \\
\text { distributing (these foods) to those people most in } \\
\text { need. And we took it upon ourselves here at } \\
\text { Riverside to try to focus a lot of these people's } \\
\text { energy. The way we thought to begin this was } \\
\text { with the Seed to Supper Program. We had a five } \\
\text { week class in which people learn what farming is } \\
\text { and through that, the process of food became } \\
\text { demystified." }\end{array}$ \\
\hline Linda & $\begin{array}{l}\text { Lakeview } \\
\text { Correctional } \\
\text { Facility } \\
\text { Volunteer } \\
\text { Seed to } \\
\text { Supper } \\
\text { Instructor }\end{array}$ & $\begin{array}{l}\text { "Since re-introducing the garden in our facility, we } \\
\text { have struggled with getting the kitchen to use the } \\
\text { produce [from the garden]...because they were } \\
\text { used to the easy, open a box, everything is washed } \\
\text { and throw it on a plate and through the Seed to } \\
\text { Supper program, it was really instrumental in- } \\
\text { the women-asking for the food that was being } \\
\text { grown in the garden and wanting that as part of } \\
\text { their meals and also some of them worked in the } \\
\text { kitchen...they helped promote that. I think the } \\
\text { awareness and the learning about organic } \\
\text { foods...through tasting the food [from the garden] } \\
\text { and talking about the difference, all of this led to } \\
\text { the expansion of the garden ...and a lot of this has } \\
\text { come from the women asking for the food from } \\
\text { the garden." }\end{array}$ \\
\hline
\end{tabular}


The responses from the Seed to Supper instructor about the effectiveness of the program put into perspective the impact the program had on participants within the place they resided or frequented. As pointed out in the comments, participants often gained valuable knowledge from the program and in many instances this knowledge impacted their diets through the inclusion of locally grown foods into their diets. Each is example exemplifies the unique responses to place, learner's needs and available resources.

Raymond, a Seed to Supper instructor and site coordinator facilitated placebased learning by relying on place-based experiential learning in the context of the community he served. His approach to learning involves creating relationship to working the land and making connections between working the soil, farming and consuming locally grown foods. Making these connections triggered memories of farming as children or, for some, as young adults. He stated, "for centuries, people have farmed the Willamette Valley - farming starts with a seed and our hands in the soil, there is no great mystery." These instructors adapted the Seed to Supper program to fit the needs of the participants using place-based education and also meeting the goals of the program.

During the interview with Terry, a Seed to Supper Participant and Head Start instructor, she shared the importance of tying the Seed to Supper curriculum into her classroom unit on growing food. By connecting the children and their families on site to participate in a container gardening workshop for apartment dwellers she felt the program met their curriculum goals to teach about food literacy. 
Additionally, the Seed to Supper program goals of community food security, selfreliance and improving nutrition were met by this collaborative place-based approach. The Seed to Supper program provided all the resources needed to plant seedlings in five-gallon containers, including fertilizer to stimulate plant growth. This insured success for the gardeners contributing to increased understanding of growing one's own food in the context of where one resides. Table 14 provides additional comments about the benefits of place-based education from community members and leaders (Group 3).

Table 14

Comments from Community Members on Place-based Learning

\begin{tabular}{|c|c|c|}
\hline $\begin{array}{l}\text { Community members and } \\
\text { leaders - Group } 3\end{array}$ & $\begin{array}{l}\text { Role in } \\
\text { Community }\end{array}$ & Comment \\
\hline Helen & $\begin{array}{l}\text { Brookplace } \\
\text { Services } \\
\text { Coordinator }\end{array}$ & $\begin{array}{l}\text { "The community garden is a place to hang out } \\
\text { and creates a sense of community and can be a } \\
\text { positive thing... working together on flower beds, } \\
\text { all the interactions are so important." } \\
\text { In my position-- to facilitate services, one of the } \\
\text { things that has really helped me with this garden } \\
\text { in terms of the work I do...is really getting to } \\
\text { know people, in the process of working in the } \\
\text { garden, doing the work, you get to hear about } \\
\text { their goals and hear about who they are.. it is a } \\
\text { place to hang out." } \\
\text { With the Seed to Supper...it is dependent on the } \\
\text { instructor and their connection to the } \\
\text { participants, it is very important." }\end{array}$ \\
\hline Misty & $\begin{array}{l}\text { Cascade View } \\
\text { Garden } \\
\text { Program } \\
\text { Coordinator }\end{array}$ & $\begin{array}{l}\text { "Cascade View's community garden is a place } \\
\text { where participants can develop pride, } \\
\text { independence and hope. Through celebration of } \\
\text { place, Seed to Supper classes and bringing in } \\
\text { speakers about specific topics of interest to our } \\
\text { community members. Over } 100 \text { people attend } \\
\text { our annual garden party. We sponsor a salsa- } \\
\text { making contest and invite all of the community to } \\
\text { attend the harvest party." }\end{array}$ \\
\hline
\end{tabular}


Each of these community members organized Seed to Supper classes or workshops enabling them to see first hand the impact of the program on participants and their communities. Each community is fostered by a place-based learning approach where members are encouraged to participate based on their needs.

One example of place-based learning that illustrates this approach took place at Lakeview Correctional Facility. To accommodate the incarcerated Seed to Supper participants, the program instructors adapted the garden planning lesson so that learners could implement their plans once they were released from the correctional facility. According to the Seed to Supper instructor, many of these garden plans have been put into use by several of the participants (now released). Additionally, several of the participants have been trained to help instruct the Seed to Supper classes at the correctional site (there is an extensive learning garden at this facility as well). Many of the surveys from this site reflected the gardening planning and the participants' anticipation to garden in the future and also their willingness to help others learn to garden.

As I became more familiar with the sites, I found that the place-based application of the Seed to Supper curriculum was critical in meeting the needs of Seed to Supper community site members. I saw Seed to Supper participants sharing knowledge with one another. Sharing knowledge about what to plant and when to plant created place-based support systems that advanced learner empowerment and self-reliance-program goals for the Seed to Supper program. 
Often the gardeners with advanced garden knowledge didn't speak a common language with other community members. At Brookplace, funding for the language interpreter during the Seed to Supper classes was eliminated, which hindered communication between community members and with the Seed to Supper instructors. The following photos, Figures 7 and 8 illustrate the importance of place-based communication in a community garden.

Figure 7. Photo of Garden Signage I

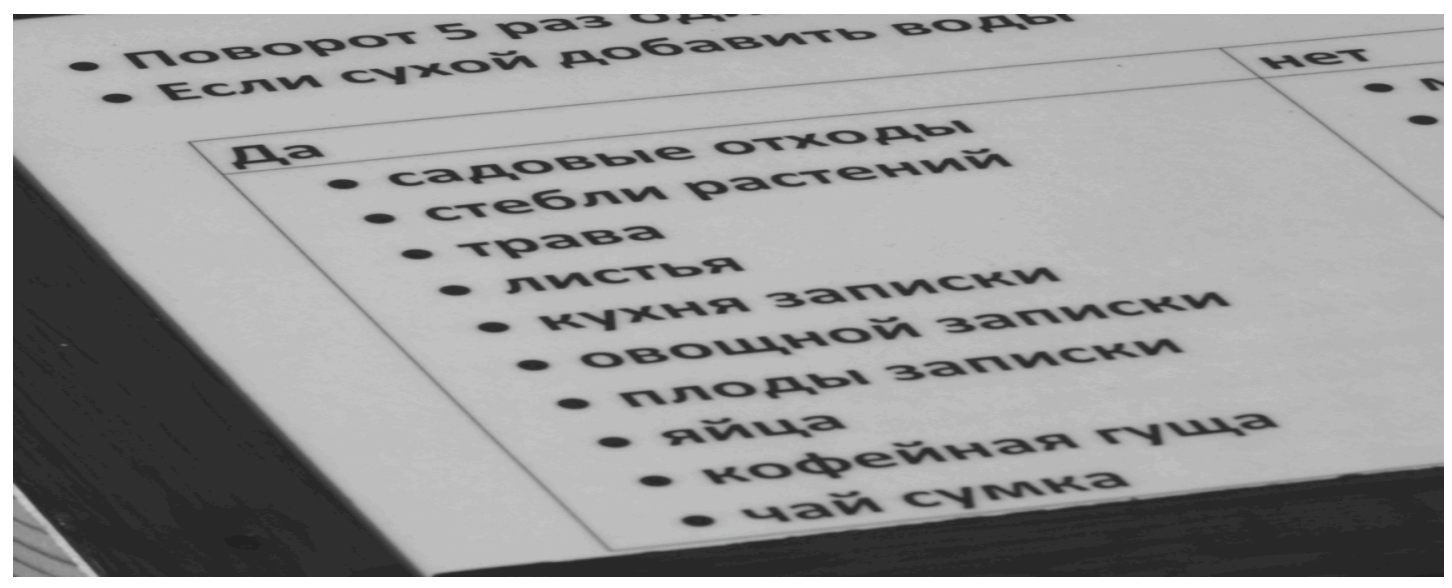

This signage in Russian sits alongside another sign in English, both list appropriate foods and items for a composting system installed at Brookplace during the Summer 2011 by a Portland State University Senior Capstone course. This place-based learning experience stressed the importance of accommodating language needs. 
Figure 8. Photo of Signage II

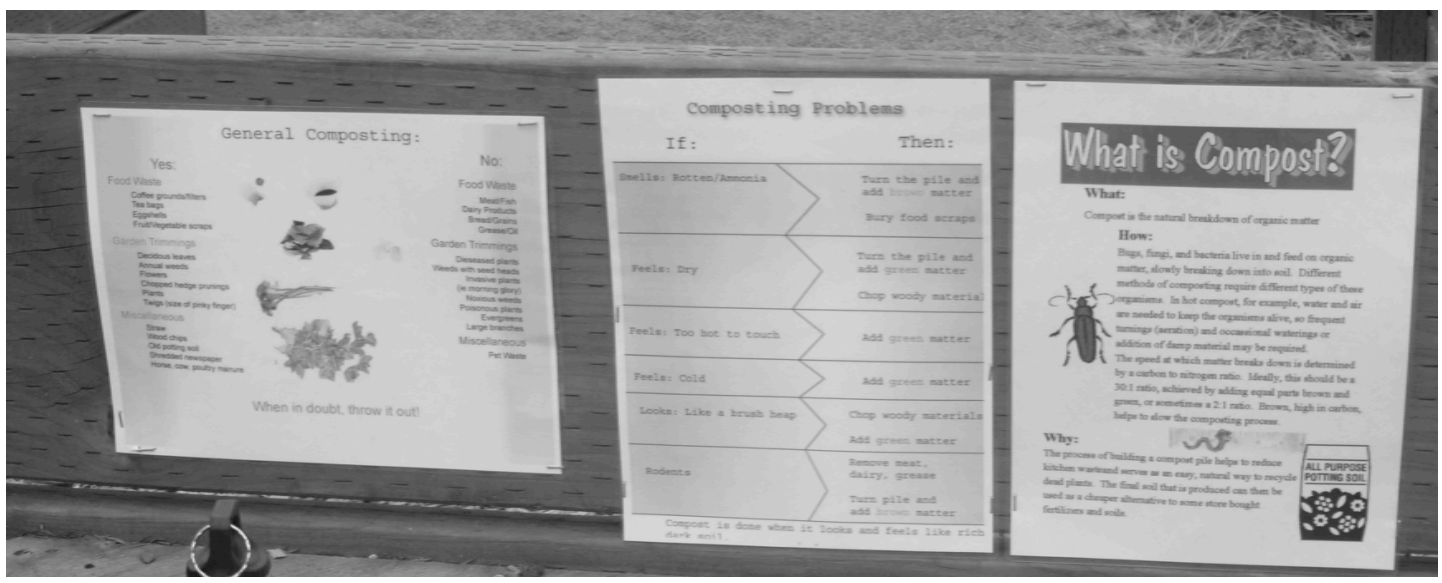

The signage installed at Forest Hills shows gardeners how to compost and what to expect. One community needed language accommodation and the other needed basic information on how to compost. Both examples show a place-based response to the learner's needs about composting specific to the community they live in.

Learner Empowerment: Building on Success

In addition to pointing out the importance of a place-based approach, the survey and interview responses indicated that participants had become empowered through their participation in the Seed to Supper program. Learner empowerment led to greater community food security by augmenting self-reliance, increased community involvement and improved gardening skills. The following results indicate that in addition to place-based learning, the Seed to Supper program has positive impacts on learner empowerment.

The survey results indicated that Seed to Supper participants' interest and knowledge increased, thereby helping the to improve their gardening techniques and enhancing their sense of empowerment. Survey question 15: "Please share a 
story about your gardening as a result of this workshop?" best illustrates learner

empowerment and how that impacts Seed to Supper participants, see Figure 9.

Figure 9. Survey comments about Learner Empowerment

\section{Please share a story about your gardening as a result of this workshop?}

\begin{tabular}{|l|}
\hline $\begin{array}{l}\text { "I have gained a great deal of valuable knowledge which will assist me in becoming a successful } \\
\text { gardener." }\end{array}$ \\
\hline "We're planting more this year!" \\
\hline "I started seedlings from seed for my garden for the first time in my life." \\
\hline "I am planning to re-think how I plant and raise tomatoes." \\
\hline "My plants are growing now because I took this class and now I know what I did wrong." \\
\hline "I have learned how to keep bugs away, how to trellis and many other things." \\
\hline "I've planted marigold and used the lime for my tomatoes, I also put a few trellises in. My garden \\
is growing perfect." \\
\hline "I am going to try to start my own herb garden." \\
\hline "I have created a garden idea and made the idea achievable." \\
\hline "My plan is to build a garden, involve my daughter in our garden. I also want to participant in \\
"plant a row"-that is so good! Then, 3 days a week --take my daughter to volunteer at a \\
community garden and give her the gift of giving."
\end{tabular}

Many of these comments reflect a willingness to try new garden techniques, which led to greater self-confidence in the gardens. Increasing garden knowledge had a significant impact on Seed to Supper participants and their access to locally grown foods and their sense of empowerment.

The interviews with the following Seed to Supper participants revealed a sense of achievement and learner empowerment. Both of these participants felt they had gained knowledge, and additionally they felt empowered to help other people in their communities access more knowledge about gardening and preparing food from fresh grown foods as indicated in Table 15. 
Table 15

Selected Comments from Seed to Supper participants on Learner Empowerment

\begin{tabular}{|c|c|c|}
\hline $\begin{array}{l}\text { Seed to Supper Participants } \\
\text { Group } 1\end{array}$ & Site & Comment \\
\hline David & $\begin{array}{l}\text { Riverside } \\
\text { Court }\end{array}$ & $\begin{array}{l}\text { "The advantages [of growing your own food] } \\
\text { there are so many, for one, the satisfaction of } \\
\text { putting the time and effort, plus, you know what it } \\
\text { does for older people, it is gives you something to } \\
\text { look forward to. Life is so much more, if you have } \\
\text { something to look forward to... also it is } \\
\text { comforting, and when you're growing and } \\
\text { planting you have to plan how to water them, } \\
\text { what you're going to do with them and it also } \\
\text { works with the rest of your life." } \\
\text { The first thing they [Seed to Supper instructors] } \\
\text { did, (to encourage me) ... was to show me the } \\
\text { results of gardening and healthy food, and, it's not } \\
\text { just feeding me - the garden is for the community } \\
\text {... Plus, you're learning... people come to me about } \\
\text { their gardening questions and what I do is } \\
\text { volunteer } 7 \text { days a week for Loaves and Fishes. }\end{array}$ \\
\hline Becky & Brookplace & $\begin{array}{l}\text { "I do buy a lot more vegetables even in the } \\
\text { winter, now than I did before. I had never grown } \\
\text { zuchinni or squashes and you know I didn't really } \\
\text { know what to do with them. Now, I'm teaching } \\
\text { "Healthy cooking on a Budget" here. ...A lot of } \\
\text { people don't know what to do with a lot of } \\
\text { vegetables and I started a class to teach them how } \\
\text { to work with the fruit and then we got the } \\
\text { gardens, a lot of people enjoy growing but they get } \\
\text { tired of eating it the same way." }\end{array}$ \\
\hline
\end{tabular}

As these interview comments point out, learner empowerment often led to greater

community involvement, leadership roles, and the communities were able to

address food security through the human resources available on site.

The following Table 16 shows that community members and leaders also

commented on the importance of learner empowerment as important for

community food security. In framing the Seed to Supper classes, it was important to

these leaders for participants to see the benefits of growing their own foods and of 
empowering others to have the confidence to garden. Each of these community

members views learner empowerment from a different perspective, but they all

value the impact garden-based learning has on food insecure populations.

Table 16

Comments from Community Members and Leaders about Learner Empowerment

\begin{tabular}{|c|c|c|}
\hline $\begin{array}{l}\text { Community members and } \\
\text { leaders - Group } 3\end{array}$ & $\begin{array}{l}\text { Role in } \\
\text { Community }\end{array}$ & Comment \\
\hline Misty & $\begin{array}{l}\text { Cascade View: } \\
\text { Garden } \\
\text { Coordinator }\end{array}$ & $\begin{array}{l}\text { "The classes and gardens increase self-sufficiency } \\
\text { and enhance their experience in the garden... } \\
\text { they grow their own food. Cascade View has } \\
\text { been successful in achieving the goals of the } \\
\text { program, and the director of the facility wanted } \\
\text { to create more space for the garden program... to } \\
\text { give people a chance to develop pride, } \\
\text { independence and hope." }\end{array}$ \\
\hline Helen & $\begin{array}{l}\text { Brookplace } \\
\text { Services } \\
\text { Coordinator }\end{array}$ & $\begin{array}{l}\text { "Gardening is such a complex skill, you need to } \\
\text { know how to plant, prepare your soil, you have to } \\
\text { learn how to incorporate gardening into your } \\
\text { life... as a lifestyle... gardening is not something } \\
\text { you can be successful at without some basic } \\
\text { garden knowledge. ... there is canning, and what } \\
\text { to do with all the produce you get, how to use } \\
\text { what you grow to provide food during the winter. } \\
\text { You grow different things in each month of the } \\
\text { year. The educational component is key to access } \\
\text { to garden knowledge. And to help shift the } \\
\text { cultural perspective of gleaning excess foods } \\
\text { from corporate food systems to growing your } \\
\text { own." }\end{array}$ \\
\hline Melissa & $\begin{array}{l}\text { Community } \\
\text { Gardens } \\
\text { Director } \\
\text { (Metro } \\
\text { region) }\end{array}$ & $\begin{array}{l}\text { [referring to Cascade View gardens] "it is a } \\
\text { fabulous concept and gardens are really a } \\
\text { beautiful thing... you walk by and can feel that- } \\
\text { it's pretty contagious. They provide options and } \\
\text { feelings of empowerment by providing pathways } \\
\text { for growing your own food. There are many } \\
\text { benefits... gardening with other people, the value } \\
\text { in social activities and building leadership and } \\
\text { self-sufficiency for people... especially the } \\
\text { connectedness to others." }\end{array}$ \\
\hline
\end{tabular}


Each community member had a different set of criteria that described how learning garden programs contributed to learner empowerment and how this helps build sense of self within the community.

One example of the impact of learner empowerment took place during a Seed to Supper class I was assisting. During this class, it became clear to us (the instructors) that the participants wanted to lead the discussion and share their gardening stories about planting seedlings. They were refining their gardening expertise through comparing notes and sharing stories and knowledge. There was a quiet pause as the instructors let go of the planned slide show and let the class proceed-self-led by the participants themselves. In my observation, these kinds of open discussions helped the participants practice their knowledge and share what they had learned about garden-based knowledge through their experiences (Research Journal, Spring, 2011). In all of my interactions with Seed to Supper participants I gained additional garden knowledge in the form of advice, food preparation for garden vegetables and cultural knowledge.

One afternoon while visiting Brookplace for an interview and photo session with several gardeners, a well-known gardener explained how to make green Borscht using sorrel leaves from her garden. The interesting aspect of this encounter was that she did not speak English and I did not understand Russian, with the help of other people visiting the garden that day, I left with a thorough understanding of how to make her sorrel soup. I had hoped to interview her, but was never able to connect with an interpreter to do so. By sharing her recipe with 
me, and the visitors in the garden that day, she felt empowered by the exchange. The encounters I had with her proved to be productive exchanges, which contributed to my observations of the garden culture at Brookplace. The learning garden is an ideal location for impromptu learning settings, which empower learners-especially learner's with previous experience.

The data shows that the Seed to Supper gardening classes are framed to help participants build greater connections to each other through place-based, garden learning. And, when individuals are empowered to apply what they have learned-this led to greater sharing and success in the gardens and communities. On the whole, the Seed to Supper participants' felt they had learned enough through the garden workshops and felt encouraged to grow more fruits and vegetables thereby successfully achieving the program goals.

\section{Overview to Research Question 3}

Research question three asks: "Do these goals accomplish the overarching need for increased food security in urban and peri-urban Portland?"

The Seed to Supper program goals include increasing community food security, increasing self-reliance and improving nutrition to increase food security. However, the barriers to increased food security remain daunting for food insecure populations. While this research shows the Seed to Supper program does increase food security, the analysis of this research question focuses on the barriers to food security indentified in the findings of the survey data and interview responses. The relationship between increasing food security and the barriers directly correlate to 
whether or not the program is successful in achieving its goals. The barriers that emerged include: cost and availability of fresh fruits and vegetables, access to garden space, transportation, and economic hardship.

\section{Barriers to Food Security}

Cost and Availability of Fruits and Vegetables

The majority of the survey respondents and interviewees agreed that cost is a major consideration when purchasing fruits and vegetables (see Figures $10 \& 11$ ). Survey question 13: "What prevents you from obtaining fresh fruits and vegetables or growing your own?"-provides a framework for a more detailed exploration of the barriers to food security. This question specifically asked participants about barriers to obtaining or growing their own food. Fifty eight percent listed cost, 52\% listed garden space, $35 \%$ listed availability and $21 \%$ listed no time to garden. Figure 10 shows the results to question 13 , the barriers to obtaining fruits and vegetables. 
Figure 10. Barriers to Obtaining Fruits and Vegetables or Growing Your Own.

13. What prevents you from obtaining fresh fruits and vegetables or growing your own? Check all that apply

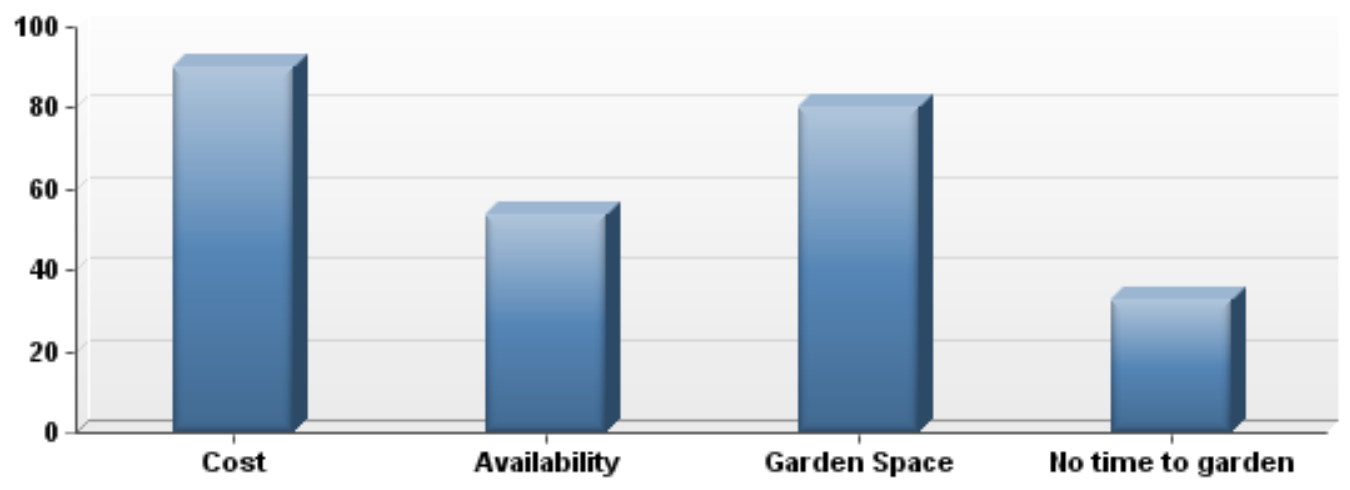

Min Value

Cost and space consistently stand out as the biggest barriers to food security.

The survey results from question 12: "What additional things do you need to grow a garden?" identified seeds and money to buy garden supplies as most needed, third was space to garden, followed by garden tools and advice, see Figure 11. 
Figure 11. Survey Results for Additional Items Needed to Grow a Garden.

\section{What additional things do you need to grow a garden? Check all that apply.}

\begin{tabular}{|c|c|c|c|}
\hline \# & Answer & Response & $\%$ \\
\hline 1 & Seeds & 124 & $66 \%$ \\
\hline 2 & Garden Advice & 74 & $40 \%$ \\
\hline 3 & Labor in Garden & 53 & $28 \%$ \\
\hline 4 & $\begin{array}{l}\text { Access to how-to } \\
\text { Garden Books }\end{array}$ & 58 & $31 \%$ \\
\hline 5 & Garden Space & 80 & $43 \%$ \\
\hline 6 & $\begin{array}{l}\text { Help putting in } \\
\text { garden }\end{array}$ & 41 & $22 \%$ \\
\hline 7 & Gardening tools & 78 & $42 \%$ \\
\hline 8 & $\begin{array}{l}\text { Money to buy } \\
\text { garden supplies }\end{array}$ & 98 & $52 \%$ \\
\hline 9 & Other & 31 & $17 \%$ \\
\hline
\end{tabular}

As indicated above in Figures 10 \& 11, Seed to Supper participants felt that cost is the single biggest barrier to obtaining fresh fruits and vegetables or growing them.

Although cost consistently impeded access to fresh grown foods, the importance of including fruits and vegetables was shown to be an important dietary priority for Seed to Supper participants. The following survey question asked participants how often they eat fruits and vegetables. 
Figure 12. Frequency of Consumption of Fruits and Vegetables

11. How often to you eat fresh fruits and vegetables?

\begin{tabular}{|c|l|l|c|c|}
\hline$\#$ & Answer & Response & $\%$ \\
\hline 1 & 1 time per day & & 70 & $35 \%$ \\
2 & $2-3$ times a day & & 79 & $39 \%$ \\
3 & Once a Week & 17 & $8 \%$ \\
4 & 5 times a Week & & 36 & $18 \%$ \\
\hline & Total & 202 & $100 \%$ \\
\hline
\end{tabular}

$\mathrm{N}=202$

This survey result indicates a potential correlation between participation in the Seed to Supper program and the increased consumption of fruits and vegetables.

However, this claim would require a further longitudinal study for validity.

The interview responses further support these results and provide insight into how cost impacts shopping patterns, including how Seed to Supper interviewees decide what to purchase and why, and what influences overall consumption of fruits and vegetables. During an interview with the Seed to Supper instructor at Bell Tower, she explained how people often have to make difficult and careful choices when using their limited amount of food stamps (SNAP) to purchase foods, especially fresh fruits and vegetables.

The responses to interview question six focus on Seed to Supper participants' responses to the question: "what influences your decision to buy fruits and vegetables?" When participants were asked in the interview what influences their decision to buy fruits and vegetables, cost was the number one factor, see Table 17. This was consistent with survey results, which showed $58 \%$ of the respondents checked cost as a factor in obtaining fruits and vegetables (see Figure 10). The 
second factor that interviewees said influenced their positive decision to buy fruits and vegetables was nutritional value as evidenced in Table 17. Sixty percent of the survey respondents agreed that they purchase more fruits and vegetables at the end of a Seed to Supper workshop (this result also supports the need for further study as indicated for Figure 12 results.)

Additionally, when asked during the interview if they felt they ate enough fruits and vegetables, one half of the interviewees said they do not eat enough fruits and vegetables. When they discussed their shopping habits and decisions about fruits and vegetables, cost was the biggest barrier to eating more fruits and vegetables.

Table 17

Aspects that Influence Purchase of Fruits and Vegetables

\begin{tabular}{|c|c|c|}
\hline \multicolumn{3}{|c|}{$\begin{array}{l}\text { Interview question } 6 \\
\text { What influences your decision to buy fruits and vegetables? }\end{array}$} \\
\hline Most important Influences & & Least mentioned influences \\
\hline Cost -6 & Availability -2 & Taste -1 \\
\hline Nutritional Value - 5 & Transportation - 2 & Other - 0 \\
\hline
\end{tabular}

Several Seed to Supper participants shared stories about the cost of fruits and vegetables, (see Table 18). The importance of and the nutritional value of fruit and vegetables are highlighted by the following comments. Consistent with the preceding results, the barriers of cost, availability, and transportation are found these comments. 
Table 18

The Impact of Cost and the Importance of Fresh Fruits and Vegetables.

\begin{tabular}{|c|c|c|}
\hline $\begin{array}{l}\text { Seed to Supper Participants } \\
\text { Group } 1\end{array}$ & Site & General Comments (from interviews) \\
\hline Louise & Brookplace & $\begin{array}{l}\text { "I'd like to grow some fruit... or pick my own...I am } \\
\text { a big fruit eater and it is expensive therefore that } \\
\text { is one of the things I would really like to have in } \\
\text { my garden... I would eat more of the food that I } \\
\text { like, meaning the fresh vegetables, fruits are still } \\
\text { at a premium, I actually have to buy less produce } \\
\text { because of the money involved." }\end{array}$ \\
\hline David & $\begin{array}{l}\text { Riverside } \\
\text { Court }\end{array}$ & $\begin{array}{l}\text { "I'll get Brussels sprouts, which I like and } \\
\text { normally they are } \$ 4-5 \text { per pound, but the } \\
\text { Christmas before last...you could get } 2 \text { to } 3 \\
\text { pounds of Brussels Sprouts for } \$ 1.99 \text {, boy, that's a } \\
\text { deal... I do go to the farmer's market, but they are } \\
\text { a little over-priced. I like going there and looking } \\
\text { around, but I'm on a very limited budget." }\end{array}$ \\
\hline Alicia & Bell Tower & $\begin{array}{l}\text { "I have always known it is healthy to eat fruit and } \\
\text { vegetables - as much as you can. But recently, I } \\
\text { have thought more about it because my son has } \\
\text { health issues. I am trying and I realize how } \\
\text { important it is to eat a healthy diet...we shop at } \\
\text { WinCo, Food for Less... the biggest influences on } \\
\text { my decisions to buy fruits and vegetables is } \\
\text { nutritional value and cost. I am looking for the } \\
\text { cheapest, but healthiest (fruits and vegetables)." }\end{array}$ \\
\hline Mary & Brookplace & $\begin{array}{l}\text { "I'm trying to get more fruits and vegetables into } \\
\text { my diet, nutritional value is important. [I grow } \\
\text { fruits and vegetables] because they are cheaper, } \\
\text { and they taste better." }\end{array}$ \\
\hline $\begin{array}{l}\text { Misty-Seed to Supper Instructor } \\
\text { and Service Coordinator }\end{array}$ & Cascade View & $\begin{array}{l}\text { "One woman participating in this garden told me } \\
\text { "...because of this garden is why we have fresh } \\
\text { foods"... cost is big factor and her children like } \\
\text { vegetables now- because of the garden." }\end{array}$ \\
\hline
\end{tabular}

Although cost is a consideration, the majority of interviewees value fruits and vegetables and 39\% eat fruits and vegetables 3 times a day (see Figure 12). This indicates the importance of including fruits and vegetables in their diets, in spite of the cost. Many of the comments in Table 17 support this major barrier, however, the desire to access more fruits and vegetables is indicated as well. 


\section{Access to Garden Space}

Access to garden space ranked second to cost as a barrier to accessing fresh fruits and vegetables (see Figure $10 \& 11$ ). For the Seed to Supper participants, access to garden space is a major barrier. In survey question eight, "I currently use a community garden space," $46 \%$ of the respondents indicated they did not use a community garden space. In the next survey question nine, "I have a garden in my yard," $37 \%$ of the respondents did not have a garden in their yard, while $48 \%$ did have a garden in their yard. Approximately half of the respondents have access to a garden space, which is important, since a place to grow food is critical to building community food systems. These results are further elaborated on in the interview responses related to access to garden space.

Seed to Supper participants emphasized the importance of access to garden space close to home. If interviewees did not have garden space they all maintained container gardens. To overcome this barrier, the site coordinator at Bell Tower (Learning Garden Scene 3) organized container gardening classes to interested members of the community. The Seed to Supper program provided all the containers, soil, fertilizers, seeds and plants to participants. Several participants were delighted to have everything available and in their hands so they could more fully understand how to grow lettuce on their balcony or doorstep.

The container gardening classes are popular and well attended according to Seed to Supper instructors and community leaders. The following Table 19 highlights comments from the participant interviews related to container gardening 
and the need for more space to garden in. Although this barrier inhibits access to

locally grown fruits and vegetables for Seed to Supper participants, the container

gardening workshops provide a limited increase in access to both space to garden

access to fruits and vegetables.

Table 19

Comments about Container Gardening and Comments About Access to Garden Space

\begin{tabular}{|c|c|c|}
\hline $\begin{array}{l}\text { Seed to Supper Participants } \\
\text { Groups } 1,2 \& 3\end{array}$ & Site & Comment \\
\hline Alicia & Bell Tower & $\begin{array}{l}\text { "I have a small space, but I have plants in buckets, } \\
\text { zuchinni, tomatoes, but I want to improve the soil. } \\
\text { I also have a garden here at Bell Tower...we need } \\
\text { more help, if the agencies could help develop } \\
\text { more garden space, seeds, soil amendments so } \\
\text { that more people could garden. More places close } \\
\text { to home." }\end{array}$ \\
\hline David & Riverside & $\begin{array}{l}\text { "Right now I have some [fruits and vegetables] on } \\
\text { my balcony, but I grow them in everybody else's } \\
\text { yard. I'm like the shoemaker...we're growing in } \\
\text { Vancouver, a nice garden there, basically what I'm } \\
\text { doing is helping out and overseeing the plantings, } \\
\text { there is the Multnomah County garden and the } \\
\text { City Hall garden." }\end{array}$ \\
\hline $\begin{array}{l}\text { Susan } \\
\text { Seed to Supper Instructor }\end{array}$ & Bell Tower & $\begin{array}{l}\text { "The success is planting a small container garden, } \\
\text { a lot of people don't have a lot of space. More } \\
\text { space is needed to garden in." }\end{array}$ \\
\hline Elizabeth & $\begin{array}{l}\text { Assistant to } \\
\text { federally } \\
\text { elected } \\
\text { official }\end{array}$ & $\begin{array}{l}\text { "A key issue is the regulations on placement of } \\
\text { gardens...Where we place gardens is key. We are } \\
\text { working on legislation that would provide } \\
\text { financing either grants or loans for projects that } \\
\text { want to bring and that are going to provide fresh } \\
\text { food in underserved areas that could be grocery } \\
\text { stores but that could also be farmer's markets, } \\
\text { CSA's, etc... that one issue, from the garden } \\
\text { perspective... it is going to be partly federal and a } \\
\text { lot of the time this is going to be state and local, } \\
\text { making sure that regulations are changed so that } \\
\text { you can put a community garden in an area-so } \\
\text { that we're putting them in areas that make sense. } \\
\text { We need to put them in urban areas." }\end{array}$ \\
\hline Carol & $\begin{array}{l}\text { Elected } \\
\text { Official- } \\
\text { County }\end{array}$ & $\begin{array}{l}\text { "Evidence-based practices and the fact that we } \\
\text { can map and measure-that's a question we need } \\
\text { to really address and since the focus here is on } \\
\text { low-income people, ... really the point here is that } \\
\text { this (the Urban Food Movement) should be } \\
\text { accessible to everybody and the more we create }\end{array}$ \\
\hline
\end{tabular}




\begin{tabular}{|l|l|}
\hline & $\begin{array}{l}\text { space for community gardens and the more we } \\
\text { make it culturally okay-chuck out your lawn and } \\
\text { put in a raised bed garden there. The more access } \\
\text { low-income people will have... but how much } \\
\text { access that is, I don't know. And I think that has } \\
\text { to do also with access to grocery stores and the } \\
\text { cultural role as well. It has to do with access..." }\end{array}$ \\
\hline
\end{tabular}

Seed to Supper participants actively pursued alternatives when confronted with garden space limitations and the Seed to Supper program provided resources to reduce this barrier. Policymakers on the other hand, realize the impact of the barrier and the need for mapping (evidence) and regulation changes to free up access to more public lands for urban gardening (and shopping) for increasing access to local and fresh foods.

The following photos illustrate how the use of public space for community gardens for Seed to Supper helps alleviate the barrier of access for participants to grow and harvest fruits and vegetables (See Figures 13 \& 14). Community volunteers maintain the garden beds and the produce harvested by Seed to Supper participant volunteers goes to a food kitchen serving food insecure populations at Riverside Court. 
Figure 13. Multnomah County Ecoroof Community Garden

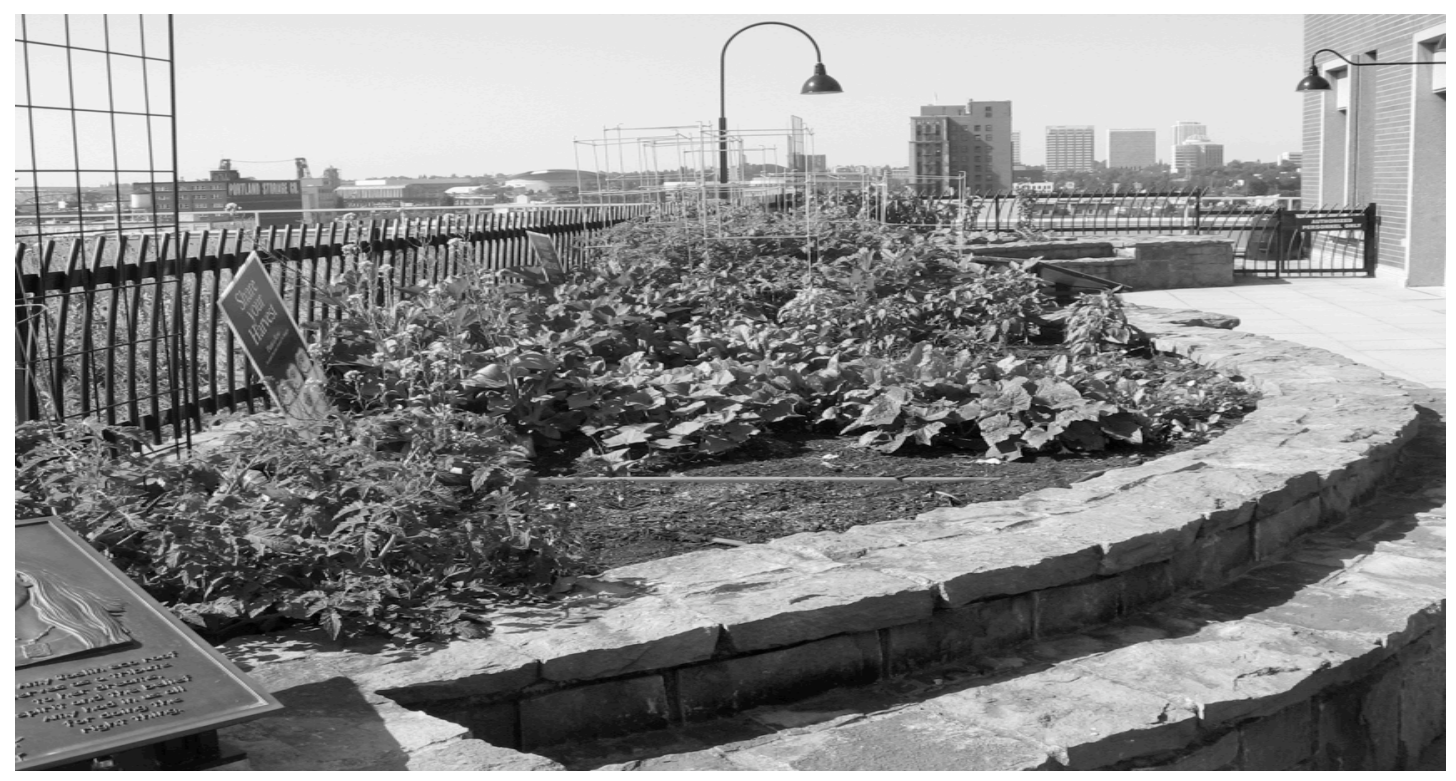


Figure 14. City Hall Community Garden

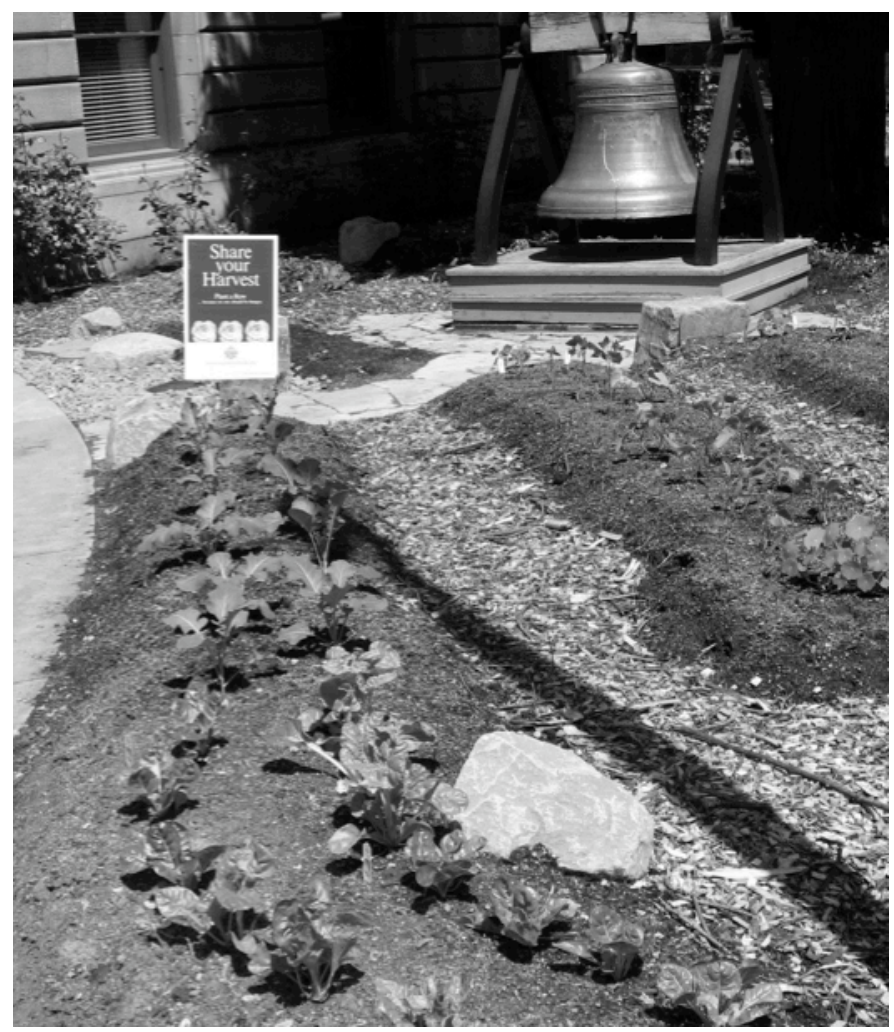

Seed to Supper participants have access to the produce raised in both of these public spaces, which the City of Portland and Multnomah County have been dedicated for use by food insecure communities. Regulation for increased use of public lands for urban agriculture helps alleviate the barrier of access to garden space.

Transportation

Although the majority of the participants interviewed reside in public housing projects and have a degree of stability in their lives, the issues of cost, a space to garden in, and transportation were major barriers to accessing fresh fruits and vegetables. Some of the participants have problems with access to affordable discount grocery stores like WinCo (Stands for: Washington, Idaho, Nevada, 
California and Oregon), and Food for Less, due to the lack of transportation. Public transportation was viewed as too cumbersome for shopping long distances from their home.

In a few of the communities, I observed shared transportation options such as carpooling and organized field trips to farmer's markets, Community Supported Agriculture sites, nurseries, and large discount grocery stores. The ability of the participants to share costs of transportation or to create alternative means of accessing food depended on a sense of community and members who facilitated these activities. For example, one participant biked from community garden to community garden in order to harvest produce. During the summer he delivered vegetables to the meal kitchen daily. During our interview, we walked to a bike shop and he showed me the bicycle he wished for. It was a large city bike with huge produce saddlebags on each side. He was confident that eventually he would deliver produce with that bicycle.

Most participants shop at the grocery store nearest to their home due to limited transportation as shown in responses to interview question five: "Where do you purchase or obtain most of your fresh produce?" The responses revealed where participants obtained their fresh produce. One interviewee belonged to a Community Supported Agriculture (CSA) organization and occasionally shopped at New Seasons (a local grocery store known for its excellent selection of locally grown foods) and Trader Joes. Only two people shopped at farmer's markets, and all interviewee mentioned that farmer's markets are too expensive. All interviewees 
indicated they shop at the supermarket closest to where they live: primarily Albertsons and Safeway (see Figure 15).

Figure 15. Seed to Supper Participant Interviewee Shopping Patterns

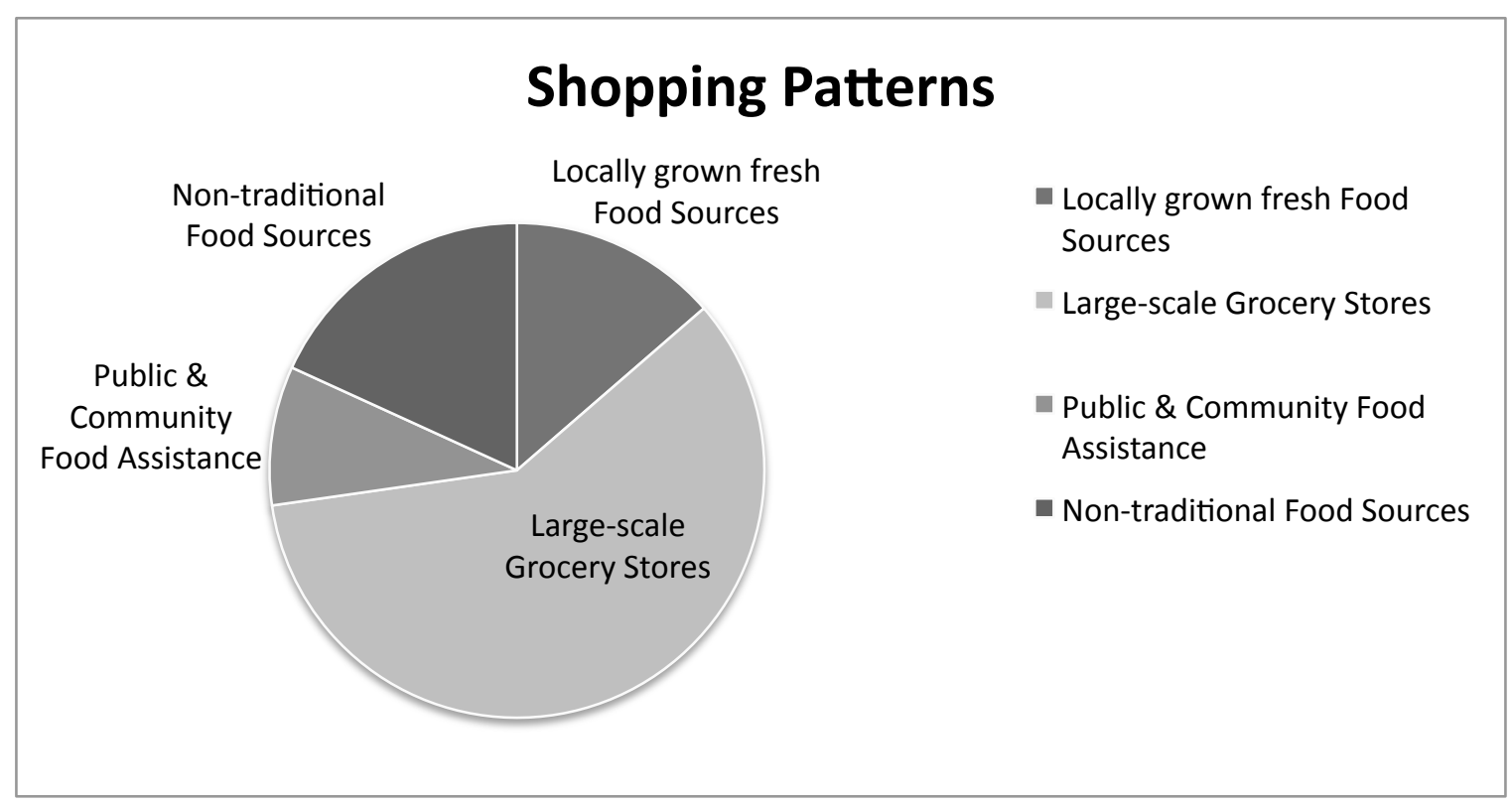

$n=9$

The interviewees indicated that they shopped at these stores because of convenience, not necessarily because they are less expensive. WinCo was often mentioned as a shopping place to find good value-but getting to a WinCo store is difficult for most, because they rely on public transportation. Several of the interviewees said they preferred fruit and vegetable stands to farmer's markets and three participants regularly shop at local fruit stands because of freshness and good prices. Traveling to fruit stands was an issue for them all, but they felt it was worth the savings if they could get there (Withers, 2010). See Table 20 for samples of comments related to transportation. 
Table 20

Selected Comments from Seed to Supper Participant Interviewees Related to Transportation

\begin{tabular}{|l|l|l|}
\hline $\begin{array}{l}\text { Seed to Supper Participants } \\
\text { Groups 1 \& } 2\end{array}$ & Site & Comment \\
\hline David & $\begin{array}{l}\text { Riverside } \\
\text { Court }\end{array}$ & $\begin{array}{l}\text { "I go out of my way, I get on the train and go out to } \\
162^{\text {nd }} \text { to Grower's Outlet. I get onions for .39 } \\
\text { cents per pound, sometimes I get cucumbers, 4 for } \\
\text { a buck and they have great produce. Normally, } \\
\text { they're open 7am - 7pm ... and it's all local, I bet. I } \\
\text { get milk there; it's hormone free. I believe there is } \\
\text { a difference in the taste of the milk and the } \\
\text { vegetables out there, the tomatoes, the Romas, I } \\
\text { pay more in town than out there. It's worth it to } \\
\text { get on the train." }\end{array}$ \\
\hline Christine & Brookplace & $\begin{array}{l}\text { "Cost and transportation influences my decision } \\
\text { to buy fruits and vegetables and availability. I } \\
\text { used to be able to walk, but now I can't, it's just } \\
\text { too much. I used to have a cart. If I have to take } \\
\text { the bus, go downtown cross the tracks, wait for } \\
\text { the bus to get to Albertson's I have to put in as } \\
\text { much time with transportation each way as I do } \\
\text { for shopping. One winter, I had a very bad } \\
\text { experience in the cold waiting for bus and became } \\
\text { very ill as a result, I'll never forget that." }\end{array}$ \\
\hline $\begin{array}{l}\text { "Transportation is hard, they [Seed to Supper } \\
\text { participants] need to live close to their } \\
\text { garden...even buying fresh food at the grocery } \\
\text { store can be an issue." }\end{array}$ \\
\hline Instructor & Bell Tower \\
\hline
\end{tabular}

The following community members and leaders shared comments about the importance of access to transportation for food insecure communities. The lack of available transportation creates barriers for accessing fresh locally grown foods. Both of these on-site services coordinators have first hand knowledge about the impact of this issue on food insecure populations (see Table 21). 


\section{Table 21}

The Impact of Limited Transportation Options on Food Insecure Communities

\begin{tabular}{|l|l|l|}
\hline $\begin{array}{l}\text { Community members and } \\
\text { leaders Group 3 }\end{array}$ & Site & Comment \\
\hline Helen, site services coordinator & Brookplace & $\begin{array}{l}\text { "In terms of improving people's access to locally } \\
\text { grown foods, transportation is really key, } \\
\text { especially at Forest Hills. Being able to get to the } \\
\text { (closest) farmer's market is even a struggle } \\
\text { because of limited bus service up there. There is } \\
\text { no service on the weekend, which is when the } \\
\text { farmer's market takes place...it (transportation) is } \\
\text { a barrier to all sorts of things, especially for } \\
\text { getting fresh foods. There's a close-by food } \\
\text { market, but it's really expensive." }\end{array}$ \\
\hline $\begin{array}{l}\text { Misty, Services and garden } \\
\text { coordinator }\end{array}$ & Cascade View \\
Pantry & $\begin{array}{l}\text { "This neighborhood is on the edge of the city - the } \\
\text { bus lines and routes are limited and } \\
\text { transportation is a barrier. Developing } \\
\text { access/transportation to the farmer's markets is } \\
\text { important for members of our community." }\end{array}$ \\
\hline
\end{tabular}

These selected first-hand observations and comments from site coordinators indicate how significant transportation barriers are for food insecure populations, especially in accessing locally grown foods. Many of the participants rely solely on public transportation and many areas of peri-urban Portland do not provide regular public transportation on weekends or if they do, it is very limited. For Seed to Supper participants, this limits access to farmer's markets, food coops, CSA's and other alternative shopping options, inhibiting access to locally grown foods. The next section focuses on the overall issue of economic hardship and the impact on Seed to Supper participants.

\section{Economic Hardship}

Economic hardship is the biggest hurdle to overcoming food insecurity. Addressing this barrier is difficult in terms of the scope and scale of this study, but 
nevertheless warrants discussion. This barrier impacts all aspects of food security including finding or creating garden space, paying the annual fee to join a community garden, buying plants or seeds, buying locally grown produce and foods, education costs, and buying gas for transportation to access a community garden, a nursery, or grocery store. The results discussed below raise additional questions and focus on the overwhelming reality of social inequity for food insecure populations. This next section reflects the attitudes and opinions from the survey participants, interviewees and observations from my fieldwork.

The survey results revealed the four main barriers (see Figure 10), three of which I have addressed in the preceding sections. Although this study found the Seed to Supper program goals-building self-reliance, improving nutrition and increasing community food security—provided pathways to increase food security, the challenges of economic hardship are major factors in preventing food security.

In order to address research question three: "Do these goals accomplish the overarching need for increased food security in urban and peri-urban Portland?" I ask a related question: "are the Seed to Supper program goals alleviating food insecurity?" In order to answer this question, it is important to understand how the program addresses the barriers to food security. A number of themes contribute to improving food security including community building, place-based learning, learner empowerment, building self-reliance, food literacy and greater social capital (discussed in next section). Additionally, the main program goal-to achieve community food security—is primary, while building self-reliance and improving 
nutrition are secondary goals. The latter goals are strategies to achieve the main goal of food security. This distinction is important. Historically, learning gardens have been viewed as remedial in nature, as noted in the literature review, and have stressed building self-reliance and self-sufficiency—hands-on learning and increasing access to gardening knowledge (Lawson, 2005).

However, as the Riverside Court instructor stated, gardening and farming are the heritage/legacy of many cultures in the Willamette Valley as well as the culture of recent emigrants. Self-reliance and self-sufficiency are inherent to these populations. What I found from the participant and community member interviews is that in order to create local community food systems, more resources, such as funding, transportation, and motivation/incentives are needed to connect with other community members to build community food systems. The Seed to Supper program sites examined for this study appeared to be more successful in creating "community" and the networks for community food systems than many middle class neighborhoods in Portland. While technically, food security is most likely higher in these middle class neighborhoods, this is most likely due to higher economic incomes and greater resources than to any community building efforts; this point could can be argued given all the neighborhood efforts to build community in Portland, Oregon.

Several community leaders were aware of this distinction between the cultural and economic impact on neighborhoods, however, they felt that is was their mission to facilitate a "major food paradigm shift" (Carol, elected official). Several 
community leaders felt increased economic impact could only come from a major shift in government funding that would change how farm subsidies are allocated by altering the 2012 farm bill. Additional improvements could be achieved through local, and state efforts to reform land use policy and to create local solutions for alleviating food insecurity. The garden instructor and leader at the Riverside Court felt that a combination of food literacy and grassroots organizing directly with food insecure populations could alleviate food insecurity with the greatest success.

Another talented and effective services coordinator felt that building a community food system through the learning garden provided hope for the populations she worked with. Additionally, she felt the garden provided an opportunity for participants to learn to get along with others and how to overcome differences and cultural barriers were imperative to building a food secure gardencommunity. She states, "every day participants face the difficult choices of how to use their resources and live with economic hardship." She continues to say that instilling some hope and providing food alternatives to the members of the communities were some of the main goals of the instructors and coordinators directly dealing with the Seed to Supper populations.

All of these observations, comments and suggestions point to the importance of coalescing community interests and building stronger community ties, ultimately leading to food democracy and food justice in overcoming economic hardship.

The notion of instilling hope and providing food alternatives segues into the fourth question: "how does the Seed to Supper program impact improved food 
literacy, self-reliance and create social capital?" Asking Seed to Supper participants directly about food literacy, self-reliance or social capital was not an option for this study due to the semi-structured interview questions relating to the survey and the decision to keep the inquiry less invasive. However several open-ended questions focused on sharing a story or experience about the Seed to Supper program. And often throughout the interviews, participants would share stories about growing food, buying produce and how these activities played out in their lives and how they personally impacted socially and economically. By being present at the sites and spending the past three years visiting, observing, participating and learning along side participants, I have gained an understanding about how their lives relate to the learning gardens. These on-going discussions and observations helped to shape my perspective on the findings related to research question number four.

\section{Overview to Question 4}

Question four asks: "Does the Seed to Supper program improve food literacy, self-reliance and create social capital?"

Question four focuses on improved food literacy, self-reliance and the social capital that was created through the Seed to Supper classes, workshops and the partnerships formed.

\section{Food Literacy}

Food literacy means possessing knowledge about where food comes from and how we access food-literally how it is grown, harvested and prepared (Nordahl, 2009). Although garden-based learning and sustainability education are closely 
connected to food literacy, when the term "food literacy" is used, it refers to the culturally embedded aspects of food derived from collective and individual memories about the food our families grew, prepared and ate. Although several generations may not have lived on a family or a commercial farm or even near an urban garden, the connections are often still alive.

The survey results illustrate the overall positive impact of the Seed to Supper program impact on food literacy, with $92 \%$ agreeing that the workshops taught them something that they would use in their gardens (see Figure 3). The fourth survey question, "I have gained enough experience to grow some of my own fruits and vegetables" showed that 79\% agreed (see Figure 16).

Figure 16. Participants Agree They Have Enough Experience to Grow Some Fruits and Vegetables

\section{I have gained enough experience to grow some of my own fruits and vegetables.}

\begin{tabular}{|c|l|c|c|c|}
\hline$\#$ & Answer & Response & $\%$ \\
\hline 1 & $1-$ disagree & 6 & $3 \%$ \\
2 & $2-$ maybe & 37 & $18 \%$ \\
3 & $3-$ agree & 159 & $79 \%$ \\
\hline & Total & 202 & $100 \%$ \\
\hline
\end{tabular}

$\mathrm{N}=202$

These results indicate that the Seed to Supper program has impacted the participants by improving their gardening knowledge and food literacy. The survey results show that $59 \%$ of the participants had grown some food in the past two years (see Figure 17). 
Figure 17. High Percentage of Seed to Supper Participants Have Grown Food Within Two Years

6. Within the past two years I have grown some food.

\begin{tabular}{|c|l|c|c|c|}
\hline$\#$ & Answer & & Response & $\%$ \\
\hline 1 & $1-$ disagree & 51 & $27 \%$ \\
\hline 3 & $2-$ maybe & & 27 & $14 \%$ \\
\hline & $3-$ agree & & 112 & $59 \%$ \\
\hline & Total & 190 & $100 \%$ \\
\hline
\end{tabular}

$\mathrm{N}=190$

A majority of the Seed to Supper participants had existing gardening knowledge prior to the Seed to Supper classes, indicating some degree of food literacy. However, the garden based classes and workshops better prepared them to deal with garden issues such as pest management, seasonal planting cycles and other dilemmas gardeners face.

In survey question 5, 64\% indicated they would accept more gardening advice and gardening training if it were available (see Figure 18). Within this population, access to gardening knowledge and food literacy is welcomed and anticipated.

Figure 18. Seed to Supper Participants Would Like Additional Training

\section{I would like more gardening training.}

\begin{tabular}{|c|l|l|c|c|}
\hline$\#$ & Answer & Response & $\%$ \\
\hline 1 & $1-$ disagree & & 18 & $9 \%$ \\
2 & $2-$ maybe & 53 & $27 \%$ \\
3 & 3 - agree & & 124 & $64 \%$ \\
\hline & Total & 195 & $100 \%$ \\
\hline
\end{tabular}

$\mathrm{N}=195$ 
These survey results indicate an informed population receptive to gardenbased learning and food literacy. The interviews further demonstrate the existing knowledge base and willingness to share within their communities. Seed to Supper populations demonstrated knowledge and the desire to access more garden-based learning through the Seed to Supper program, each other and their community resources.

Many of the stories about farm life, or gardening remain embedded in the collective memories through family lore shared by grandparents, parents and other close family members (Nordahl, 2009). Traditional communities, both indigenous and historically agrarian cultures have passed down gardening and food literacy knowledge (LaDuke, 2005; Nordahl, 2009; Parajuli, 2002). The following examples illustrate a few Seed to Supper participants that have strong connections to embedded garden-based knowledge.

"I love the taste of my homegrown tomatoes," exclaims Bill, a part-time gardeners at Brookplace. "I don't have a lot of time, but I grow all my tomatoes and onions." He explained that his parents were farmers in Japan and they grew all of their own food. Now, as a returning college student, he is pursuing a degree in computer software programming, but having access to better tasting food is the main motivation he participates in the community garden at Brookplace. Although a small portion of his diet is homegrown, he is aware of his preference for fresh tomatoes and other vegetables, and finds a way to access other fresh foods that he is accustomed to at an Asian market located at the peri-urban fringe of Portland. 
Another Seed to Supper participant, David, has a history of farming experience and knowledge and he takes an active leadership role in his community by assisting with classes and harvesting produce for the meal center where he volunteers. He shared that, as a child, his family was "very poor," but they always had food on the table because they raised all their own food. He exclaimed, "we milked the cows and every day collected eggs from the chickens. We grew all our greens and potatoes. I remember all that!" They did not experience food insecurity, but they were "very poor."

The interviews revealed that most of the participants had food literacy that went back to their childhoods. Most had direct experience with farm life, a garden plot or a close family member who imparted gardening knowledge to them. These memories were vivid and gave them motivation to grow food now. The Seed to Supper workshops and classes were enriching reminders of their own food culture.

The confidence that comes from knowing how to plant a package of seeds and to use compost and other soil amendments to help them grow is very empowering. In an interview with another participant she expressed her gratitude for learning about the connection between soil amendments and enriching the soil; she referred to the process as a "milagro" (miracle). This participant was previously a farm worker and she spoke passionately about growing her own food on a small scale. Although she had experience in a commercialized farm setting as a farmworker, the Seed to Supper classes taught her about the soil and the amendments needed to create healthy microorganisms. She spoke of her reluctance 
to add chicken manure to soil that would produce food she gave her children. But once she understood how it improved the soil she realized its importance. She gained respect and expressed wonderment for the miracle of growing things. The miracle of gardening and the awe of growing your own food is an important component of food literacy and sustainable education (Withers, 2010).

Understanding the impact and challenges of diversity within food insecure populations is important for analysis of food literacy. When asked what she meant by cultural food shift, public official Carol passionately described her observations about the many diverse cultural groups locating in the Portland region that have closer connections to farming and food production than many of our local dominant culture. She saw this diversity as an opportunity to create cultural exchanges that could lead to a "cultural food shift or paradigm shift." She referred to the need for a paradigm shift in order to create greater local access and systems for locally grown foods. She continued by describing the need to move from "processed to fresh foods" and the enormous task of educating the public about the benefits of fresh foods. She cited economic barriers and the cultural influences of the media-including the constant exposure to cheap processed foods advertised on billboards and on television—as major obstacles to a healthier local food system. People have come to expect convenience and speed. She pointed out that one key resource for improving this situation could come our diverse populations. She suggested these populations have a lot to teach us. She asks the question, "How can we access this knowledge?" She felt the community garden is a place where the cultural barriers 
can be crossed and we can benefit from learning about new foods and food preparation.

To add a different perspective on food literacy, Brookplace services coordinator Helen stated, “People really don’t have access to fresh locally grown foods without a community garden and a lot of people are not able to participate in a community garden without the education programs to support them in doing that, unless they happen to be from a community where people have historically gardened like at Brookplace; a place where we have a big group of immigrants and seniors who grew up with the idea of gardening. But if you grew up in neighborhood that didn't have that history, and the education programs are not provided, there will be people who are not comfortable participating in gardening. It is something so new them, not something you can be successful at without some basic garden knowledge.

Participant Profile: Food Literacy

Becky resides at Brookplace. She has been involved with the community garden since its inception. Her mother gardened and Becky assisted her as a young girl, but did not actively garden until she moved to Brookplace. She is now an active volunteer there and has become an on-site cooking instructor, helping the residents adapt fresh garden produce into their diets. To facilitate learning and learner empowerment, she offers group classes, but also works one-on-one with members who have special dietary needs. As an educator and organizer, Becky is an example of a Brookplace member who has embraced food literacy and created a leadership 
role in the community. Recently, she shared with me that she had overcome her battle with type-2 diabetes and had controlled the diabetes through dietary and exercise programs. She courageously told her story in public at the 2011 Multnomah Food Summit and attributed this to her active lifestyle and involvement in growing as much of her own produce as she could and by utilizing healthy foods available through Oregon Food Bank's programs.

Very often the participants of the Seed to Supper program already have active community gardens and possess collective gardening knowledge among their community members. Many of the Seed to Supper participants who had a high level of food literacy possessed confidence about their participation in the learning garden and felt connected to their food heritage. Their participation in the community garden manifested greater food literacy and empowered other members around them with personal food security as well. These individuals often took leadership roles in passing knowledge along about growing food and accessing food.

\section{Self-Reliance}

The Community Food Security Coalition states on its website, "Community food security projects emphasize the need to build individuals' abilities to provide for their food needs. Community food security seeks to build upon community and individual assets, rather than focus on their deficiencies." How do we measure selfreliance? While it is difficult to quantify self-reliance, the survey used in this study asked participants to share their stories about gardening. Many of the stories focused on the pride and joy of growing a good tasting vegetable, as well as 
increased community activities and celebration of food through harvesting, weeding parties and the classes (see Table 15). The following survey responses show the impact the program has had on building self-reliance.

Survey question three asks Seed to Supper participants if they grow some of their own produce. This question focuses on whether participants were using garden-based learning and putting it to use. Figure 19 shows that $78 \%$ grow some produce. This leads me to conclude that a majority of the Seed to Supper participants possess self-reliance, and as the previous section on food literacy suggests, they already possess self-reliance. However, it is likely that the program imparted additional knowledge necessary for them to grow their own produce. Figure 19 Percentage of Seed to Supper Participants that Grow Produce

\section{I grow some of my own produce.}

\begin{tabular}{|c|l|c|c|c|}
\hline$\#$ & Answer & Response & $\%$ \\
\hline 1 & $1-$ disagree & 19 & $9 \%$ \\
2 & $2-$ maybe & & 25 & $12 \%$ \\
3 & 3 - agree & 157 & $78 \%$ \\
\hline & Total & 201 & $100 \%$ \\
\hline
\end{tabular}

$\mathrm{N}=201$

Many of the survey results supported the impact on self-reliance through greater learner empowerment.

One example of building self-reliance through the Seed to Supper program took place in a HeadStart program was previously discussed in an earlier section on place-based learning. The teacher, and Seed to Supper participant, Terry told me about the success and popularity of a container gardening class she helped to 
arrange. She was surprised when 25 people arrived (the parents and children) to learn how to grow tomatoes, basil, and salad makings on their balconies and in their small yards. In addition to using the school curriculum with a hands-on activity, the families were taught skills that could lead to greater access to fresh grown foods. The instructor felt involving families provides role modeling for self-sufficiency and self-reliance.

Misty, the garden coordinator at Cascade View food pantry felt the Seed to Supper program had "done wonders for many of the participants in her learning garden program." One of the gardeners at her facility had shared with her that "participating in this garden is why we have fresh foods." She was encouraged because her children actually like vegetables and she felt it was due to the hands-on experience of growing their own produce. Many of her clients would not have access to this much locally grown food otherwise. One of the first things she told me was that the Seed to Supper learning garden concept helped "increase selfsufficiency and enhanced their experiences in the garden."

Another garden coordinator interviewed for the study emphasized that giving people a chance to grow their own food would foster pride, independence and hope; she said it was better than, "just showing up for free food." The added value of self-reliance versus free food played a role in the culture of the service providers and program coordinators, and policy makers of the emergency food services and programs. In the interviews, elected government officials, Oregon Food 
Bank leaders, instructional leaders and the community services coordinators stressed the importance of imparting self-reliance in the Seed to Supper program.

Another venue that warrants mention is City of Portland's Bureau of Planning and Sustainability's annual neighborhood FIX-IT Fairs held throughout the city. The fairs honor and promote healthy families, healthy homes and offer free workshops, classes and information tables. These fairs are targeted to food insecure populations. At each of the fairs, located throughout the Portland Metro regions, the Seed to Supper program offers gardening, composting, and container garden workshops. The workshops and demonstrations are packed with participants generally 30-40 people attend these workshops eager to gain specific vegetable gardening basics for the Pacific Northwest. The interest in learning how to garden and improve gardening technique is evident by the questions asked in the workshops, which varied from basic beginning gardening techniques to more advanced questions on crop rotation, soil amendments and harvesting. The Seed to Supper participants are eager to develop greater skills leading to greater selfreliance and self-sufficiency. The FIX-IT Fair is a successful venue for providing Seed to Supper program's gardening knowledge to an eager audience.

Participant Profile: Self-Reliance

David, an active volunteer at the Riverside Court discussed how important the Seed to Supper program has been in his life. He shared his feelings of selfsufficiency, satisfaction, comfort and security. He has gained satisfaction from assisting the program by harvesting and delivering produce on a daily basis to the 
scratch kitchen at Riverside court. Interestingly, David was a member of the Future Farmers of America as a young person, and has gardened all this life. He felt giving back to his community enhanced his experience as a garden volunteer and provided him a leadership role. This involvement brought greater meaning and comfort to his life. His sense of self-reliance impacted his community through his on-going volunteerism to impact access to local foods.

The survey results, interviews and field observations lead me to conclude that a majority of Seed to Supper participants gain more confidence, knowledge and independence through participation in learning garden programs.

\section{Social Capital}

The last aspect of question four focuses on social capital. One definition of social capital is "the value of social networks, bonding similar people and bridging between diverse people, with norms of reciprocity" (Dekker \& Uslaner, 2001, p. 2). Social capital is an important concept related to the success of community food security projects. The national Community Food Security coalition sees social capital as integral and "seeks to engage community residents in all phases of project planning, implementation, and evaluation" (n.d. para \# 6). The empowerment needed to motivate individuals to take on leadership roles within their communities, can lead to not only social capital, but also food democracy and food justice. Mobilizing people in food insecure communities to take action and make change is a main motivator for the site coordinators and policy officials supporting programs like the Seed to Supper. Based on the survey, interviews results, as well as 
my observations, I conclude the learning gardens provided opportunities for building social capital, which is closely related to community building. The following section briefly discusses several communities that have improved food security through building pathways to greater social capital and providing opportunities for citizen involvement in food justice issues.

Perspective of an Engaged Community Food System

The concept of social capital is important this study's effort to identify factors that lead to engaged community food systems. One community that has achieved greater food security is Brookplace. The community learning garden has become central to its engaged-community food system that uses multiple partnerships to provide opportunities to share and learn about food security. The economic benefits to the community have been numerous. There are more raised garden beds, a mature blueberry patch provides fresh blueberries and the future goal/dream is to develop and plant a community fruit tree orchard. This past summer a Portland State University senior capstone class worked with community members to build a composting system for the learning gardens and in the fall Brookplace held their first community Health Fair-described in Chapter One's Learning Garden Scene 1. The community services coordinator has obtained numerous county and city grants to help the learning garden expand its infrastructure and its educational programs.

The social capital generated around the Brookplace learning garden is evident and on a summer day-it is pleasant to visit the gardens, talk with 
gardeners, share stories and, if lucky, a community potluck is taking place. For many members, having these opportunities to eat healthy foods, in close proximity to their home is critical due to transportation issues, economic hardship, health issues and comfort levels. Attending events in their garden is similar to spending a day at one of Portland's farmer's markets. The economic goals are certainly different—but the social capital gained is similar. The smiling faces, children playing and shared community experience brings greater food security with the added value of some of the trappings of economic advantage.

Several community leaders and educators referred to the goodwill that is fostered by learning garden programs, and asserted that this type of community building may be more important than the garden skill building. One prominent community garden leader, involved in Portland's community garden programs since the 1970s, stated that she focused on building democracy and citizen involvement through community gardens. Regardless of the terminology used, city officials, state and federal government leaders increasingly recognize the social capital benefits of community garden programs.

Site Profile: Lakeview Correctional Facility Learning Garden Project

Once the learning garden at Lakeview Correctional facility took root, the volunteer Seed to Supper instructors described how effective the program became in impacting access to fresh and locally grown foods for the incarcerated participants. The garden has doubled in size and the on-site kitchen has incorporated the fruits and vegetables into the meal plans. After a convincing demonstration of how the 
garden impacted the incarcerated participants, the kitchen staff embraced the learning garden program and suggested they help write a "Healthy Foods" grant to build a greenhouse to expand the capacity of the garden. Building on success, a partnership between facility staff, volunteer instructors and the participants' work collaboratively in a unique setting where social capital improved as a result. The Lakeview Correctional Facility is also a Portland State University Capstone site for the class entitled: “Women's prisons and Organic Gardening” providing another opportunity for a partnership to improve access to locally grown foods.

\section{Conclusion}

This study has examined whether learning garden programs such as the Seed to Supper Program increase access to locally grown food and successfully include and empower food insecure people and their communities.

The Oregon Food Bank's focus on the learning gardens and advocacy has helped food insecure citizens' access food security by gaining critical knowledge by improving food literacy, which creates opportunity for empowerment (self-reliance) and economic advantage (social capital). These pathways to greater food security often led to greater food democracy (citizen involvement) and created increased social capital. Once these patterns were established in the communities included in this study, the external and internal partnerships also provided leadership opportunities for capable members of the communities. The final chapter discusses the implications of the findings presented here. 


\section{Chapter 5: Discussion, Implications for Practice \& Conclusion}

\section{Learning Garden Scene 5: Community-Based Learning and Food Democracy}

On the final day of the Portland State University (PSU) Capstone class, "Food, Democracy, and Sustainability," the residents of Brookplace prepared a celebration meal for the students of the capstone. I arrived at Brookplace for the celebration to the smell of BBQ turkey burgers and to a table of salads, condiments, fruit and beverages. Everyone was excited about the new composters built by the students over the eight-week period. The celebration took place next the garden beds and they were beautiful with flowering vegetables, vining tomatoes, corn, and herbs everywhere. We took group photos and I had a hard time fitting the whole group into the frame: there were over 30 people, gardeners, students, grounds staff, the on-site coordinator, and visitors.

Using community-based learning principles, the capstone course connected Portland State University students with the local residents to complete projects for Brookplace and Forest Hills. The students studied literature about sustainable community food systems, food justice and food democracy. Their assignments were rigorous and included content about the process and the science of building composters, as well as the literature describing food justice.

The PSU course objectives addressed food democracy and food justice within the context of building a local partnership between the PSU students and the residents and Seed to Supper participants at Brookplace and Forest Hills. Forest Hills wanted educational signage (plant identification) for their learning garden, 
which includes a children's garden, a greenhouse, fruit trees integrated throughout the plot, and a community composting area. As the partnership unfolded, the composting systems and signage were designed and built by the PSU students with the oversight, input and participation of the community members. This communitybased learning setting sets the scene for chapter 5 and a discussion of the impact of the Seed to Supper program on food insecure populations through community building and partnerships.

Chapter five focuses on the successes of the Seed to Supper program and the implications for best practices that emerged from this study. This discussion builds on the results of Chapter 4 by further exploring the findings about the impact of learning garden programs on food insecure people and on their access to locally grown foods. Furthermore, this discussion describes the implications for empowering food insecure populations through active citizenship and pathways to food democracy and food justice.

To begin, I explore the Seed to Supper program's external and internal partnerships by using a concept known as the "web of inclusion" (Helgesen, 1990; 1995). Building on this concept, I discuss the role of community-based partnerships and the integration of sustainable leadership in the web of inclusion (Helgesen, 1990; 1995). Several of the research sites included in this study manifest organizational and social behavior patterns associated with the web of inclusion. As I discovered, many of the program outcomes can be attributed to these patterns. 
In this chapter, I also posit implications and best practices in the following three areas:

1) Programmatic methods for sustainability and garden educators;

2) Barriers and policy recommendations for community leaders and the public service sector; and

3) Suggestions for fostering citizenship and creating pathways to food democracy and food justice.

In concluding, I focus on the impact of community-based learning in educational research settings, and describe the benefits gained by the academy when it engages with external community organizations and partners with food insecure communities. Lastly, I reflect on the significance of the study for me personally and next steps for further research.

\section{Web of Inclusion, Integrated Partnerships and Sustainable Leadership}

The lack of food security has developed over many decades of economic and agricultural policies that have created a global (large-scale and centralized) food system that has disrupted local and sustainable community food systems. Large-scaled food systems have created barriers for access to locally grown and culturally appropriate foods for many populations (Poppendieck, 1998; Winne, 2008). Contrary to today's large-scale, globalized, corporate food systems and to what many conservative policymakers purport, the findings of this study indicate that local sustainable food security is achievable when certain key practices are employed. In the following section, I introduce the central concept 
of the "Web of Inclusion," (Helgesen, 1990) which helps explain how integrated partnerships and sustainable, "social system networks" (Senge, 1990) promote local, sustainable, community food security.

The findings of this study showed that the learning garden sites utilized a network of partnerships that exemplified whole system designs and systems thinking principles (Mollison, 1988; Senge, 1990). Borrup (2006), Flores (2006) and Goldbard (2006) write about community development in various disciplines and help define "community" and "community development" or "community building" (the term used for this paper) as creating culture within the definition of a geographical space; a place defined by its boundaries. The work of organizers and community members collaborating to express, build and expand cultural social change can be defined as "development" (Goldbard, 2006). Closely related to this definition of community development and building is the concept of ecological design processes or "permaculture" (Mollison, 1988; Hemenway, 2009; Flores, 2006; Holmgren, 2002). Flores states, "using ecological design processes to organize community projects bring the ecological ethics" (p. 218) that are embraced through community building in the garden, [and] by "developing a detailed action plan helps ensure smooth implementation" (p. 218). By using ecological design practices such as goal setting, observation, recognition of boundaries (or edge), identifying resources, analysis, design, sector analysis, and evaluation (feedback loops) organizers can foster successful activities for food insecure communities. 
The learning garden sites in this study also mimicked what Helgesen (1995) has defined as the "web of inclusion." Helgesen (1995) has identified an organizational style that integrates nurtured relationships, open lines of communication and less hierarchical ranking. She discovered that "women tended to put themselves at the center of their organization rather than at the top" (p. 10). This deliberate circular pattern of communicating and inclusion in the decisionmaking process fostered nurturing environments that lend themselves to more interconnected systems (Helgesen, 1990). Helgesen cites Capra's theory of "an interconnected web" with endless connections and mutually reliant factions that are related to our universe, affirming the value and importance of every fragment. These concepts of connectedness support the goals and precepts of sustainability education; many of these patterns of connectedness were identified in the research sites for this study.

In addition to the web of inclusion communication model, Gaylie (2009) found that the learning garden was often a place of transformation. She means this both metaphorically for the individuals working in them, and physically, as gardens are transformed "from junk piles to organic garden[s]" (p. 99). When the web of inclusion model was present in the Seed to Supper learning garden communities, opportunities for transformational change led to successful gardening and often more leadership opportunities. These opportunities for transformation and sustainable leadership roles provided more human resources, volunteerism, and 
stronger communication linkages and provided avenues for self-reliance and responsibility within the learning garden communities examined in this study.

Figure 20 illustrates the internal web-like community networks used at Brookplace, as opposed to the top-down hierarchical structures typically found in many organizations and communities (Senge, 1990). Smith, (2001) states that Senge's theory focuses on the decentralization of leadership in organizations. Decentralizing leadership roles enhances the capacity of all people to work together towards common goals. The figure below illustrates how this "web" or "decentralization" works within the context of the learning garden community sites. 
Figure 20. Web of Inclusion At Brookplace

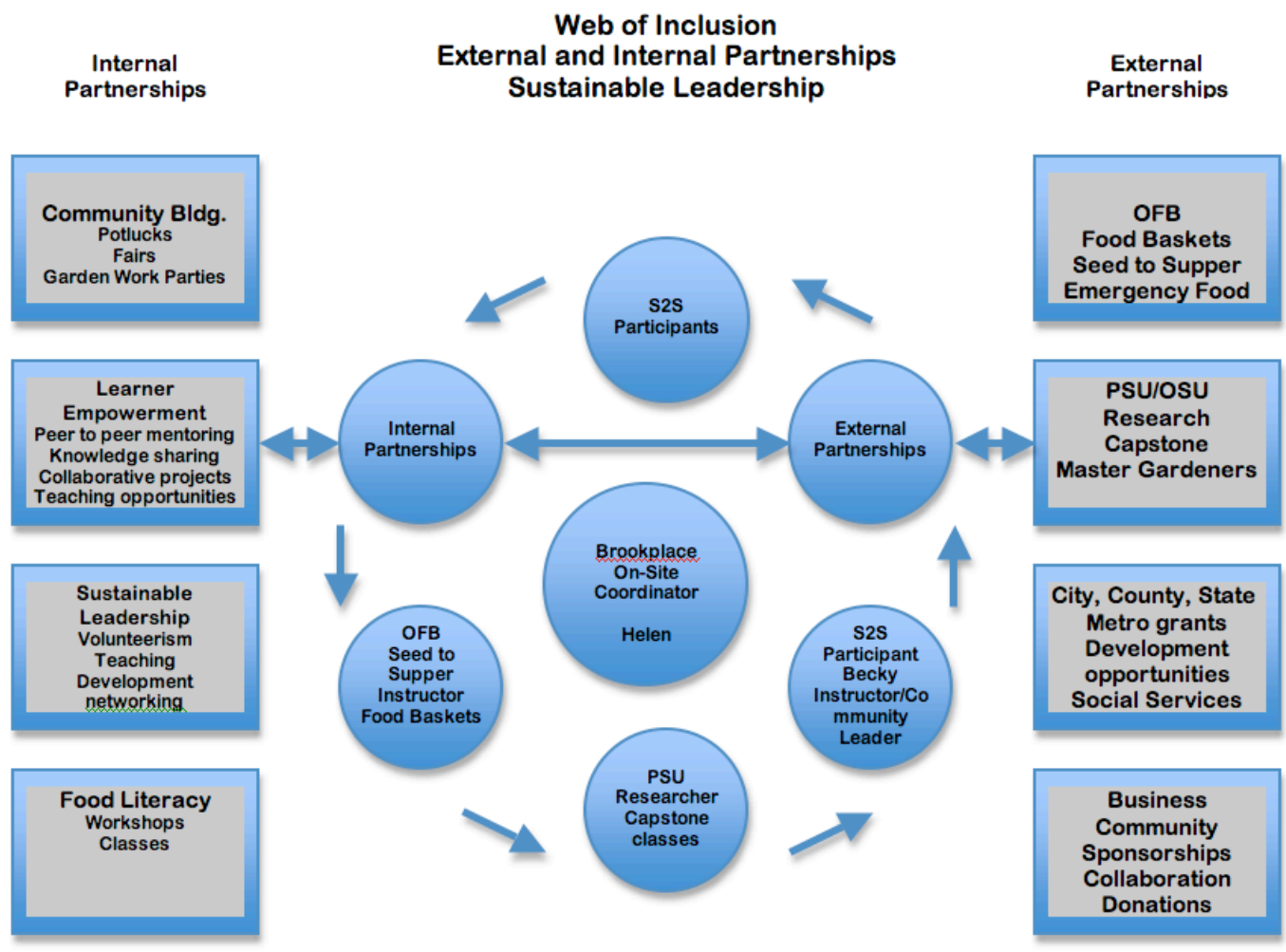

In figure 20 , the web in the center shows the site interrelationships with the internal and external partnerships on either side of the web. The internal partnerships correspond to the main patterns that appear in the study's findings: community building, learner empowerment, sustainable leadership and food literacy. The external partnerships illustrate resources and services available to the site from outside sources. The interactions among all of these interrelated systems create the web of inclusion identified in this study that contributes to increased food literacy, self-reliance and social capital. Additionally, the web of inclusion sets the scene for engagement in food democracy and participatory citizenship. 
Gaylie (2009) maintains that learning gardens provide opportunities for democratic processes. Similarly, the web of inclusion allows for these democratic processes and can be compared to Capra's web of life theory, which focuses on interconnectedness and ecosystems (Capra, 2002). In Helgesen's (1990) study, she found "ecological" leadership patterns in the women leaders and their organizations. Helgesen (1995) describes "ecological" leadership as having a concern for the group or the whole, thus the visualization of a web with the orb and radial lines creating more connection points. These points created a stronger bond for the group (or community) and encouraged a sense of inclusion (p. 49) that increased the likelihood of democratic participation.

Helgesen (1995) states that the web of inclusion is a perfect metaphor of how science affirms an explanation for our universe. She notes, "identity is inseparable from relationship" (Helgesen, p. 10). This dynamic connection and example of whole systems design was evident in many of the Seed to Supper learning gardens I examined. Most often one individual placed themselves at the center of the community. This individual had expertise and authority, but they also listened, facilitated and involved all members of the community in the process of building and managing the gardens. This behavior encouraged and fostered community building and sustainable leadership in the learning garden communities.

The concept of sustainable leadership is also consistent with Helgesen's web of inclusion theory. The patterns Helgesen (1990) identified in her early study were similar to sustainable leadership traits identified by Ferdig (2007) and Heifetz and 
Laurie (1997). These traits included helping others develop voice, access, open communication and networking as well as encouraging and providing opportunities to develop and practice leadership skills. And, as Ferdig (2007) writes, when leaders 'lead 'with' rather 'over' others in ways that account for the long-term viability of complex, interconnected systems" (p. 25). These patterns of inclusion, collaboration and networking led to community systems that supported local, sustainable community food security as demonstrated at many of the Seed to Supper sites.

The following internal and external partnerships shown in Figures $21 \& 22$ illustrate the range of partnerships operating at Brookplace and Forest Hills.

Figure 21. Integrated Partnerships: Brookplace

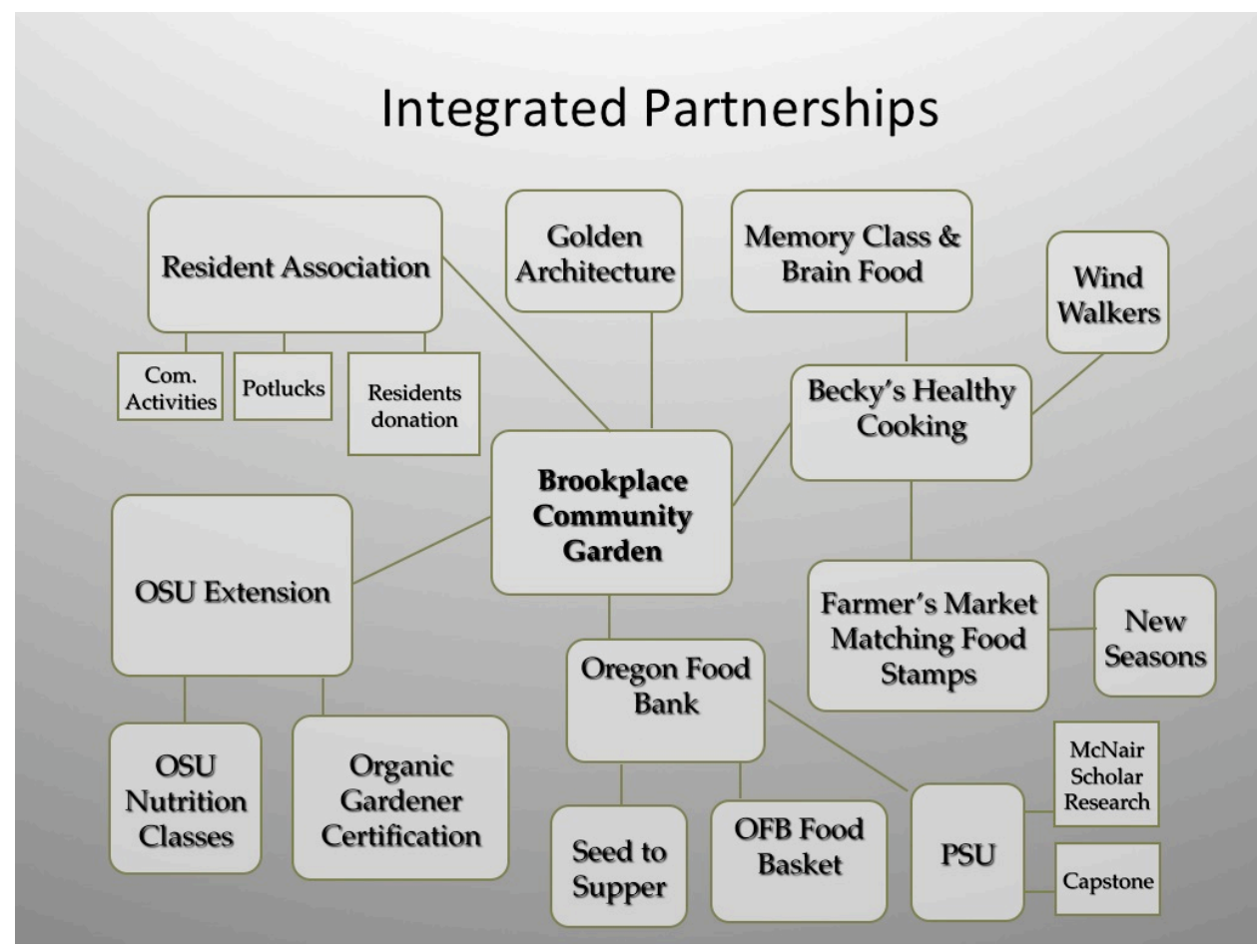


Figure 22. Integrated Partnerships: Forest Hills

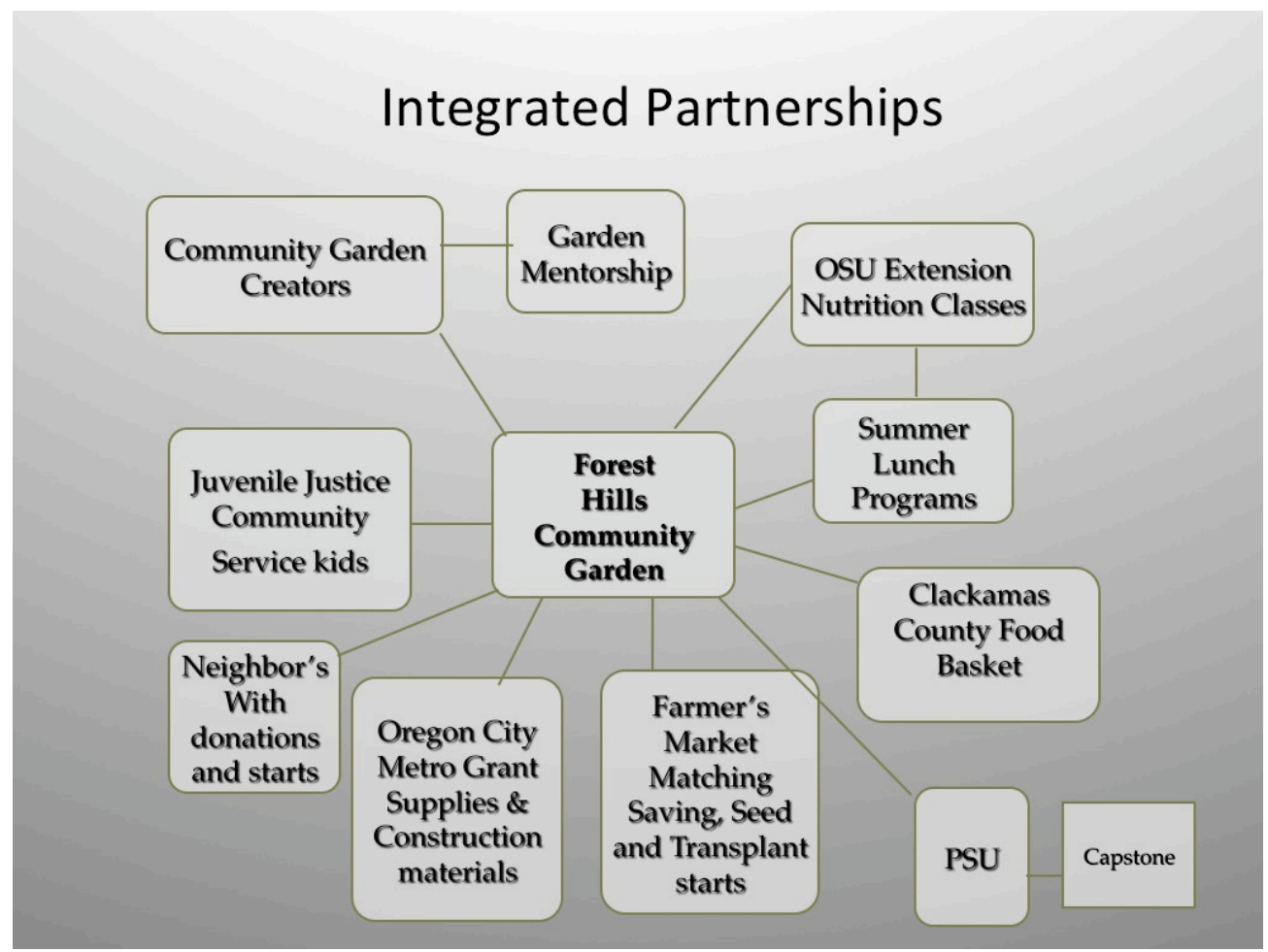

Helen, the on-site coordinator for both sites, with the help of a few key Seed to Supper participants and other community residents, coordinated the partnerships in Figure 21 and 22. These partnerships represent the integration of internal and external services contributing to the community food security of both these communities. The numbers and strength of these connections bring greater social capital to the gardeners and residents, thereby resulting in increased access to locally grown foods as well as empowerment for community members. This study points to the importance of integrated partnerships as essential tools for building local, sustainable community food systems.

The following section builds on the strengths of the webs and networks and introduces the implications and best practices that emerged from this study. It also 
includes recommendations to consider for long-term impacts on food insecurity, and lastly, suggestions for fostering citizenship through community activism and participation.

\section{Implications, Best Practices and Policy Change}

The main implications from this study are presented in the following order:

1) Programmatic best practices for sustainability and garden educators;

2) Barriers and policy recommendations for community leaders and the public service sector; and

3) Suggestions for fostering citizenship and creating pathways to food democracy and food justice through community activism and citizen participation.

This study found that these three areas are important to developing local, sustainable community food security.

The following best practices, recommendations and policy suggestions are based on interviews, surveys and on my observations, as well as my coursework in the Leadership for Sustainability Education program. And finally, some of the recommended practices reflect my own experiences as a community organizer and non-profit manager over the years. In most instances, I note the source of the recommendation/best practice. 


\section{1) Programmatic Best Practices for Educators, including Site Coordinators and Community Activists}

Community Building

Based on the findings from this study, a stronger sense of community developed when learning garden educators and site coordinators built integrated internal partnerships into learning garden program practices. Hinrichs (2007) states, "the issue of social inclusion in food system practice[s]... involving diverse stakeholders and participants can ensure multiple viewpoints and solidify the democratic foundations of practice" (p. 9). As Hinrichs' stated, the practice of inclusion in community building created opportunities for all participants or "stakeholders." Community building is therefore key to developing democratic food systems.

Best Practices for Community Building through Internal Partnerships

The following best practices stood out as important to community building. These best practices are divided into several categories: experiential learning, learner empowerment and food literacy.

Experiential Learning: Recommendations

Educators define experiential learning as a process where learners construct knowledge, skills and value from direct experiences (Subramaniam, 2002; Gaylie, 2009). Often situated both indoors and outdoors several of the Seed to supper sites combined hands-on learning with classroom discussion centered around a powerpoint presentation. Participants commented that hands-on participation proved most useful for their learning needs. 
a. Practice garden-based learning through hands-on learning techniques and experiential learning methods such as starting a class in the garden with a demonstration, then moving into the classroom setting. (As practiced at Riverside court.)

b. Organize garden work parties to encourage and build personal relationships in the garden. (Most of the Seed to Supper sites practiced work parties.)

c. Promote garden clubs as a way to contribute to an engaged educational community.

d. Develop a cookbook of participants' recipes and a recipe-sharing program. (Many small communities develop cookbooks for fundraising and community building. My experience with this took place in Sisters, Oregon during the 1980s.)

e. Organize special events to celebrate community within the garden space. Organize food sharing through coordination of the following activities: potlucks, eating locally grown food from the garden, harvest events and contests, such as baking, specialty foods, and making seasonal recipes, (i.e. pickling or preserving foods).

In addition to experiential learning methods, best practices for community building through internal partnership include developing learner empowerment and food literacy. Many of the Seed to Supper site coordinators and instructors used these practices to plan and implement garden programming in place-based settings. Seed to Supper participants shared stories about their improved self-reliance and 
confidence from their experiences in the workshops and classes. They also felt empowered by their increased food literacy and they wanted to share their knowledge with others by teaching and facilitating community food security. Learner empowerment led to sustainable leadership practices, increased resiliency, volunteerism and community relatedness.

Many of the following practices in the Seed to Supper program, are suggestions and recommendations from the participants, instructors, on-site coordinators and community leaders. The following best practices focus on planning and developing curriculum and community activities to enhance learner empowerment and food literacy.

Learner Empowerment and Food Literacy in the Garden Education Curriculum: Recommendations

The Seed to Supper program teaches food literacy through garden-based handson learning that leads to greater learner empowerment. These practices enhance learner involvement and participation.

a. Teach garden-based learning by including hands-on experiences combined with classroom discussion and visual materials, including hand-outs and PowerPoint presentations. This is a standard practice for Seed to Supper classes and workshops. Learners benefited from visual aids and discussions about the garden-based lesson plans, combined with hands-on learning. 
b. Consider beginning classes with a meal or garden snack. Growing and eating food from the garden may enhance confidence and create a stronger relationship to foods and greater food literacy.

c. Teach complex gardening skills such as composting, vermiculture, permaculture, organic gardening, sustainable gardening practices, planting from seed, harvesting seeds. Teach no-plow methods and lasagna gardening or sheet mulching for seniors to lessen weeding and bending over. These practices enhance practical knowledge and help to build confidence.

d. Build peer-to-peer teaching and learning into curriculum activities for empowering learners to demonstrate new knowledge and pre-existing knowledge.

e. Incorporate feedback loops through evaluation processes including surveys, interviews and other assessments tools for all activities. These kinds of feedback loops contribute to the knowledge base for curriculum development and teacher training.

Instructor training for Enhancing Learner Empowerment: Recommendations

In addition to teaching methods, communication and leadership practices were found to contribute to the successes of the Seed to Supper program. The practices listed below can enhance teacher in-service training by building stronger communication and sustainability leadership models that lead to greater learner empowerment and participation. 
a. Design instructor training in relationship to populations. Seed to Supper has a diversity-training model that introduces instructors to tolerance and open communication models for teaching. These models reflect some of the indicators found in the web of inclusion.

b. Encourage responsive teaching methods through teacher training activities that model adaptive teaching practices. These responsive teaching methods include adapting the lesson plan to the specific learning situation.

c. Encourage use of the motto: right plant, right place and adapt right instructor or mentor to right place... pair up through careful selection and pairing up with communities using assessment tools, inventories, interviews and presite visits. This can be encouraged in trainings for instructors and site coordinators as well. The Seed to Supper instructors self-select to teach at sites they are interested in, a practice that ensures interest and motivation for success.

d. Practice and teach step-back, step-up methods allowing others to have an opportunity to demonstrate knowledge, leadership and change. Many of the teaching practices suggested here prepare garden-based instructors for empowering and fostering learner empowerment for adult learners. Ferdig (2007) states that leaders who practiced sustainable leadership models often created environments that led people/participants to generate and explore their own answers to challenges faced. "Instead of giving directions, sustainability leaders develop and implement actions in collaboration with others, .... [by 
integrating a] framework that provides clear accountability, and enough flexibility." [This] fueled new thinking and innovations" (Ferdig, 2007, p. 32). Ferdig's description is consistent with the following best practices found in the web of inclusion organizational model at the Seed to Supper sites.

All of these recommendations focus on internal partnerships for encouraging community building through experiential learning, learner empowerment and food literacy. Now, we turn to external partnerships.

Best Practices for Community Building through External Partnerships As important as internal partnerships are, external partnerships can profoundly impact learning garden programs by building resources and opportunities for participants. Garden educators and site coordinators can develop external partnerships to increase access to resources and to create opportunities to support, encourage and foster access to food. Through celebrating, sharing and building community, the following best practices build on external partnerships by employing networking and community development practices, mentorship for sustainable leadership practices and community education and community celebration.

Networking and Community Development: Recommendations Building networks and relationships contributes to community building that is consistent with the concept of the "web of inclusion" (Helgesen, 1995). This inclusion of community players created a network of relationships as illustrated in Figure 20. In the learning garden programs, these external partnerships also 
contributed to increased access to locally grown foods as well as opportunity for mentoring leadership. The following recommendations are for educators, including site coordinators and community activists for enhancing external partnerships.

a. Develop community resources through networking with local, state and federal agencies, groups, collectives, state extension services, etc.

b. Use development tools such as grant writing, fundraising and community/business sponsorships and in-kind donations.

c. Delegate development activities to internal players, (i.e., key participants in the learning garden programs that show an interest in developing an idea such as a class or fieldtrips). Brookplace has an example of this practice.

d. Develop local resources: soil, supplies, seeds, capital improvements, land/space, containers, plants, and produce. All the Seed to Supper sites developed additional resources through partnerships with the business community and with local government grants.

External partnerships through these practices are critical for building community development opportunities for food insecure communities. Involving participants in these development practices provides additional learner empowerment. The following section focuses on mentorship as it relates to development and leadership opportunities.

Mentorship for Sustainable Leadership: Recommendations Mentorship provides opportunity for sustainable leadership—-these mentoring opportunities build on existing skills and knowledge within food 
insecure populations. Successful community building relies on the all the integrated partnerships recommended in the preceding section. To order to ensure successful mentorship there are many aspects of sustainable leadership to consider. Knowles, a humanist educator, has written that adult learners are self-directed and often, independent learners (Elias \& Merriam, 2005). With this in mind these recommendations to community organizers, instructors and coordinators and are offered in the spirit of developing learner empowerment through sustainable leadership and mentoring.

a. Delegate organizational tasks to key community participants. This practice took place at all of the Seed to Supper sites.

b. Utilize Master Gardeners for mentoring to build expertise and develop gardening mentors within the community. This idea was suggested by most the participants, all of the Seed to Supper instructors and the community leaders.

c. Create an "adopt-a-community garden mentor program" where garden instructors teach in the community and return throughout a season to provide continued support in a mentoring capacity. In addition to mentoring, it was important to encourage sustainable leadership development as well as skills for garden-based learning. The following best practices help to build a receptive environment for sustainable leadership. Sustainable leadership practices ensure the inclusion of food insecure populations and lead to strong community development and buy-in from community members. 
Mentoring sets the stage for next set of recommendations for practicing sustainable leadership.

Best Practices for Encouraging Sustainable Leadership

a. Build human resources from within community through volunteerism and leadership roles. Brookplace used this model for gardening events.

b. Create opportunities for volunteerism, i.e. harvesting, watering, grant writing, teaching, skills building, mentoring and other creative activities.

c. Foster open forms of communication in classes and for community organizing --practice active listening.

d. Encourage trust, commitment, and responsibility.

e. Promote TEK (Traditional Ecological Knowledge) (Nelson, 2008). Many forms of TEK exist in the communities studied—at Brookplace this was demonstrated through the diversity of plantings, and planting designs found in the gardens.

f. Create safe places for learning and community building.

g. Reward and practice gratitude and appreciation.

h. Practice adaptive management practices (Senge, 1990). This is a simple suggestion, which implies flexibility and a receptive attitude when resolving unexpected events and situations.

i. Practice tolerance. The Seed to Supper program encourages cultural diversity and inclusivity. This can be challenging for some sites, and diversity training for instructors is helpful. 
j. Build reflection into all activities through discussion, journaling and other forms of reflection.

When these practices were applied at the Seed to Supper sites, they led to greater local, sustainable community food security as evidenced at Brookplace and Riverside Court. In the guidelines of the Community Food Security Coalition, 2012 they assert that: "Community food security projects seek to engage community residents in all phases of project planning, implementation, and evaluation" (2012). This study found that when community members became active leaders in learning garden activities, their food literacy increased, self-reliance improved and the community as a whole gained social capital.

\section{Community Education}

This section continues recommendations for building external partnerships and focuses on the role of community education and celebration of community. All of the Seed to Supper sites in this study encouraged community education to build skills and opportunities to share leadership roles—often taught by outside teachers, including Seed to Supper instructors. Flores (2006) and Goldbard (2006) have both written about the impact of bringing teachers, artists and community organizers into community setting to develop cultural activities. In this study, the site coordinators and instructors would engage garden educators into communities to increase gardening skills and knowledge. These educational activities contributed to a greater sense of community and learning for people within the scope of place. Community education becomes enriching for individuals as well as for the 
community (Flores, 2006; Goldbard, 2006). The following recommendations foster educational opportunities for garden-based learning programs for food insecure communities. Many of the Seed to Supper sites practiced these recommendations.

a. Promote educational opportunities such as garden classes by bringing outside expertise into the community through continuing skills development.

b. Promote educational workshops to provide inspiration and community morale.

c. Collaborate with other educational institutions such as university capstone courses to build collaborative partnerships integrating different levels of partners.

(a. through c. were practiced at all of the Seed to Supper sites.) Networking and community building, mentorship and community education practices all led to engaged Seed to Supper communities - the participants valued learning through networking with external partners and mentorship contributed to the morale. The last section which focuses on building external partnerships looks at the role of community events and how celebration helps facilitate the goals of garden-based learning by building community through a web of inclusion.

Community Events

Building community through partnerships was also a common thread at each of the Seed to Supper sites. Community building through celebration, sharing and organizing has been identified in numerous disciplines as an effective way to create social capital (Goldbard, 2006; Borrup, 2006). Borrup (2006) has written a guide 
for community organizers advocating for the building of and transformation of community through local assets including the arts and culture. As a member of the "Partners for Livable Communities," his guidebook focuses on celebratory events to build stronger social fiber to community setting. The following recommendations reflect many of Goldbard's and Borrup's ideas for celebrating community.

The following community building activities are examples of celebratory events found in the Seed to Supper sites for bring community partners together to share networking efforts:

a. Health Fairs: Bring in outside expertise to share healthy community practices, and creates access to outside resources and knowledge.

b. Food Fairs: Provide an opportunity for sharing the wealth and surplus within the community.

c. Farmer's/Gardener's markets, provide economic opportunity and exchange or bartering opportunities for small neighborhoods. In Portland, the Cully neighborhood has started a farmer's market in a food desert region and is the appropriate scale for the neighborhood it serves.

d. Fix-it Fairs: Informational fairs are organized for easier access to knowledge. These kinds of fairs are empowering for do-it-yourself populations as well as encourage community projects. This fair helps to build self-reliance and community viability. The "Fix-It Fair" is organized and presented by the City of Portland Bureau of Planning and Sustainability and is in its $26^{\text {th }}$ year of 
serving Portland neighborhoods. The Seed to Supper program has offered gardening workshops at the Fix It Fairs for many years.

These celebratory practices and recommendations for community building were found at most of the Seed to Supper sites, and in other learning garden programs as well. Combining educational community events with celebration activities demonstrated the integrated partnerships demonstrated at the sites created a community forum to share food literacy, learner empowerment and the benefits of community building.

This section ends the discussion about best practices using internal and external partnerships. The next section continues to examine programmatic best practices for learning garden curriculum development. It does so by using placebased and whole systems design practices building on the previous section on partnerships and the leadership aspects of the web of inclusion.

\section{1) Programmatic Best Practices for Educators, including Site Coordinators and Community Activists for Garden-based Program and Curriculum Design}

Place-based learning

Place-based learning practices and approaches offer learning in the context of where people live. In addition, these practices have the potential to increase access to locally grown food within the context of place for food insecure populations. Williams \& Brown (2012), using Gruenewald's definition of placebased learning (2003), explain that: "place includes not only the physical landscape and ecology where students live, but also the cultural and socioeconomic 
communities that live within that landscape" (p. 64). It is in this context that the Seed to Supper curriculum serves food insecure populations because the classes take place in the communities where participants live and interact with garden education. Thus, Seed to Supper instructors can respond to the immediate concerns of learners.

The findings of this study also indicated a solutions-based approach to access local foods through community building, learner empowerment, sustainability leadership and food literacy within the context of place-based learning. This approach blends place-based practices and experiential learning and considers human relationships. Sobel (2004) writes "the history, folk culture, social problems, economic, and aesthetics of the community and its environment are all on the agenda" (p. 9). Sobel considers the preceding cultural elements as essential considerations for place-based learning. Sobel (2004) promotes a creative and responsive learning environment. To further augment the discussion, Knapp (2005) describes the important elements found in place-based curriculum as including the surroundings as the foundation for curriculum development with an emphasis on learners helping to create knowledge (as opposed to being consumers of knowledge). Learners' questions and concerns play a central role in what is studied and teachers participate as co-learners to help develop community resources and possibilities (Knapp, 2005). Additionally, Woodhouse and Knapp (2000) identified the place-based curriculum content as multidisciplinary, integrating self, other, and place and including ecological, economic, multigenerational and multicultural 
aspects. The following are best practices for curriculum development using whole systems design. As described by Knapp (2005), the following steps integrate placebased learning methodologies through observation of the learning communities.

Recommendations for implementation

Steps one through three use whole systems design strategies for best practices in developing curriculum and program designs for garden-based education. These design practices are based on my observations of the Seed to Supper program. Sustainable practices in designing educational programming within the context of place-based learning and experiential learning practices encompass whole design thinking and ecological design. Edwards (2005) has asserted that the "integration of sustainability and community requires a systems perspective focused on relationships among numerous stakeholders" (p. 29). When designing curricula, consider the following sustainability and solutions-based practices.

Step 1) First, practice observation to develop a solutions-based response. Listen to what learners say about the needs of their community. Here are a few questions to ask: What knowledge is pre-existing in the community that can be incorporated into the learning process? How can programs encourage exchange of knowledge and foster intergenerational and cultural diversity? The following recommendations foster observations and a solutions-based to response to curriculum design. 
a. Ask questions about the existing knowledge base, to build a foundation for curriculum development based on learner's needs.

b. Create opportunities for shared learning through open communications, public gathering in central locations.

c. Provide alternatives for place-based issues or needs. For example, if there is no space to garden - teach container gardening or access public gardens willing to contribute space or produce.

d. Overcome language barriers by providing language interpreters, creating signage for space, and providing resource materials in languages spoken. Brookplace is an example of how language barriers could be addressed. The capstone class provided composting instructions in both Russian and English languages.

Step 2) Create a vision and identify needs for the communities/populations. Cultural relevancy and interactions within the community will help promote placebased solutions for curriculum and program activities. Consider the strengths and weaknesses of the community's learning needs. Identify these needs within the context of urban vs. rural or suburban settings. Other things to consider are: the type of community, (i.e. community center vs. a housing complex) and the special circumstances involved in these settings. These recommendations contribute to whole systems design for garden-based curriculum and programmatic planning.

a. Create assessment tools, surveys, and questionnaires to evaluate needs, curriculum and feedback on existing programming or future programming. 
b. Develop tools using what is located on the site or in the community, for example fences for trellising plants, balconies exposed to sun for container gardening, raised beds for physical disabilities or the needs of depleted soils.

c. Ask what the location/place offers in terms of existing resources, it may be as simple as lots of sunshine, or a large community building. (Similar to b., but more generalized.)

d. Discover what limitations can be turned into opportunities.

e. Develop strategies to overcome perceived limitations, (i.e., lack of running water to a garden site, lack of a classroom space, or low funds or resources). Step 3) Using whole systems design practices described in steps $1 \& 2$, build a curriculum from the observation/visioning process. This process will build the content for learning curricula and learning activities based on the needs of the learning environment. Step 3 develops a curriculum using the existing community culture. Garden-based education can focus on food histories and food production capabilities, such as food preservation and other techniques, guerilla gardening, harvesting, subsistence farming, cottage industries, engineering, etc. Brookplace had a wealth of expertise and many participants had designed unique gardens using materials found in their community. The following recommendations are practices to consider when developing curriculum for garden-based programming within a place-based approach.

a. Access pre-existing knowledge by encouraging interaction among community members. All the Seed to Supper sites practiced and encouraged 
interaction among community members. Often these activities happened in the garden or in communal areas of the housing projects and community centers.

b. Create assessment of community members--this could be organized as a speaker's bureau.

c. Create teaching opportunities for participants. Brookplace had the best opportunities for participants' to teach.

d. Allow for information exchanges and build on preexisting garden knowledge and practices, this is related to a. \& b. but focuses specifically on gardening skills.

e. Design curriculum options for the population's capacity, i.e. children, adults, language barriers, physical and mental barriers.

f. Design for indoor/outdoor learning within the context of place.

g. Consider the time constraints of participants when designing activities.

h. Consider long-term impact on community, i.e. maintenance, upkeep, harvesting, seasonal needs and impact on program. Plan for seasonal, yearto-year programming at the same location—consider phases for curriculum topics. For instance, in year-one, teach garden planning, year-two add a unit on cane fruits and canning, year-three add winter gardening. These programmatic recommendations are suggestions that emerged during the process of this study. This ends the section on programmatic best practices for building community through integrated internal and external partnerships using 
experiential learning, learner empowerment, food literacy, networking, mentorship and sustainable leadership in a place-based community approach. The next section focuses on the barriers and recommendations for policy changes to help implement and support the preceding practices through addressing the major barriers to food security.

\section{2) Barriers and Policy Recommendations for Community Leaders and the Public Service Sector}

In addition to the programmatic best practices for educators, site coordinators and community activists, the results from this study indicate the need for policy changes in local, state and federal government. Contrary to what some leading experts have said, food insecure populations value local, nutritious fruits and vegetables (Heffter, 2011). The recent "Got Green" survey found by a 2-1 margin that "healthy foods" were a priority for low-income women of color, but the "high cost of fresh and organic fruit and vegetables and the lack of grocery stores made feeding their family a healthier diet too hard" (Heffter, 2011, p. 1). Similarly, the barriers identified in this study pointed to a lack of access to fresh local foods. Additionally, processed and corporate foods are cheaper and easier to access (Winne, 2008). The barriers discussed point to the difficulty food insecure populations face in accessing locally, grown foods and each is followed by the recommendations for policy changes that can help remediate these issues. These policy recommendations are derived from the interviews with Seed to Supper instructors, site coordinators and community leaders as well as from my own 
observations. Note that Portland has already adopted many of these practices, however, there is still a need to disseminate information about what is available in terms of local resources to access local foods.

\section{Cost}

This study showed the high cost of locally, grown fresh foods was the number one reason for lack of access as well as the cost for gardening inputs including soil, seeds, and soil amendments and fertilizers. Mougeot (2006) states, Municipal governments should start with the right question and ask, "What can urban agriculture do for my city (not what can my city do for it)?" (p. 62). He asserts that when we look closely at urban agriculture, many cities already support many of these types of activities. He points to composting and community gardens as examples that many cities have developed because they view it "as tool to address multiple challenges faced by the city, its environment, its economy, and its people" (p. 62). Mougeot suggests that the more "players" involved (integrated partnerships) with urban agriculture, the more robust the outcomes and longer lived these endeavors will be. He adds that this inclusive approach creates public policy that is "more comprehensible, durable and consistent" (p. 62). The following recommendations start with local change and end with federal and national changes needed to support greater access to locally grown foods for food insecure populations. 
Recommendations for Policy change to Reduce the Cost Barriers Local (City, County and State) levels.

The cost of locally grown foods was the number one barrier according to the Seed to Supper survey and interview results. These recommendations are referred to policy makers as tools for change and for fostering greater food security for the communities examined in this study.

a. Create a subsidy system for local farmers in order to create affordable local foods.

b. Redirect surplus local foods to local food banks and pantries.

c. Support local farmers at the peri-urban fringe by providing greater access to urban consumers.

d. Develop greater access to gleaning programs for food insecure populations (Portland has several models for this activity).

e. Support the development of partnerships (as mentioned under community building on p. 10) to provide resources for gardening activities in food insecure communities. This could be achieved through incentives for partnerships.

f. Expand distribution networks for local foods programs through mobile farmer's markets or, as in Bend, Oregon's Feed the Need, a mobile refrigerated unit, which delivers surplus foods to food insecure neighborhoods. This is a sustainable practice rescuing millions pounds of food from the waste stream. 
g. Place building moratoriums on fast food and unhealthy food outlets in disadvantaged areas - food deserts.

h. Promote edible landscapes through public and private education programs (Nordahl, 2009; Flores, 2006; Mougeot, 2006).

i. Expand garden-education programs such as the Seed to Supper and Growing Gardens programs. Growing gardens mentors families one-on-one for a full gardening season to insure access to gardening expertise and food literacy. These programs can have a direct impact on food insecure populations. All of these recommendations for local policies can foster greater food security for all populations and set the stage for the following federal policy recommendations.

Recommendations for Policy Change to Increase Access to Fresh Foods Federal level

The following recommendations propose a cultural food shift for policymakers that has the potential to create pathways to greater food security for local, sustainable food systems. The literature promotes these activities and recommendations with national food security as a central theme (Pollan, 2008; Winne, 2008).

a. Increase and promote awareness of, and increase incentives, for food stamp/SNAP use at local farmer's markets, fruit stands and Community Supported Agriculture.

b. Support local, state and federal economic incentives for urban agriculture reform. 
c. Create large-scale local food policy on local, state, and federal level to leverage funding for urban agriculture, and education reform to support lowcost nutritious foods. The city of Portland's and Multnomah County formed a food policy council in 2002; this model has received national recognition (Nordahl, 2009; Winne, 2008).

d. Subsidize organic and local agriculture through reform of the federal farm bill legislation.

Although many of these policy recommendations are not new or original ideas, they provide pathways to greater local access to fresh foods for food insecure communities and potentially could lead to greater local, sustainable community food security. All of these recommendations were discussed in the interview process with Seed to Supper participants, instructors and community leaders including elected officials. The implications of this study suggest that when participants are empowered by learning garden programs, they become supporters for better public policy concerning food security. These policies support local engaged community food systems.

Garden Space as a Barrier

Access to garden space ranked second to cost as a barrier to food security in this study. This major barrier has prompted creative programmatic responses such container gardening, yard sharing and other community garden programs such as Seed to Supper and other programs like Growing Gardens. Because of this, developing space within food insecure communities should be a top priority for 
policymakers. Gardening close to home increases access to locally grown foods. Researcher Nordahl, (2009) advocates that "public space permeates cities, giving them order and form, and is arguably every city's greatest, most extensive physical resource" (p. 136). In view of the abundance of viable soils in the Willamette Valley, this barrier should be easy to overcome. There is a need to legislate more public lands for civic, urban and public agriculture.

Nordahl (2009) points to the "misconceptions of traditional community gardens, because they are often regarded as the ultimate safety net for many of our food problems" (p. 88). He critiques the idealistic claims of "self-reliance through community gardening" and citing Winne, (community food security advocate) as admitting that these claims for greater "self-reliance" come close to "self-righteous pontificating" (p. 88). It is with this caution that the following recommendations for local, and nation-wide change are put forth. Although, Portland has over 40 community gardens with support from the city for water and space - many of these sites have waiting lists of up to five years. Additionally, the fees to participate and the costs to maintain the sites and the transportation to access these gardens come at a very high price to food insecure populations facing poverty and lack of basic needs.

Riverplace Court had access to several public gardens located throughout the Portland Metro region. This creative and proactive practice led to greater access to locally grown foods. (See Chapter 4 for photos of the City of Portland City Hall garden and the Multnomah County eco-roof building). The following 
recommendations represent a diverse array of solutions for lack of available garden space.

$$
\begin{aligned}
& \text { Recommendations for Policy Change for Expansion of available } \\
& \text { Garden Space }
\end{aligned}
$$

a. Create adaptive land-use policy to support use of unproductive, fallow land in both urban and rural settings.

b. Create greater access to public lands for gardening purposes - civic agriculture has been extolled for its positive impact in urban settings (Nordahl, 2009).

c. Promote yard sharing through neighborhood organizations.

d. Promote polyculture practices in urban and rural farming and gardening techniques (Mollison, 1988; Hemenway, 2009; Holmgren, 2002).

e. Encourage and develop incentives for public community garden spaces for use by food insecure populations (e.g., Portland City Hall garden).

f. Create public funding for community gardens in all affordable housing projects - i.e. a program similar to the $1 \%$ for the arts program in Oregon. All state buildings have $1 \%$ set aside for art. Perhaps a $1 \%$ for local, sustainable community gardens.

g. Provide more subsidies to support families that want access to community garden plots in order to offset fees charged for the privilege to garden in a PPR community. 
Many of these practices provide practical place-based solutions for the barrier of access to garden space. These policies and recommendations offer many benefits to food insecure communities served by learning garden programs. Portland has taken steps through its food policy council to map available land (The Diggable City Project) for urban agriculture. Continuing this trend to support greater food security for Seed to Supper populations is important for food insecure populations. This study explored the benefits of creative land use policies and their impact on access to locally grown foods.

Transportation

Due to a lack of transportation options and limited financial resources many food insecure populations lack access to grocery stores, community gardens, fruit stands and farmer's markets. Often the lack of public transportation limited access to affordable, fresh locally-grown foods, especially among physically handicapped and large families. This barrier had a direct impact on where people shopped for food. Many of the following ideas and suggestions were shared in the interviews with Seed to Supper participants and instructors, site coordinators and community members.

Best practices and Recommendations for Overcoming Transportation Barriers

Transportation is a critical barrier that needs to be overcome in order to improve access to locally grown foods. Many of the recommendations included in 
the next section have proven successful in other regions, programs and municipalities (Winne, 2008; Nordahl, 2009).

a. Commit to and develop more affordable public transportation options. One example may be to develop special field trips to markets, fruit stands, farmer's markets using chartered buses sponsored by municipals including city, county and state.

$b$. Create mobile gardening, kitchen, and sustainable education units that bring services, produce and resources to food insecure communities.

c. Create more carpooling opportunities for food insecure populations. Many of the residents at Brookplace were using this option for various activities.

d. Subsidize transportation for food insecure populations - bus tickets to access farmer's markets, CSAs, and educational opportunities .

e. Create mobile food pantries utilizing a refrigerated van with capacity for a kitchen, and food storage. This kind of project appeals to non-governmental agencies, corporate sponsorship and private foundations, because of the visibility of mobile units.

f. Locate community garden opportunities close to people by placing them in their yards, in their schools, in their workplaces in order to lessen the dependency on transportation systems. The Learning Garden Laboratory located in southeast Portland is a good example of a neighborhood gardening "village" site that is fully integrated into the middle school program, the Portland Parks and Recreation program, the OSU master gardener's program 
and PSU's Leadership in Sustainability program (Skinner \& Chi, et. al., 2011). By placing a comprehensive community garden education program like the Learning Garden Laboratory into a complex integrated partnership system, it stands to survive the whims of funding and economic hardship. Additionally the transportation issues are eased through proximity to the middle school and a public park.

Transportation is a major barrier for food insecure populations. With more creative programming within local communities and neighborhoods, there are options to improve this barrier, however, public transportation as a basic infrastructure issue for regions is imperative for building access to fresh locally grown foods. Portland has taken steps to develop an equitable public transit system - however with economic hardship we are witnessing cut backs to frequency of services, loss of fareless regions, and fare increases for services. These budgetreducing practices impact food insecure populations and create barriers to locally grown foods.

Economic Hardship

Economic hardship is the main barrier contributing to food insecurity. In order to build local, sustainable community food security community partners and local, state and federal governments need to advocate for greater economic parity. Oregon Food Bank has a strong advocacy program and is a national model for fighting hunger at it root causes (Winne, 2008). Many food justice practitioners point to the need to develop a stronger "rights-based food system" (Anderson, 2008, 
p. 593). When food banks take on advocacy and programming that helps to empower participants through rights-based programming, learning garden programs like the Seed to Supper program may indeed impact economic hardship. The findings of this study showed that learning gardens can act as a democratic space that empowers participants and helps them through community engagement and learner empowerment. The following section suggests ways to foster citizenship and create pathways to food democracy and food justice.

Citizenship: Pathways to Food Democracy and Food Justice: Implications for Activism: Action and Participation.

Activism, action, and participation in local sustainable community food systems provide opportunities to promote food democracy and food justice. As food insecure communities develop both human and capital resources through community development, and greater citizen participation, the result is often greater economic advantage. However, this economic advantage may look different from how we usually think of economic advantage. An important objective for many populations is simply having access to enough culturally appropriate foods. Hinrichs (2007) stresses the importance of food and its symbolic meaning for society at large. She states the following in "Practice and place in remaking the food system":

Having both material presence and symbolic charge, food now figures prominently in struggles for power, negotiations about policy, possibilities for partnership, and new and renewed expressions of pleasure and identity. 
Consequently, food provides a unique analytical and experiential nexus, drawing together and crystallizing many urgent, complicated problems facing society. No longer taken for granted or viewed in isolation food can and should be connected to community vitality, cultural survival, economic development, social justice, environmental quality, ecological integrity, and human health (Hinrichs, 2007, p. 1).

Hinrichs (2007) has captured the power and importance of food to healthy culture-making and community health. In "remaking" our food system, (I would add to this re-discovering our food system), the following food advocates have led the food movement to include activism and greater community participation. These researchers, advocates and leaders have paved a path that gives all citizens a chance to participate in the remaking of our food systems.

Shiva (2005), Sen (1999), Gottleib \& Joshi (2010) and the founders of the concept of community food security - Fisher, Winne, and Joseph, have all postulated that the rights of people to access fresh, locally grown foods and the economic parity to do so are paramount to food security. Perhaps, Nobel economics prize winner, Amartya Sen (1999) offers the broadest vantage point in his book, "Development as Freedom," providing us with a direction to follow. His theory places individual freedom as central to the analysis of a globalized economy and posits a "paradigmshifting" approach, which considers the implications of current development practices. Sen advocates for "the removal of major sources of unfreedom: poverty as well as tyranny, poor economic opportunities as well as systematic social 
deprivation, neglect of public facilities as well intolerance or over activity of repressive states" (p. 3). Sen (1999) questions development as an economic cureall, stating that, "the contemporary world has denied elementary freedoms to vast numbers-perhaps even the majority-- of people... [and] relates directly to economic poverty," robbing them of the ability to satisfy hunger or to achieve adequate nutrition (p. 4). With this broad charge regarding the need to solve the current economic disparity in today's globalized economy, I suggest that we follow the many who have led the charge before us and incorporate basic components of activism and grassroots organizing into the programs that impact food insecure populations.

By using rights-based food systems that connect the local and sustainable with transparency and inclusiveness, and food as a human right (Anderson, 2008), programs such as the Seed to Supper are positioned to contribute to overcoming economic inequity. With concepts similar to a rights-based food system, Gottleib and Joshi (2010) postulate a "broad conceptual framework" (p. 5) for considering how food justice advocates guide policy change for our food systems. They state the importance of "the how and why and what we eat" as critical to the new concept of food justice. "Food Justice" as a concept attempts to deal with the core issues of equity, empowerment and social change in our food systems (Gottleib \& Joshi, 2010). They point to the need to create "the expansion and linkage of groups and issues" that help bring about changes to our food system through more just 
"political action, economic change [and] the restructuring of global, national and community pathways" (Gottleib \& Joshi, 2010, p. 5).

This community and rights-based approach is related to many of the best practices discovered by this study. By employing a solutions-based activism, along with sustainability practices espoused by whole systems design along with encouraging participation through sustainability leadership models, learning garden programs may contribute to food democracy and food justice.

In the course of this study, I have discovered some of the barriers to locally grown foods and I have found that a powerful social drama plays out in the learning garden (Withers, 2010). The Seed to Supper sites Brookplace, Forest Hills, Riverside Court, Cascade Views and Lakeview Correctional Facility have increased community participation in their local community food systems. Each of these sites is unique in its approach and at varying points along the continuum towards attaining community food security. However there are lessons to learn from these communities. I found that many of these communities' inclusive social systems practiced community building in order to build internal and external infrastructure that supported greater food security. Sustainable leadership practices and whole systems design provided greater access to success for the learning garden programs. I also discovered that the concept of the web of inclusion can be applied to programs assisting marginalized populations because it provides a safe place for garden-based learning to foster access to locally grown foods, within place-based teaching approaches and community building solutions. 
I found that learning garden programs that utilized comprehensive gardenbased curricula and practices improve access to locally grown foods and include and empower food insecure communities. This study also pointed to the importance of utilizing sustainable leadership practices to encourage and support learner empowerment, and increased food literacy. Much of the success of the Seed to Supper program is based on experiential teaching methods combined with community building methods. Lastly, many of these recommendations can be readily applied to garden-based learning programs that are place-based as in the Seed to Supper program.

\section{Benefits of Community-Based Research}

As a student researcher, my involvement in this community-based learning project gave me first-hand experience in a partnership that integrated the research sites and the academy, demonstrating the impact of community partnerships and research. This research project provided me the opportunity to conduct real-world, practical and applied research. The benefits of community-based learning and practices are numerous, but the greatest value lies in the positive impact on the communities we reside in and the opportunity for scholarly discourse.

As Minkler (2005) identified in her community-based participatory research, using an inclusive approach helped address the complexity of urban health problems (p. ii3). Rather than bringing in outside experts to create social change, she advocates for locally placed or "community-based" partnerships for communitybased participatory research to create social change. 
My role as researcher in a community-based setting has added a unique layer of involvement to this research process. By becoming a Seed to Supper volunteer, I became a partner with the Oregon Food Bank and the research sites where I volunteered. The community partner, Oregon Food Bank, along with the learning garden sites served as co-creators of the project surveys and the interview protocols. More recently, I am contributing to the curriculum redesign for the Seed to Supper program. I collaborated with key community members and participants by making presentations about this study at seminars, information sessions and for Seed to Supper trainings. During the last summer of the data collection, I attended many of the senior capstone classes and assisted the sites to develop and build community compost systems. My role was mainly to facilitate, observe and answer questions from both the capstone students and the Seed to Supper participants.

Community-based learning provided a meaningful and engaged research process for both the researcher and the community program, which builds on the several of the concepts discovered in this study; including place-based solutions and inclusion, and ultimately, provided an experiential learning process. The circular nature of the web of inclusion is an ideal metaphor to describe the process of community-based research.

\section{Conclusion}

This chapter lays out options for addressing the ongoing need to build local, sustainable community food security. The key implications of this study identified that community building, learner empowerment through place-based learning 
methods, and providing opportunities for sustainability leadership through the web of inclusion, all contributed to increased access to locally grown foods and successfully empowered food insecure people and their communities. The web of inclusion weaves an interrelated system of internal and external community partnerships that enhance to learner empowerment and food literacy. This inclusion fosters greater participation in citizenship and contributes to food democracy and food justice within the communities examined in this study.

In order to move beyond the limitations of this study I recommend additional research on learning gardens programs over an extended period of time. This examination should include other learning garden programs in order to compare data collected from a larger sample group for comparison. A long-term study would increase the validity and add to the body of evidence-based research showing the impact of garden-based learning on food insecure communities.

Although the scope of this study focuses on the impact of learning garden programs on food insecure populations, the importance of empowering citizens to mobilize local food security has broader implications. As a society, it is imperative that we meet the challenge of creating healthy communities by engaging local community food systems through learning garden programs for all citizens. 


\section{REFERENCES}

Abi-Nader, J., Ayson, A., Harris, K., Kerrera, H., Eddins, D., Habib, D., \& Villanueva, L. (2009). Whole measures for community food systems: Values-based planning and evaluation. Vermont: Center for Whole Communities.

Anderson, M. D. (2008). Rights-based food systems and the goals of food systems reform. Agriculture and Human Values. 25, 593-608. DOI 10.1007/s10460008-9151-z.

Anderson, M. D., \& Cook, J. T. (1998). Community food security: Practice in need of theory? Agriculture and Human Values. 16, 141-150.

Bailey, C. A. (2007). A guide to qualitative field research $2^{\text {nd }}$ ed. Thousand Oaks, CA: Pine Forge Press.

Barndt, D. (2008, 2002). Tangled routes: Women, work, and globalization on the tomato trail. Lanham, MD: Rowman \& Littlefield.

Belasco, W. J. (2007). Appetite for Change: How the Counterculture Took On the Food Industry, 2nd ed. Ithaca, NY: Cornell University Press.

Bernard, H. R. (2000). Social research methods: Qualitative and quantitative approaches. Thousand Oaks, CA: Sage.

Bolman, L. G., \& Deal, T. E. (2008). Reframing organizations: Artistry, choice and leadership. San Francisco, CA: Jossey-Bass.

Borrup, T. (2006). The creative community builder's handbook: How to transform communities using local assets, arts, and culture. Saint Paul, Minnesota: Fieldstone Alliance.

Bryant, A., \& Charmaz, K. (2007). The Sage handbook of grounded theory. Thousand Oaks, CA: Sage.

Capra, F. (1996). The web of life: A new scientific understanding of living systems. New York: Anchor Books.

Capra, F. (2002). The hidden connections: A science for sustainable living. New York: Anchor Books.

Center for agroecology \& sustainable food systems website. CASFS. (2011). About CASFS. Retrieved from: http://casfs.ucsc.edu/

Charmaz, K. (2003). Qualitative interviewing and grounded theory analysis. In J. Holstein \& J. F. Cabrium (Eds.), Inside interviewing: New lenses, new concerns. (pp. 311-330). Thousand Oaks, CA: Sage.

Charmaz, K. (2005). Grounded theory in the 21 ${ }^{\text {st }}$ century: Applications for advancing social justice studies. In Denzin, N. K. \& Lincoln, Y. S. (Eds.), The Sage handbook of qualitative research $3^{\text {rd }}$ edition (pp. 507-535). 
Center on Budget and Policy Priorities. (2012). Policy basics: Introduction to the supplemental nutrition assistance program (SNAP). Retrieved from: http://www.cbpp.org/cms/index.cfm?fa=view\&id=2226

City of Portland Food Policy Council. (2004) Diggable City. Retrieved from: http://www.portlandonline.com/bps/index.cfm?c=42291\&

Coalition for Food Security. (2012). What is community food security? Retrived from: http://www.foodsecurity.org/views cfs faq.html.

Costanza, R. (2010). Personal website. http://www.robertcostanza.org/.

Dekker, P., \& Uslaner, E. M. (2001). Social capital and participation in everyday life. New York: NY. Routledge.

Denzin, N. K., \& Lincoln, Y. S. (2005). The Sage handbook of qualitative research $3^{\text {rd }}$ edition. Thousand Oaks, CA: Sage.

Desmond, D., Grieshop, J., \& Subramaniam, A. (2002). Revisiting garden based learning in basic education: Philosophical roots, historical foundations, best practices and products, impacts, outcomes, and future directions. SDRE Food and Agricultural Organization/United Nations. Rome, Italy. Retrived from: ftp://ftp.fao.org/sd/SDR/SDRE/GBL paper for SD.doc

Dewey, J. (1938). Experience and Education. New York, NY: Touchstone.

Edwards, A.R. (2005). The sustainability revolution: Portrait of a paradigm shift. British Columbia, Canada: New Society.

Elisas J. L., \& Merriam, S. B. (2005). Philosophical foundations of adult education. Malabar, FL: Krieger.

Ferdig, M. A., (2007). Sustainability leadership: Co-creating a sustainable future. Journal of Change Management, 7(1), 25-35.

Fisher, A. (2010). What is food democracy? In Food First: Institute for Food \& Development Policy. Retrieved from: http://www.foodfirst.org/en/node/2868

Fisher, A. (2005). Building the bridge: Linking food banking and community food security. Retrived from: http://www.foodsecurity.org/pubs.html\#foodbank

Flores, H. C. (2006). Food not lawns: How to turn your yard into a garden and your neighborhood into a community. White River Junction, Vermont: Chelsea Green.

Gay, L. R., Mills, G. E., \& Airasian, P. (2009). Educational research: Competences for analysis and applications. Upper Saddle River, NJ: Pearson Education, Inc.

Gaylie, V. (2009). The learning garden: Ecology, teaching and transformation. New York, NY: Peter Lang. 
Glaser, B. G., \& Strauss, A. L. (1967). The discovery of grounded theory: Strategies for qualitative research. Hawthorne, N.Y: Aldine de Gruyter.

Goldbard, A. (2006). New creative community: The art of cultural development. Oakland, CA: New Village Press.

Gottlieb, R., \& Joshi, A. (2010). Food justice. Cambridge, MA: MIT Press.

Gruenewald, D. A. (2003). The best of both worlds: A critical pedagogy of place. Educational Researcher. 32(4), pp. 3-12.

Hawken, P. (2007). Blessed Unrest: How the largest movement in the world came into being and why no one saw it coming. New York, NY: Penguin.

Heffner, G. G., Zandee, G. L., \& Schwander, L. (2003). Listening to community voices: Community-based research, a first step in partnership and outreach. Journal of higher education outreach and engagement. 8(1), p. 127.

Heffter, E. (2011, September 24). Survey: Affordability key hurdle to healthier diet. Retrieved from The Seattle Times: http://seattletimes.nwsource.com/html/localnews/2016310037 gotgreen2 $\underline{5 m \cdot h t m l}$

Heifetz, R., \& Laurie, D. (1997). The work of leadership. In Best of HBR, Harvard Business Review. Cambridge, MA: Harvard Business School Publishing Corp.

Helgesen, S. (1990). The female advantage: Women's ways of leadership. New York, NY: Doubleday.

Helgesen, S. (1995). The web of inclusion: A new architecture for building great organizations. New York, NY: Doubleday.

Hemenway, T. (2009). Gaia's Garden: A Guide to Home-scale permaculture. White River Junction: VT.

Hinrichs, C. C., \& Lyson, T. A. (Eds.) (2007). Remaking the north American food system: Strategies for sustainability. Lincoln, NB: University of Nebraska Press.

Holmgren, D. (2002). Permaculture: Principles and pathways beyond sustainability. Victoria, Australia: Holmgren Design Services.

Hondagneu-Sotelo, P. (2010). Cultivating questions for a sociology of gardens. Journal of Contemporary Ethnography. 39(5) pp. 498-516.

Hunger Notes. (2012). Hunger in America: 2012 United States hunger and poverty facts. Retrieved from:

http://www.worldhunger.org/articles/Learn/us hunger facts.htm

Huxta, B. (2009, July). Where hope grows. Organic Gardening Magazine. 56(5), 6466.

Kolasa, K. M., Peery, A., Harris, N.G., \& Shovelin, K. (2001) Food Literacy 
Partners Program: A Strategy To Increase Community Food Literacy. Topics in Clinical Nutrition: Changing the Face of Dietetics. 16(4) pp. 601.

Knapp, C. E. (2005). The "I - Thou" relationship, place-based education, and Aldo Leopold. Journal of Experiential Education, 27(3), 277-285.

Kolb, D. A., Boyatzis, R. E. \& Mainemelis, C. (1999). Experiential Learning: Previous Research and New Directions. Unpublished manuscript. Department of Organizational Behavior, Case Western Reserve University, Cleveland, $\mathrm{OH}$.

Kolb, D. A. (1984). Experiential learning: Experience as the source of learning and development. New Jersey: Prentice-Hall.

LaDuke, W. (2005). Recovering the sacred: The power of naming and claiming. Cambridge, MA: SouthEnd Press.

Lawson, L. J. (2005). City bountiful: A century of community gardening in America. Berkeley, CA: University of California Press.

Lappé, F. M. (2002). Hope's Edge. New York, NY: Penquin.

Leachman, M. (2008). Profiles of hunger \& poverty in Oregon. In 2008 Oregon hunger factors assessment. Portland, Oregon: Oregon Food Bank.

McMichael, P. (2008). Development and social change: A global perspective. Los Angeles, CA: Pine Forge Press.

Minkler, M. (2005). Community-based research partnerships: Challenges and opportunities. Journal of urban health: Bulletin of the New York academy of medicine. 82(2).

Mollison, B. (1988). Permaculture: A design manual. Tyalgum, Australia: Tagari.

Mougeot, L. J. A. (2006). Growing better cities: Urban agriculture for sustainable development. Ottawa, ON, Canada: International Development Research Centre.

Nelson, M. K. (2008) (Ed). Original instructions: Indigenous teachings for a sustainable future. Rochester, VT: Bear \& Company.

Nordahl, D. (2009). Public policy: The new urban agriculture. Washington DC: Island Press.

Oregon Center for Public Policy. (2008, January). Food insecurity and hunger statistics by state. Silverton, Oregon. Retrieved from: http://www.ocpp.org/cgi-bin/display.cgi?page=iss080116hunger

Oregon Food Bank. (2012). Seed to Supper. Retrieved from: www.foodbank.org/ofb services/food programs/learning garden.html

Oregon Food Bank. (2008). Profiles of hunger \& poverty in Oregon: 2008 Oregon hunger factors assessment. Portland, OR: OFB. 
Parajuli, P. (2000). Revisiting Gandhi and Zapata. Course Reader for Gandhi, Zapata, and a New Agrarianism, pp. 35-45. Portland, OR: Portland State University.

Parajuli, P., \& Williams, D. 2002. Towards an environmentalism of the global south: a playful conversation around Mahatma Gandhi. Encounter: Education for Meaning and Social Justice.15(2) pp. 56-70.

Pollan, M. (2008, October 12). Farmer in chief. Retrieved from The New York Times: http://www.nytimes.com/2008/10/12/magazine/12policyt.html? r $=1 \& \mathrm{scp}=1 \& \mathrm{sq}=$ farmer $\% 20 \mathrm{in} \% 20$ chief $\% 20$ $\% 20$ Michael $\% 20$ Pollan\&st $=$ cse

Poppendieck, J. (1998). Want amid plenty: from hunger to inequality. Monthly Review, 50(3), p. 125.

Poppendieck, J. (1998). Sweet charity: Emergency food and the end of entitlement. New York, NY: Penguin.

Poppendieck, J. (2010). Free for all: Fixing school food in America. Berkeley, CA: University of California Press.

Schlosser, E. (2001). Fast food nation: The dark side of the all-American meal. New York: Houghton Mifflin Company.

Sen, A. (1999). Development as freedom. New York, NY: Anchor Books.

Senge, P. (1990). The Fifth Discipline: The art and practice of the learning organization. New York, NY: Currency Doubleday.

Shiva, V. (2005). Earth Democracy: Justice, Sustainability, and Peace. Brooklyn, NY: South End Press.

Skinner, A. E., \& Chi, U. (2011). Does engagement in garden-based activities predict science learning in the garden and academic achievement in at-risk middle school students? Unpublished manuscript. Portland, OR: Portland State University Department of Psychology.

Smith, M. K., (2001). Peter Senge and the learning organization. Infed: Ideas, thinkers, practice. Retrieved from: www.infed.org.

Sobel, D. (2004). Place-based education: Connecting classrooms and communities. Great Barrington, MA: The Orion Society.

Spurlock, M. (2004). Super size me: A film of epic portions. Canada: Kuthbur Pictures.

Subramaniam, A. (2002). Garden-based learning in basic education: A historical review. 4 H Center for Youth Development. Retrieved from: Http://fourhcyd.usdavis.edu.

Tashakkori, A., \& Teddlie, C. (Eds.) (2003). Handbook of mixed methods in social \& behavioral research. Thousand Oaks, CA: Sage. 
UNESCO. (2012). Education for sustainable development. Retrieved from http://www.unesco.org/new/en/education/themes/leading-theinternational-agenda/education-for-sustainable-development/

Ver Ploeg, M., Breneman, V., Farrigan, T., Hamrick, K., Hopkins, D., Kaufman, P., \& Tuckermanty, E. (2009). Access to affordable and nutritious food: Measuring and understanding food deserts and their consequences. USDA Report to Congress. Retrieved from http://www.ers.usda.gov/Publications/AP/AP036/.

USDA. (2012). SNAP Statistics and data. Retrived from: http://www.fns.usda.gov/pd/snapmain.htm

VanderWonde, T. (2008) Voices: Stories about hunger from the Oregon Food Bank Network. Portland, Oregon: Oregon Food Bank.

Williams, D. R., \& Brown, J. D. (2012). Learning gardens and sustainability education: Bringing life to schools and schools to life. New York, NY: Routledge.

Winne, M. (2008). Closing the food gap: Resetting the table in the land of plenty. Boston, MA: Beacon Press.

Winne, M., Hugh, J., \& Fisher, A. (1997). Community food security: A guide to concept, design, \& implementation. Presentation by The Community Food Security Coalition. Retrieved from: www.foodsecurity.org/CFSguidebook1997.PDF

Withers, D. (2010). Community learning garden programs in the Portland area: how do learning gardens help low-income families access fresh locally-grown foods? Portland State University McNair Journal 4 pp. 71-113.

Wolcott, H.F. (2009). Writing up qualitative research. Thousand Oaks, CA: Sage.

Woodhouse, J., \& Knapp, C. E. (2000). Place-based curriculum and instruction: Outdoor and environmental education approaches. Eric Digest. 


\section{APPENDIX A \\ OREGON FOOD BANK LEARNING GARDEN SURVEY}

Workshop Title: Date(w/year):

Please respond to the following statements with:

\section{1 = disagree, $\mathbf{2}$ = maybe, 3 = agree}

1. This workshop taught me something that I will be able to use in my garden.

$\begin{array}{lll}1 & 2 & 3\end{array}$

2. This workshop has encouraged me to plant a garden. $\begin{array}{lll}1 & 2 & 3\end{array}$

3. I grow some of my own produce. 1123

4. I have gained enough experience to grow some of my own fruits and vegetables.

5. I would like more gardening training. $\quad 1 \quad 2 \quad 3$

6. Within the past two years I have grown some food. $\begin{array}{lll}1 & 2 & 3\end{array}$

7. I purchase more fresh fruits and vegetables. $\quad 1 \quad 2 \quad 3$

8. I currently use a community garden space. 1423

9. I have a garden in my yard $\quad \begin{array}{llll}1 & 2 & 3\end{array}$

10. I volunteer at Oregon Food Bank's Learning Gardens $\quad 1 \quad 2 \quad 3$

Circle or check boxes.

11. How often do you eat fresh fruits and vegetables? (Circle most often)

3 times per day $\quad 1$ time per day 5 times per week

1 time per week

12. What additional things do you need to grow a garden?

(Check all that apply)

a Seeds

- Garden Advice

- Labor in Garden

- Access to how-to Garden books

- Garden space

a Help putting in your garden

- Gardening Tools

- Money to buy garden supplies

a Other 
13. What prevents you from obtaining fresh fruits and vegetables or growing your own?

(Check all that apply)

a Cost

- Availability

- Garden space

a No time to garden

14. What would you recommend changing or adding to improve these workshops?

15. Please share a story about your gardening as a result of this workshop?

16. Do you need more information or advice to grow a garden? If yes, please explain

17. Where do you get your gardening questions answered?

\section{Income Information - Learning Garden}

Oregon Food Bank's Learning Garden programs work to address the root causes of hunger through increased nutrition, community food security and self-reliance in our community. In order to make sure our programs are effectively reaching those who may be in need, we would like to find out how many volunteers and educational participants earn less than $200 \%$ of the Federal Poverty Level. This 
form is optional, but your participation will help us refine our programs and outreach efforts. This information will be kept completely confidential. Simply find the number of people in your household and determine whether you make more or less than the income listed. Check the appropriate box below.

My family earns less than the amount listed below

My family makes more than the amount listed below

\begin{tabular}{|c|c|c|}
\hline $\begin{array}{l}\text { Number of People in } \\
\text { Household }\end{array}$ & $\begin{array}{l}\text { Combined Annual } \\
\text { Income }\end{array}$ & $\begin{array}{l}\text { Combined Monthly } \\
\text { Income }\end{array}$ \\
\hline 1 & $\$ 21,660$ & $\$ 1805$ \\
\hline 2 & $\$ 29,140$ & $\$ 2428$ \\
\hline 3 & $\$ 36,620$ & $\$ 3052$ \\
\hline 4 & $\$ 44,100$ & $\$ 3675$ \\
\hline 5 & $\$ 51,580$ & $\$ 4298$ \\
\hline 6 & $\$ 59,060$ & $\$ 4922$ \\
\hline 7 & $\$ 66,540$ & $\$ 5545$ \\
\hline 8 & $\$ 74,020$ & $\$ 6168$ \\
\hline
\end{tabular}




\section{APPENDIX B}

\section{SEED TO SUPPER PARTICIPANT INTERVIEW QUESTIONS}

1. As a result of taking a learning garden workshop, have you gained enough experience to grow some of your own fruits and vegetables. If yes, explain. If no, why.

2. As a result of taking a learning garden workshop, do you eat more fresh-grown produce? If yes, what kinds, did you grow them or purchase them?

3. Were you growing fruits and vegetables before the workshop $\mathrm{Y} / \mathrm{N}$, or after the workshop Y/N.

4. How has this workshop changed the kind of food you eat?

5. Where do you purchase or obtain most of your fresh produce?

Farmer's Market Grocery Store Your or your neighbor's garden Food For Less Food Pantry CSA

Oregon Food Bank Food Co-op Natural Food Store

Other

6. What influences your decision to buy fruits and vegetables?

Cost Availability Convenience Nutritional Value Taste Transportation

Other

7. Why do you grow your own fruits and vegetables?

Taste Availability Cost Do not grow my own produce Other

8. What would you recommend changing or adding to improve these workshops?

9. Please share a story about your gardening or meal experience as a result of this workshop?

10. Do you need more information or advice to grow a garden?

11.Where do you get your gardening questions answered? 
12. Have you taken other gardening classes? If yes, which ones.

13. Do you work outside of the home?

14. Is there anything you would like to share about the Seed to Supper Program experience? 